Division of Geological \& Geophysical Surveys

PRELIMINARY INTERPRETIVE REPORT 2005-4

SEDIMENTOLOGY, STRATIGRAPHY, AND HYDROCARBON RESERVOIR-SOURCE ROCK POTENTIAL, USING SURFACE AND SUBSURFACE DATA, OF TERTIARY AND MESOZOIC STRATA, BRISTOL BAY BASIN AND ALASKA PENINSULA

by

Emily S. Finzel, Rocky R. Reifenstuhl, Paul L. Decker, and Kenneth D. Ridgway

July 2005

THIS REPORT HAS NOT BEEN REVIEWED FOR TECHNICAL CONTENT (EXCEPT AS NOTED IN TEXT) OR FOR CONFORMITY TO THE EDITORIAL STANDARDS OF DGGS.

Released by

STATE OF ALASKA

DEPARTMENT OF NATURAL RESOURCES

Division of Geological \& Geophysical Surveys

3354 Colleg Rd.

Fairbanks, Alaska 99709-3707

$\$ 7.00$ 



\section{Table of Contents}

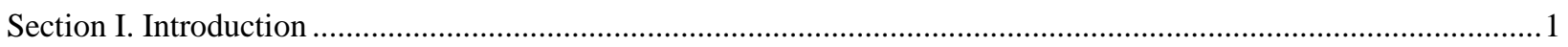

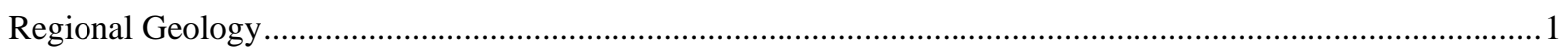

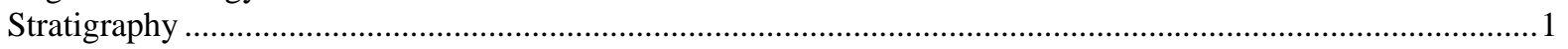

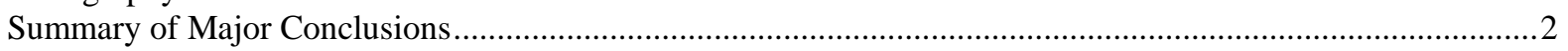

Section II. New Petrophysics and Organic Geochemistry from Outcrop and Wells ..................................................... 8

Section III. Sedimentology, Stratigraphy \& Reservoir Characterization........................................................................18

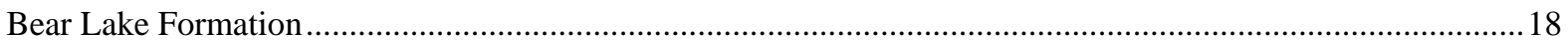

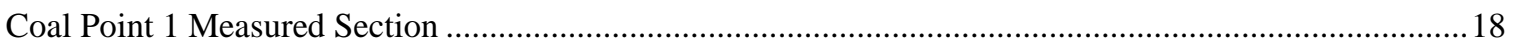

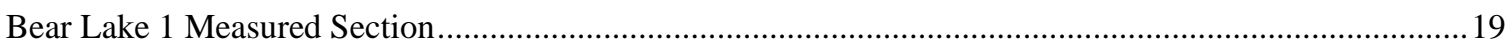

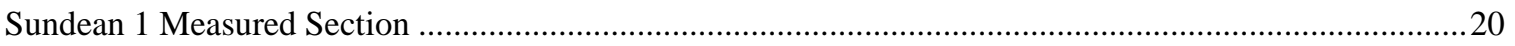

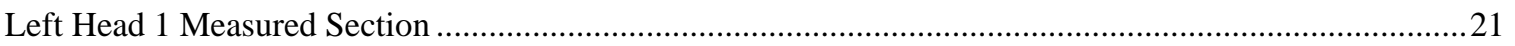

Milky River Formation............................................................................................................................ 22

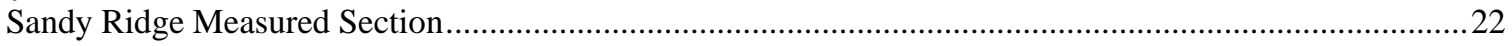

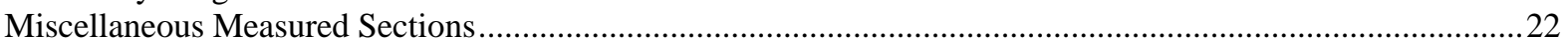

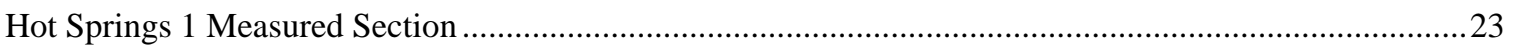

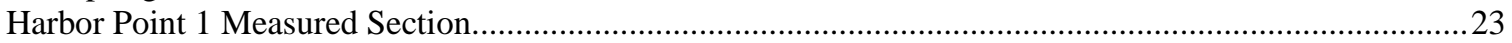

Section IV. Preliminary Subsurface Interpretations of the Bristol Bay/North Aleutian Basin and

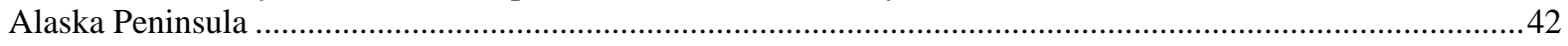

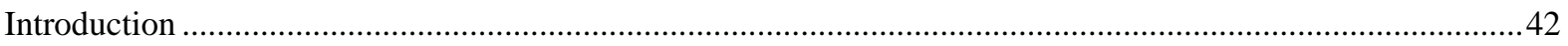

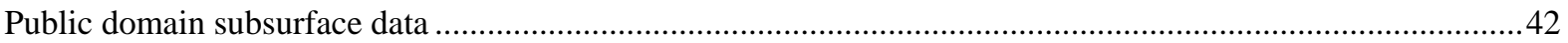

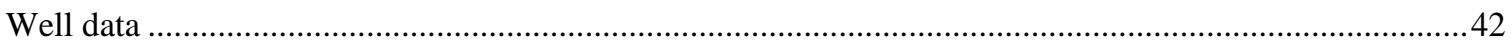

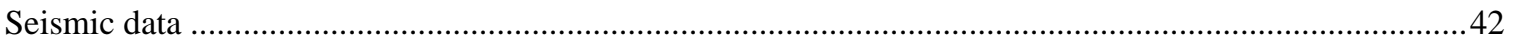

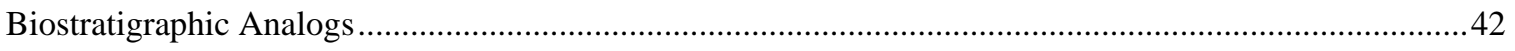

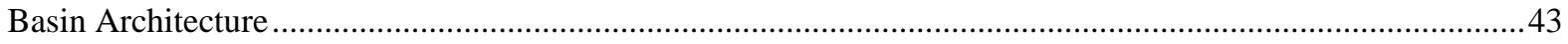

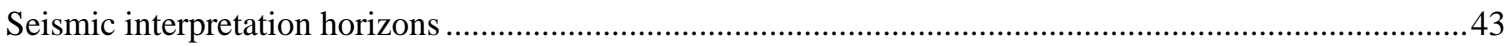

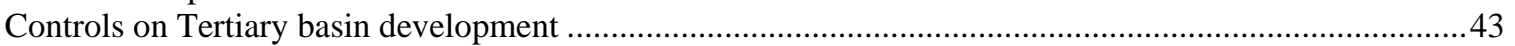

Southwestern Bristol Bay basin margin, Black Hills Uplift, and Northern Amak basin.................................44

Southeastern Bristol Bay basin margin, Alaska Peninsula lowlands..........................................................45

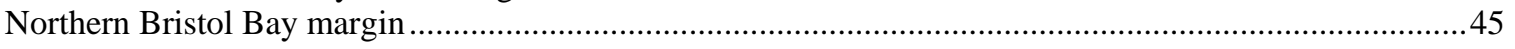

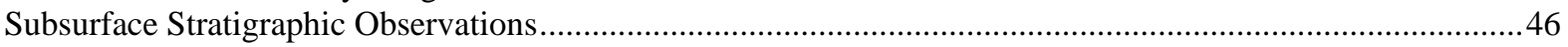

Exploration significance of the Bear Lake-Milky River unconformity .........................................................46

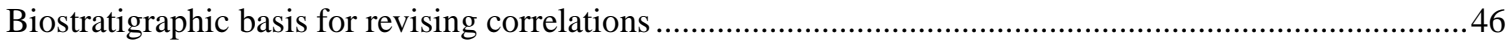

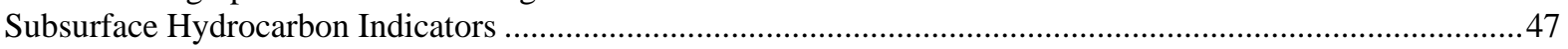

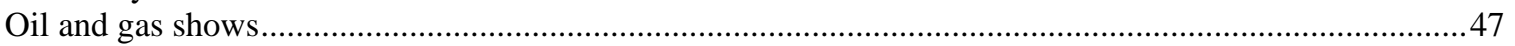

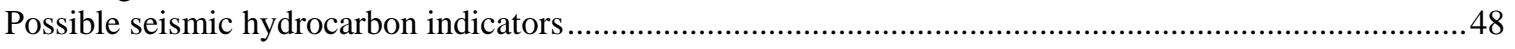

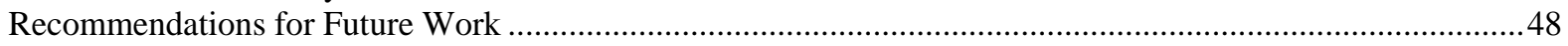

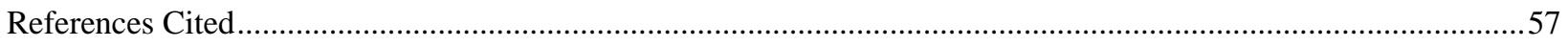

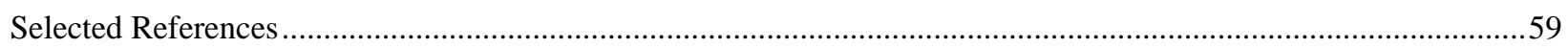





\title{
Sedimentology, stratigraphy, and hydrocarbon reservoir-source rock potential, using surface and subsurface data, of Tertiary and Mesozoic strata, Bristol Bay Basin and Alaska Peninsula
}

\author{
By Emily S. Finzel (emily_finzel@dnr.state.ak.us ${ }^{1}$ ), Rocky R. Reifenstuhl ${ }^{1}$, Paul L. Decker ${ }^{2}$, and Kenneth D. Ridgway ${ }^{3}$
}

\section{Section I. Introduction}

The Alaska Division of Geological \& Geophysical Surveys (DGGS), in collaboration with the Alaska Division of Oil \& Gas (DOG), Purdue University, and the University of Alaska Fairbanks, is engaged in an inprogress study of the hydrocarbon and reservoir potential of the Bristol Bay basin. In order to aid in the evaluation of the subsurface geology of Tertiary units in this basin, surface geological studies were conducted along the coast and mountains of the central Alaska Peninsula during the second phase of the 2004 field season (August 23 to September 2, 2004). The investigations included a study of the depositional environment of the Miocene Bear Lake and the Pliocene Milky River formations in the Port Moller, Herendeen Bay, and Bear Lake areas (fig. 1.1), and collection of samples for porosity, permeability, micropaleontologic, megapaleontologic, organic geochemical, and thermal maturity analyses. An initial report summarizing both the first (May 24 to June 4, 2004) and second phases of the 2004 field season, including preliminary interpretation of analytical results, was issued as a peer-reviewed report by DGGS titled, "Bristol Bay and Alaska Peninsula 2004: Fieldwork and sample analyses compilation report" (Reifenstuhl and others, 2005). Other reports related to this project that address Bristol Bay geology include: Reifenstuhl and others (2004), Blodgett (2005), and White (2005).

Subsurface studies utilizing publicly available seismic data, electric well log data, and micropaleontologic analysis of core are being used to constrain the subsurface geometries of the Mesozoic and Tertiary units. DOG purchased subsurface micropaleontologic data from 11 wells on the northwest Alaska Peninsula from Micropaleo Consultants, Inc. Micropaleo Consultants interpreted the data and, in combination with the electric well logs, developed biostratigraphic cross sections for the southeastern margin of the Bristol Bay basin.

Field operations have been funded by the U.S. Department of Energy through the Arctic Energy Technology Development Laboratory at the University of Alaska Fairbanks, by DGGS, and by DOG. Participating geologists are: Rocky Reifenstuhl (DGGS; project leader), Emily Finzel (DGGS), Ken Ridgway (Purdue University), Paul Decker (DOG), Robert Blodgett (consulting megafossil paleontologist), Mark Myers (DOG), and Paul McCarthy (University of Alaska Fairbanks). Surface micropaleontological analysis was performed by James White (Geological Survey of Canada). Peer review was completed by Paige Peapples (DGGS).

\section{Regional Geology}

The Bristol Bay Basin is a Late Mesozoic to early Cenozoic feature that developed after the accretion of terranes that formed the Alaska Peninsula at the end of the Mesozoic (Marlow and others, 1994). The basin is a sediment-filled structural depression that lies north of the Alaska Peninsula (fig. 1.2). The axis trends northeast and most of the basin lies offshore beneath the Bering Sea shelf. Cenozoic deposits constitute most of the fill, and are more than 6,000 $\mathrm{m}$ thick in the southeastern Bristol Bay basin. The basin is asymmetrical with a gently dipping northwest flank and a steeply dipping southeast flank. It is bound to the northeast by highly deformed, locally intruded, metamorphosed Paleozoic and Mesozoic rocks (Hatten, 1971), and to the southeast by the offshore extension of the Black Hills Uplift (Marlow and others, 1994). The southern boundary of the basin is mostly composed of Mesozoic and Cenozoic volcanic and plutonic basement rocks that form the core of the Alaska Peninsula (McLean, 1977). According to geophysical data, the northern boundary of the basin, which lies beneath the Bering Sea shelf, may be formed by Mesozoic sedimentary, igneous, and metamorphic rocks (Marlow and others, 1994).

\section{Stratigraphy}

The Mesozoic section forms the backbone of the Alaska Peninsula and is exposed mostly on the southeast side of the peninsula (Detterman and others, 1996; figs. 1.2 and 1.3). The Upper Triassic Kamishak Formation is composed of about $800 \mathrm{~m}$ of limestone and lesser volcanic rocks. The Lower Jurassic Talkeetna Formation consists of about $400 \mathrm{~m}$ of tuffaceous sandstone and tuff. The overlying Kialagvik Formation (Middle Jurassic) is composed

\footnotetext{
${ }^{1}$ Division of Geological \& Geophysical Surveys, 3354 College Road, Fairbanks, AK 99709-3707

${ }^{2}$ Division of Oil \& Gas, 550 W. 7th Avenue, Suite 800, Anchorage, AK 99501-8938

3 Department of Earth \& Atmospheric Sciences, Purdue University, Civil Engineering Building, 550 Stadium Mall Drive, West Lafayette, IN 47907-2051
} 
of a few hundred feet of sandstone, shale, and conglomerate. The Middle Jurassic Shelikof Formation is an approximately 1,400-m-thick fine-grained volcaniclastic unit deposited in deep to shallow water. The most widespread Mesozoic formation on the peninsula is the approximately 1,800-m-thick Upper Jurassic Naknek Formation. The Naknek Formation has been subdivided into five members, which are, from oldest to youngest: the Chisik Conglomerate Member, the Northeast Creek Sandstone Member, the Snug Harbor Siltstone Member, the Indecision Creek Sandstone Member, and the Katolinat Conglomerate Member. Cretaceous units include sandstones, siltstones, and shales of the Lower Cretaceous Staniukovich Formation, calcareous sandstones of the Lower Cretaceous Herendeen Formation, sandstones and siltstones of the Upper Cretaceous Chignik Formation, and siltstones and shales of the Upper Cretaceous Hoodoo Formation.

The Tertiary section on the Alaska Peninsula consists of mainly sedimentary rocks, with varying amounts of volcaniclastics that are both marine and nonmarine (Detterman and others, 1996) (figs. 1.2 and 1.3). The Tolstoi and Bear Lake formations are exceptions that are primarily composed of nonvolcanic sediments. The oldest Tertiary deposit is the Paleocene to Eocene Tolstoi Formation, which was deposited by onlap onto the older Mesozoic rocks. The Eocene to Oligocene Stepovak Formation and Meshik Volcanics intertongue along the southwest side of the peninsula. The Stepovak Formation consists of about 2,000 m of volcaniclastic siltstones and sandstones. The Early Miocene Unga Formation exposures are limited to the Unga Island area, and is dominanted by subaerial deposits. The late Miocene Bear Lake and Pliocene Milky River formations form spectacular exposures along the coast and mountains of the central Alaska Peninsula. The Bear Lake Formation is about 1,000 m thick onshore and up to 2,360 $\mathrm{m}$ thick in offshore boreholes (Detterman and others, 1996). The Milky River Formation is $465 \mathrm{~m}$ thick at its type locality onshore, and upwards of 1,000 m thick in offshore boreholes (Detterman and others, 1996).

\section{Summary of Major Conclusions}

The modern approach to basin evaluation typically uses a standard format events chart to summarize the geologic ages and timing relationships of the critical components of the petroleum system. A modified events chart has been prepared for the Alaska Peninsula (fig. 1.4) that reflects our current understanding of the region's complex depositional, thermal, and tectonic history. This chart includes considerable uncertainty, and is generalized to account for variations that may occur over the region to be offered in an areawide lease sale scheduled in October 2005.

Mesozoic source rocks include the Triassic Kamishak and Jurassic Kialagvik formations, both containing oilprone marine kerogen, and Cretaceous Chignik Formation, whose coals are a possible source of either thermogenic or biogenic gas. Paleocene to Miocene age coals and non-marine shales of the Tolstoi, Stepovak, and Bear Lake formations contain mostly gas-prone kerogen, though both geochemical and mudlog data demonstrate at least some are capable of generating a certain amount of light oil or condensate. Tertiary coals are also potential sources of biogenic methane. Possible Mesozoic reservoirs include sandstones and conglomerates of the Jurassic Naknek and Cretaceous Herendeen formations. In the Tertiary, reservoir quality sands are most likely to occur in the Tolstoi, Bear Lake, Unga equivalent, and Milky River formations. No regional seals have been identified to date, however, marine shales of the lower Neocomian Staniukovich Formation may have been widely distributed prior to midCretaceous and younger erosional events, and may still serve as a seal for some Naknek Formation reservoirs. Relatively thin, locally distributed, nonmarine to shallow marine siltstones and mudstones are considered probable seals in the Chignik, Tolstoi, Stepovak, and Bear Lake formations, similar to the intra-formational seals of many Cook Inlet fields, which can serve as an analog to this area. The Cook Inlet system has a similar age stratigraphy, source rock character, and structural timing as the Alaska Peninsula area, and is a viable, producing system.

Beyond the basic stratigraphically defined elements of source, reservoir, and seal units, the events chart becomes more interpretive. Our understanding of trap formation is too limited by insufficient knowledge of subsurface structure and stratigraphy to predict which deformational episodes might have created closed structures, and which units may contain stratigraphic traps. Figure 1.4 represents the general timing of tectonic events by the erosional gaps at unconformities, but it is likely that deformation of various types continued along this active margin through much of Tertiary time.

Most petroleum system events charts include an additional row to identify the "critical moment" in basin evolution, usually the age of peak generation, when reservoirs, seals, and traps must all be in place to accumulate migrating hydrocarbons. The so-called "preservation time" is the time between the critical moment and the present, during which these accumulations must remain intact. So far, it has not been possible to single out a critical moment or the ensuing preservation time for the region of the areawide sale on the Alaska Peninsula, so these items are not depicted in figure 1.4. There are several reasons for this, all of which relate to the timing of hydrocarbon generation and trap formation: (1) different portions of the sale area may contain multiple source rock units of widely varying ages, kerogen type, and conversion kinetics, whose subsurface distribution is largely unknown, (2) these multiple 
source rocks' thermal history is poorly defined, but almost certainly includes strongly time variant and spatially variant heat flow, with locally significant magmatic heating in addition to normal maturation by depositional burial, (3) traps may have been either created or destroyed in different portions of the sale area at nearly any time in the deformational continuum inferred above, and (4) the abundant coals are likely to source biogenic gas, but there is substantial uncertainty regarding the timing and amount of uplift depressurization of these coals to facilitate expulsion and migration of biogenic gas to adjacent reservoir sands. Only with much additional data and sophisticated basin modeling will these uncertainties be resolved.

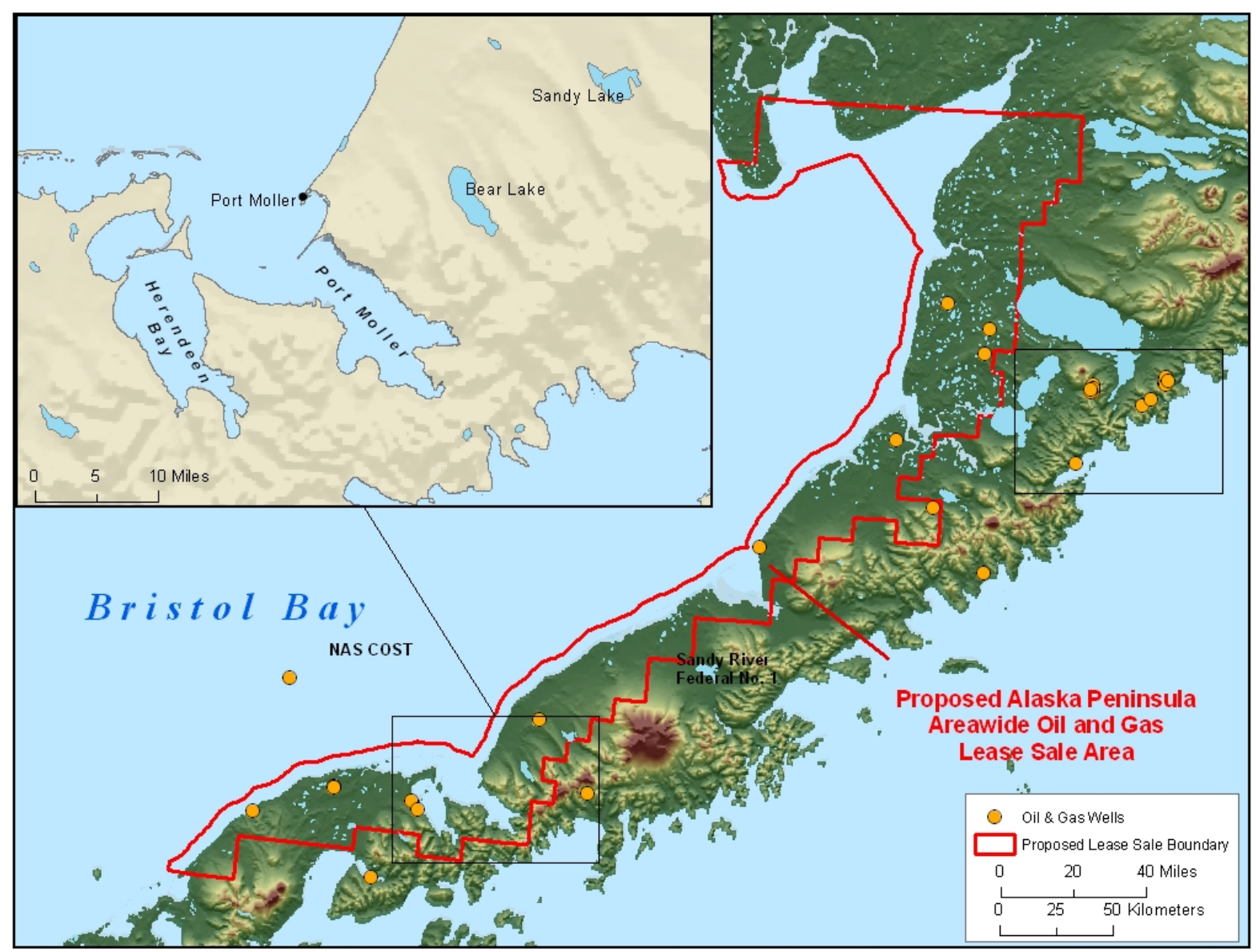

Figure 1.1. Shaded relief map of the Alaska Peninsula area, showing oil and gas wells, the proposed Alaska Peninsula areawide oil and gas lease sale area, and the study areas. 


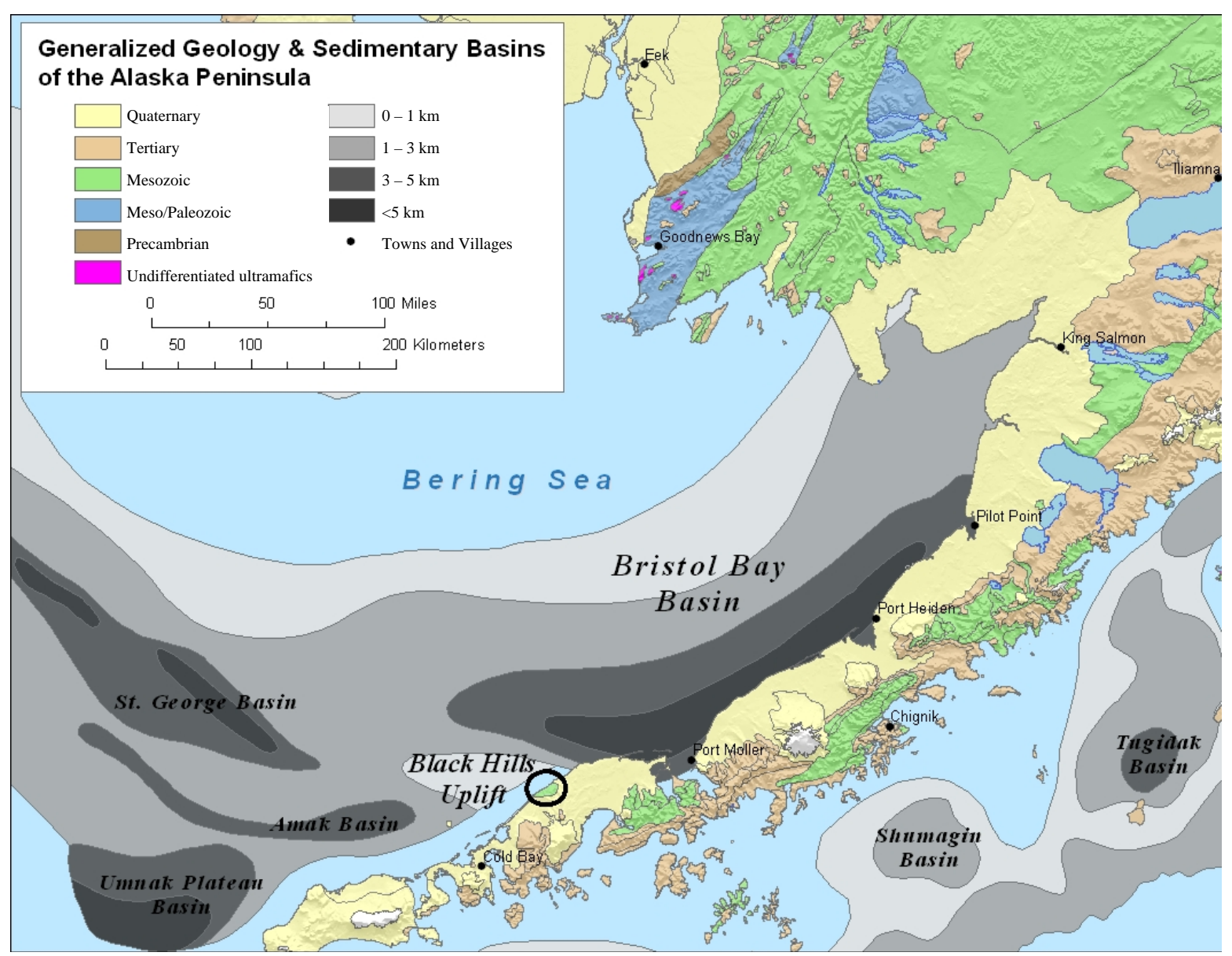

Figure 1.2. Generalized geology (modified from Beikman, 1980) of the Alaska Peninsula area, showing sedimentary basin thickness (courtesy of DOG) for Bristol Bay and surrounding basins. 


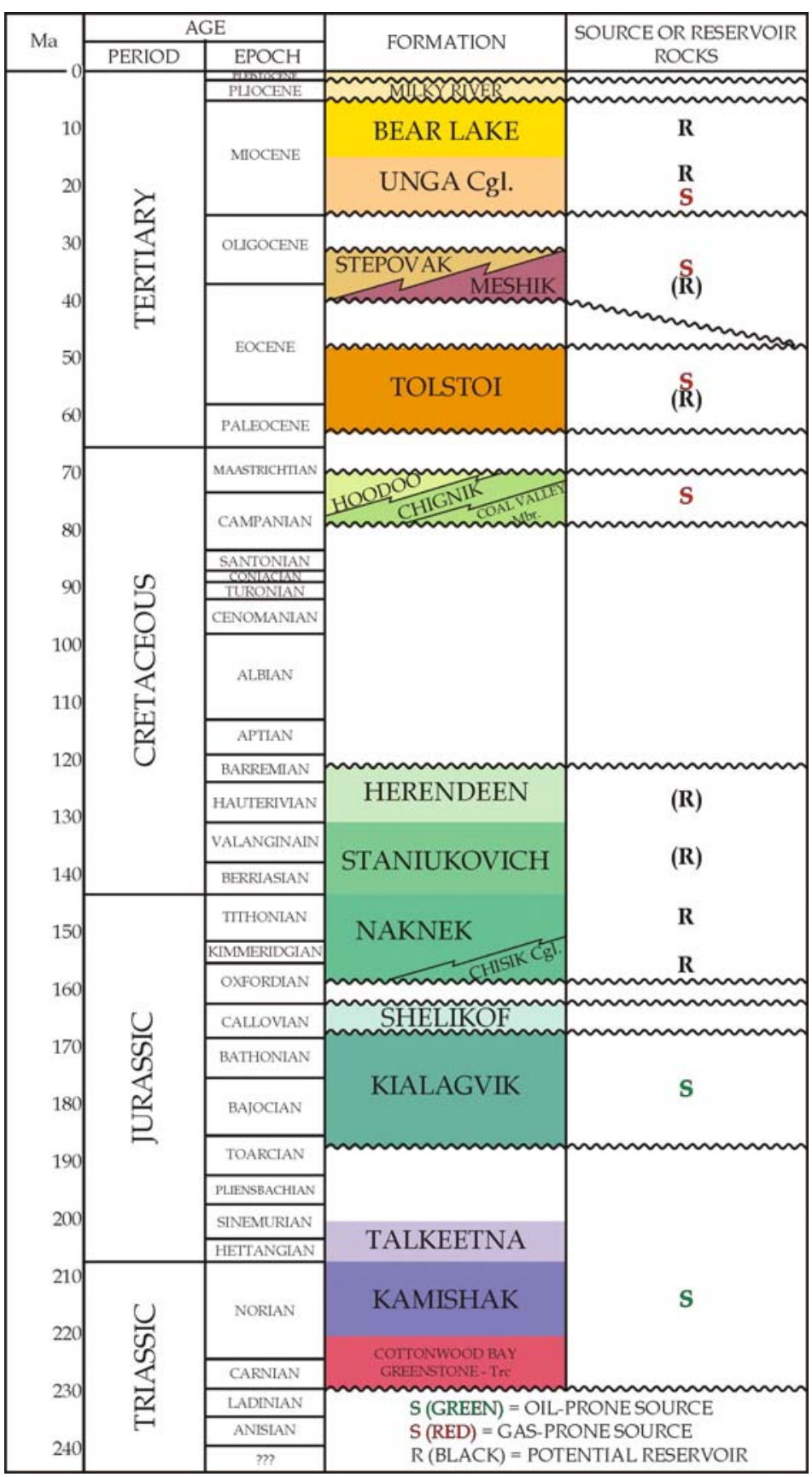

Figure 1.3. Composite stratigraphic column of the Bristol Bay and Alaska Peninsula areas. (Modified from Burk, 1965 and Detterman and others, 1996) 


\begin{tabular}{|c|c|c|c|c|c|c|c|c|c|c|c|c|c|c|c|}
\hline \multicolumn{8}{|c|}{ MESOZOIC } & \multicolumn{6}{|c|}{ TERTIARY } & \multirow{3}{*}{ 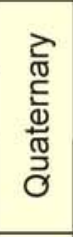 } & \multirow{3}{*}{$\begin{array}{l}\text { Geologic Time } \\
\text { Scale } \\
\text { Petroleum } \\
\text { System Events }\end{array}$} \\
\hline \multicolumn{3}{|c|}{ Triassic } & \multicolumn{3}{|c|}{ Jurassic } & \multicolumn{2}{|c|}{ Cretaceous } & \multirow{2}{*}{ Paleocene } & \multirow{2}{*}{ Eocene } & \multirow{2}{*}{\multicolumn{2}{|c|}{ Oligocene }} & \multirow{2}{*}{ Miocene } & \multirow{2}{*}{ Pliocene } & & \\
\hline \multirow[t]{3}{*}{$E$} & $M$ & L & $E$ & $M$ & L & $E$ & $\mathrm{~L}$ & & & & & & & & \\
\hline & amis & & & $\begin{array}{l}\text { alag } \\
\text { ale }\end{array}$ & & & $\begin{array}{r}\text { Chig } \\
\text { co }\end{array}$ & & $\begin{array}{l}\text { Tolstoi } \\
\text { coal \& } \\
\text { shale }\end{array}$ & $\begin{array}{l}\text { Stepovak } \\
\text { shale }\end{array}$ & & $\begin{array}{l}\text { Bear Lake } \\
\text { coal \& } \\
\text { shale }\end{array}$ & & & Source Rock \\
\hline & & & & $\begin{array}{r}\mathrm{Nak} \\
\text { ands }\end{array}$ & & $\begin{array}{l}\text { Here } \\
\text { sanc }\end{array}$ & & & $\begin{array}{l}\text { Tolstoi } \\
\text { andstone }\end{array}$ & & $\begin{array}{l}\text { Unga (e } \\
\text { sandstc }\end{array}$ & $\begin{array}{l}\text { q.) Bear Lake } \\
\text { one sandstone }\end{array}$ & $\begin{array}{l}\text { Milky River } \\
\text { sandstone }\end{array}$ & & Reservoir Rock \\
\hline \multicolumn{6}{|c|}{$\begin{array}{l}\text { No regionally extensive seals } \\
\text { have been found to date. Local, } \\
\text { intraformational seals probably } \\
\text { exist in these formations. }\end{array}$} & & & $\begin{array}{l}\text { nik } \\
\text { nation }\end{array}$ & $\begin{array}{l}\text { Tolstoi } \\
\text { cormation }\end{array}$ & $\begin{array}{l}\text { Stepovak } \\
\text { Formation }\end{array}$ & & $\begin{array}{l}\text { Bear Lake } \\
\text { Formation }\end{array}$ & $\begin{array}{l}\text { Milky River } \\
\text { Formation } \\
\text { (basal) }\end{array}$ & & Seal Rock \\
\hline & & & & & & & & & & & & & & & Overburden Rock \\
\hline \multirow{2}{*}{\multicolumn{8}{|c|}{$\begin{array}{l}\text { Tectonic events are probably more } \\
\text { continuous throughout Tertiary time } \\
\text { than the major unconformity gaps } \\
\text { shown here. } \\
\begin{array}{l}\text { Generation of known Mesozoic } \\
\text { oils speculatively linked to magmatic } \\
\text { heating (Hudson, 1986) during } \\
\text { Late Cretaceous (Magoon and Anders, 1992). }\end{array} \\
\end{array}$}} & & & & & & & & $\begin{array}{l}\text { Trap Formation } \\
\text { (Tectonic Events) }\end{array}$ \\
\hline & & & & & & & & $\begin{array}{l}\text { Timing } \\
s \\
\text { thermo } \\
b\end{array}$ & $\begin{array}{l}\text { of onset of gene } \\
\text { sourced oil shov } \\
\text { ggenic gas is not } \\
\text { out likely continu }\end{array}$ & $\begin{array}{l}\text { eration or Te } \\
\text { ws and asso } \\
\text { t well constr } \\
\text { ues to the pr }\end{array}$ & $\begin{array}{l}\text { liary- } \\
\text { ciated } \\
\text { ained, } \\
\text { esent. }\end{array}$ & & & & $\begin{array}{l}\text { Generation-Migration- } \\
\text { Accumulation }\end{array}$ \\
\hline
\end{tabular}

Figure 1.4. Events chart summarizing the geologic ages and timing relationships of the critical components of the Bristol Bay basin petroleum system. 


\section{Section II. New Petrophysics and Organic Geochemistry from Outcrop and Wells}

Petrophysics and rock geochemistry presented here comprise 2004 outcrop data (figs. 2.1, 2.2, and table 2.1), new analyses from drill core data (figs. 2.2, 2.3, 2.4, 2.6, and table 2.2), and compiled public petrophysics from four Bristol Bay and Alaska Peninsula wells (North Aleutian COST, Becharof, Sandy River, and Port Heiden; fig. 2.5). The new drill core data were collected during 2005 from the North Aleutian COST well core material (courtesy of ConocoPhillips), and from the Becharof State \#1 well (from the Alaska Geologic Materials Center). The publicly available drill core petrophysics (fig. 2.5) are from the Alaska Division of Oil \& Gas (DOG) archives, except the North Aleutian COST well data shown in figure 2.5, which is from the U.S. Minerals Management COST well report (Turner, 1988).

Outcrop samples are all from the Middle Jurassic through Pliocene part of the stratigraphic section (table 2.1 and figs. 2.1, 2.2). Mesozoic samples from the southeast side of the Alaska Peninsula are from the Kialagvik (Middle Jurassic), Shelikof (Middle Jurassic), and Naknek (Upper Jurassic) formations. Mesozoic samples from the greater Port Moller area are from the Herendeen Limestone (Lower Cretaceous) and the Coal Valley Member of the Chignik Formation (Upper Cretaceous). Tertiary outcrop samples from the greater Port Moller area include the Tolstoi (Eocene), Stepovak (Oligocene), Bear Lake (Miocene), and Milky River (Pliocene) formations. Specific locations and details concerning these samples are in Reifenstuhl and others (2005). Megafossil information is addressed in Blodgett (2005).

Oil seeps that occur on the southeast side of the Alaska Peninsula have been sampled extensively and typically flow from Shelikof Formation strata of Middle Jurassic age. The Triassic Kamishak Formation is the main hydrocarbon source rock based on geochemical analyses; one Kamishak Formation limestone yielded 2.38 percent total organic carbon (Reifenstuhl and others, 2005).

Hydrocarbon shows within the Mesozoic section from selected wells on the Alaska Peninsula are summarized below. These hydrocarbon shows are based on publicly available well logs: Oil stains in Cathedral River \#1, dead oil and stain in Koniag \#1 (Naknek Formation), oil stains in Cathedral River \#1 (Shelikof Formation), oil staining in Bear Creek \#1, Wide Bay \#1, Grammar \#1, Cathedral River \#1 (Kialagvik), dead oil in Bear Creek \#1, oil stains in Wide Bay \#1, Cathedral River \#1 (“Talkeetna Formation,” Bidarka Formation of Kellum, 1945), solid hydrocarbons in Bear Creek \#1 (Kamishak Formation).

Table 2.1 and figure 2.1 show the porosity and permeability analyses of 81 outcrop samples. Figure 2.1 summarizes the petrophysical analyses for nine rock units that range from Pliocene to Middle Jurassic. The Pliocene Milky River Formation samples from the Port Moller area have the best reservoir quality, followed by the Chisik Member of the Naknek Formation, and the Bear Lake Formation. About 30 percent of the 81 samples have permeability greater than 0.10 millidarcies with porosities in the 5 to 15 percent range. Despite poor permeability ( $<0.10$ millidarcy), these rocks can be considered viable gas reservoirs. It's important to note that several outcrops of the Chisik Conglomerate Member of the basal Naknek Formation, the Bear Lake Formation, and the Milky River Formation were too unconsolidated to process for petrophysical analyses. Considering that the Bear Lake Formation is expected to be the reservoir in many published hydrocarbon play models, this inability to collect poorly cemented samples is an important formation aspect that these data alone do not convey.

Approximately half of the samples are from the Mesozoic section. Mesozoic samples are uniformly low in both porosity and permeability, with the exception of four samples from the Chisik Member of the lower Naknek Formation. These Mesozoic rock units were sampled in an effort to obtain a more complete petrophysical outline of the entire stratigraphic succession on the Alaska Peninsula. The majority of the sampled intervals were never considered as potential reservoir targets. Rather, they were the focus of source rock potential or depositional environment studies, and outcrop petrophysics samples were collected for comprehensiveness only. The porosity and permeability values are quite low for two of the three Middle and Late Jurassic units (Kialagvik Formation, Shelikof Formation, and for some of the Naknek Formation). When considering all samples, only 10 percent have more than one millidarcy permeability, and these have corresponding porosity values ranging from 5 to 37 percent.

Figure 2.2 is a plot of vitrinite reflectance (Ro) analysis for 30 outcrop samples, and 16 drill core samples from the NAS COST well. The outcrop samples are from the following formations: Bear Lake, Tolstoi, Chignik, and Naknek. Of the 16 drill core samples, two are from the Eocene-Oligocene Stepovak Formation and range in depth from 8,056 to 9,264 feet. The remaining 14 core samples are from the Paleocene-Eocene Tolstoi Formation and range in depth from 10,729 to 16,718 feet. Seventeen of the Bear Lake Formation outcrop samples plot in the $>0.6$ Ro range. Above 0.6 Ro is considered to be "mature" for hydrocarbon generation. Several of the Bear Lake Formation outcrop Ro values are approximately 0.9 , which is within the gas generation range for humic organic matter. Ten of the Tolstoi Formation drill core samples lie between 0.6 and 1.0 Ro and are well within the gas generation range for humic organic matter. Seven of these Tolstoi Formation analyses have also yielded hydrogen index values of greater than 200 (fig. 2.6). This places them toward the type two kerogen- and oil-prone fields. 
Figure 2.3 is a porosity and permeability plot of 14 samples from the Becharof State \#1 well. The six Bear Lake Formation samples range from 38 to 54 percent porosity and 30 to 800 millidarcies. The Bear Lake Formation drill core rock yielded substantially higher porosity and permeability values relative to our outcrop samples. These subsurface data indicate good reservoir potential for the Bear Lake Formation in the Becharof well. The eight Stepovak Formation samples range from 3 to 9 percent porosity and 0.002 to 0.4 millidarcies. The petrophysical data for the Stepovak Formation in the Becharof State \#1 are substantially lower than values for the Stepovak Formation samples from the NAS COST well (figs. 2.4 and 2.5). The low permeability may be due to extensive pore-clogging alteration products from volcanic components. Future detailed petrographic analyses will address these highly variable petrophysical data.

Figure 2.4 is a plot of the North Aleutian Shelf COST well porosity and permeability analyses. The 11 drill core samples range in depth from 3,393 to 9,957 feet. The COST well reached a completion depth of 17,155 feet in 1983 and bottomed in lower Tertiary strata. The Bear Lake Formation samples from the COST well range in depth from 3,393 to 4,198 feet, and the Stepovak Formation samples range in depth from 5,234 to 9,957 feet. When these subsurface analyses (figs.e 2.4 and 2.5) are compared with the outcrop sample analyses (fig. 2.1; table 2.1), the bimodal distribution of relatively low outcrop values versus relatively high well data becomes evident. The petrologic control on this disparity has not yet been investigated in detail. Our detailed petrographic point counting, cement typing, cement timing, and provenance studies will address these important reservoir characterization issues.

Figure 2.5 is a plot of porosity and permeability data from four Alaska Peninsula wells. Also plotted are the outcrop samples collected during 2004 fieldwork. Notably, the Bear Lake Formation subsurface samples show one to two orders of magnitude higher permeability, and 10 to 15 percent higher porosity relative to the outcrop collections. On figure 2.5, the very highest values from both outcrop and wells samples are from the Pliocene Milky River Formation, which in most play models is too high in the stratigraphic section, not buried deeply enough, and lacks a demonstrated seal. In figure 2.5, the upper portion of all four wells is Milky River Formation. However, Port Heiden \#1 has more than 4,500 feet of Bear Lake Formation and bottomed at 15,015 feet in Eocene strata. Likewise, the Sandy River \#1 well included over 5,000 feet of pre-Miocene strata, 1,500 feet of Bear Lake Formation, and continued to 13,068 feet in Oligocene and Eocene strata. The NAS COST well entered the Miocene at 3,200 feet, the Oligocene at 4,870 feet, and bottomed at 17,155 in Eocene strata (the above well picks are from a Division of Oil \& Gas report, in preparation, based on micropaleontology performed by Micropaleo Consultants, Inc.). In lower Oligocene and Eocene age strata of the COST well, five gas shows and three oil shows were reported (Turner, 1988).

The low permeability of outcrop samples from the Bear Lake Formation is apparently due to alteration products of locally abundant volcanic rock fragments and consequent pore-clogging clays. These diagenetic processes have reduced the pore connectivity in many samples. Again, the Milky River Formation sample values are the highest, with a maximum of 3,500 millidarcies and 32 percent porosity. Nonetheless, the Pliocene Milky River Formation is relatively high in the stratigraphic section, and in many published hydrocarbon play models is considered a less viable reservoir than the underlying Miocene Bear Lake Formation. Detailed petrography will yield information assessing the controls on the high variability of potential reservoirs. 


\begin{tabular}{|c|c|c|c|c|c|c|c|c|c|c|c|c|c|}
\hline \multicolumn{3}{|c|}{ Porosity } & \multicolumn{2}{|c|}{ Permeability (millidarcies) } & \multicolumn{2}{|c|}{ Grain Density } & \multicolumn{3}{|c|}{ Porosity } & \multicolumn{2}{|c|}{ Permeability (millidarcies) } & \multicolumn{2}{|c|}{ Grain Density } \\
\hline Sample ID & $\%$ & Formation & Klinkenberg & Kair & Probe & $\mathrm{g} / \mathrm{cm}^{3}$ & Sample ID & $\%$ & Formation & Klinkenberg & Kair & Probe & $\mathrm{G} / \mathrm{cm}^{3}$ \\
\hline 04RR140C & 11.7 & Bear Lake & 0.613 & 0.898 & & 2.53 & 04RR11D & 3.9 & Kialagvik & 0.060 & 0.106 & & 2.63 \\
\hline SD1-56 & 8.3 & Bear Lake & 0.003 & 0.010 & & 2.71 & 04TJR08 & 7.4 & Kialagvik & 0.444 & 0.698 & & 2.76 \\
\hline LH1-164 & 4.4 & Bear Lake & 0.005 & 0.013 & & 2.73 & 04DS04B & 4.9 & Kialagvik & ns & ns & 0.021 & 2.70 \\
\hline CP1-138 & 7.5 & Bear Lake & 0.006 & 0.017 & & 2.71 & 04DS09C & 4.8 & Kialagvik & ns & ns & 0.053 & 2.74 \\
\hline SD1-64 & 10.6 & Bear Lake & 0.024 & 0.048 & & 2.69 & O4RR3B & 13.4 & Kialagvik & ns & ns & 0.027 & 2.70 \\
\hline CP1-38 & 6.2 & Bear Lake & 0.027 & 0.053 & & 2.66 & SR2-6 & 35.4 & Milky River & 62.237 & 73.113 & & 2.75 \\
\hline LH1-120 & 8.3 & Bear Lake & 0.032 & 0.061 & & 2.67 & SR1-3.5 & 32.7 & Milky River & 222.139 & 245.875 & & 2.68 \\
\hline CP1-92 & 9.6 & Bear Lake & 0.041 & 0.076 & & 2.69 & SR2-89.5 & 35.3 & Milky River & 3425.436 & 3553.977 & & 2.70 \\
\hline LH1-66.5 & 6.5 & Bear Lake & 0.055 & 0.098 & & 2.67 & 04RR154B & 42.0 & Milky River & ns & ns & & 2.81 \\
\hline 04RR148B & 9.8 & Bear Lake & 0.063 & 0.110 & & 2.68 & 04RR158C & 35.0 & Milky River & ns & ns & 125.000 & 2.73 \\
\hline SD1-86 & 4.9 & Bear Lake & 0.184 & 0.280 & & 2.68 & 04RR158G & 35.6 & Milky River & ns & ns & 76.600 & 2.63 \\
\hline CP1-11 & 13.6 & Bear Lake & 0.190 & 0.288 & & 2.66 & 04RR6B & 2.7 & Naknek & 0.002 & 0.008 & & 2.51 \\
\hline SD1-10 & 10.8 & Bear Lake & 0.191 & 0.310 & & 2.66 & 04RR23A & 1.5 & Naknek & 0.005 & 0.014 & & 2.68 \\
\hline 04RR152C & 11.9 & Bear Lake & 0.242 & 0.377 & & 2.72 & 04TJR09 & 5.3 & Naknek & 0.026 & 0.051 & & 2.52 \\
\hline LH1-2 & 8.9 & Bear Lake & 0.474 & 0.691 & & 2.68 & 04RR2C & 3.8 & Naknek & 0.074 & 0.126 & & 2.63 \\
\hline СP1-26 & 11.2 & Bear Lake & 0.582 & 0.870 & & 2.64 & O4RR12B & 5.0 & Naknek & 0.114 & 0.184 & & 2.61 \\
\hline 04RR8B & 36.1 & Bear Lake & ns & ns & 41.4 & 2.63 & O4RR2D & 4.6 & Naknek & 0.137 & 0.216 & & 2.60 \\
\hline 04RR8D & 39.6 & Bear Lake & ns & ns & 0.251 & 2.49 & O4RR7D & 4.5 & Naknek & 1.562 & 2.195 & & 2.56 \\
\hline 04RR8E & 38.4 & Bear Lake & ns & ns & 0.066 & 2.46 & 04RR19B & 6.3 & Naknek & 2.433 & 3.382 & & 2.62 \\
\hline 04RR153D & 9.2 & Bear Lake & ns & ns & 0.180 & 2.71 & O4RR26B & 4.6 & Naknek & 3.829 & 5.366 & & 2.61 \\
\hline LH1-98 & 16.9 & Bear Lake & ns & ns & 0.065 & 2.69 & O4RR20B & 13.9 & Naknek & ns & ns & 0.223 & 2.74 \\
\hline LH1-182 & 11.3 & Bear Lake & ns & ns & 0.037 & 2.62 & O4RR22B & 6.5 & Naknek & ns & ns & 48.1 & 2.56 \\
\hline SD1-41 & 10.0 & Bear Lake & ns & ns & 0.08 & 2.68 & O4RR6D & 7.2 & Naknek & ns & ns & 20.0 & 2.71 \\
\hline 04RR163C & 14.1 & Bear Lake & ns & ns & 0.448 & 2.73 & 04RR7B & 7.2 & Naknek & ns & ns & 37.7 & 2.57 \\
\hline CP1-178 & 11.2 & Bear Lake & ns & ns & 0.870 & 2.66 & 04RR157B & 8.1 & Naknek & 44.113 & 52.914 & & 2.59 \\
\hline 04RR150B & 2.6 & Chignik & 0.001 & 0.004 & & 2.71 & 04RR30B & 3.5 & Shelikof & 0.002 & 0.006 & & 2.70 \\
\hline 04RR141B & 13.8 & Chignik & 0.008 & 0.020 & & 2.69 & 04RR18B & 3.6 & Shelikof & 0.004 & 0.010 & & 2.62 \\
\hline 04RR149B & 4.6 & Chignik & 0.308 & 0.447 & & 2.71 & 04RR1D & 6.7 & Shelikof & 0.005 & 0.014 & & 2.63 \\
\hline 04RR151C & 7.1 & Chignik & 1.230 & 1.694 & & 2.66 & 04RR16B & 3.7 & Shelikof & 0.006 & 0.016 & & 2.73 \\
\hline 04RR142B & 12.4 & Chignik & ns & ns & 1.950 & 2.68 & 04RR15G & 5.3 & Shelikof & 0.008 & 0.019 & & 2.73 \\
\hline 04RR156B & 4.6 & Herendeen & 0.001 & 0.004 & & 2.70 & 04RR29A & 5.2 & Shelikof & 0.008 & 0.020 & & 2.65 \\
\hline 04RR156D & 1.1 & Herendeen & 0.002 & 0.006 & & 2.68 & O4RR28B & 7.7 & Shelikof & 0.043 & 0.079 & & 2.80 \\
\hline HS1-16 & 7.3 & Herendeen & 0.002 & 0.007 & & 2.67 & 04RR15B & 8.5 & Shelikof & 0.110 & 0.178 & & 2.73 \\
\hline HS1-8.5 & 5.1 & Herendeen & 0.007 & 0.018 & & 2.60 & O4RR15D & 6.4 & Shelikof & 0.165 & 0.254 & & 2.71 \\
\hline HS1-2.5 & 7.9 & Herendeen & 0.007 & 0.018 & & 2.70 & 04RR13B & 4.9 & Shelikof & 0.374 & 0.522 & & 2.69 \\
\hline HS1-12 & 5.3 & Herendeen & 0.009 & 0.022 & & 2.68 & O4RR18D & 8.4 & Shelikof & 0.446 & 0.689 & & 2.73 \\
\hline HS1-5.5 & 6.3 & Herendeen & 0.049 & 0.088 & & 2.73 & O4RR30D & 10.1 & Shelikof & ns & ns & 0.462 & 2.70 \\
\hline 041RR139D & 11.0 & Herendeen & 0.793 & 1.188 & & 2.68 & 04RR138 & 16.6 & Stepovak & 0.004 & 0.012 & & 2.70 \\
\hline 04RR139C & 11.6 & Herendeen & ns & ns & 1.080 & 2.64 & 04RR155B & 7.0 & Tolstoi & 0.002 & 0.005 & & 2.71 \\
\hline \multirow[t]{2}{*}{ O4RR9B } & 9.7 & Kialagvik & 0.001 & 0.005 & & 2.77 & 04RR168B & 4.4 & Tolstoi & 0.004 & 0.010 & & 2.75 \\
\hline & & & & & & & 04RR155B & 9.6 & Tolstoi & 0.099 & 0.163 & & 2.72 \\
\hline
\end{tabular}

Table 2.1. Porosity and permeability (81 conventional core analyses) of outcrop samples performed by Core Laboratories, Inc, at 400 psig net confining stress ( $n s=$ not suitable for analysis). 


\section{Porosity and Permeability by Formation}

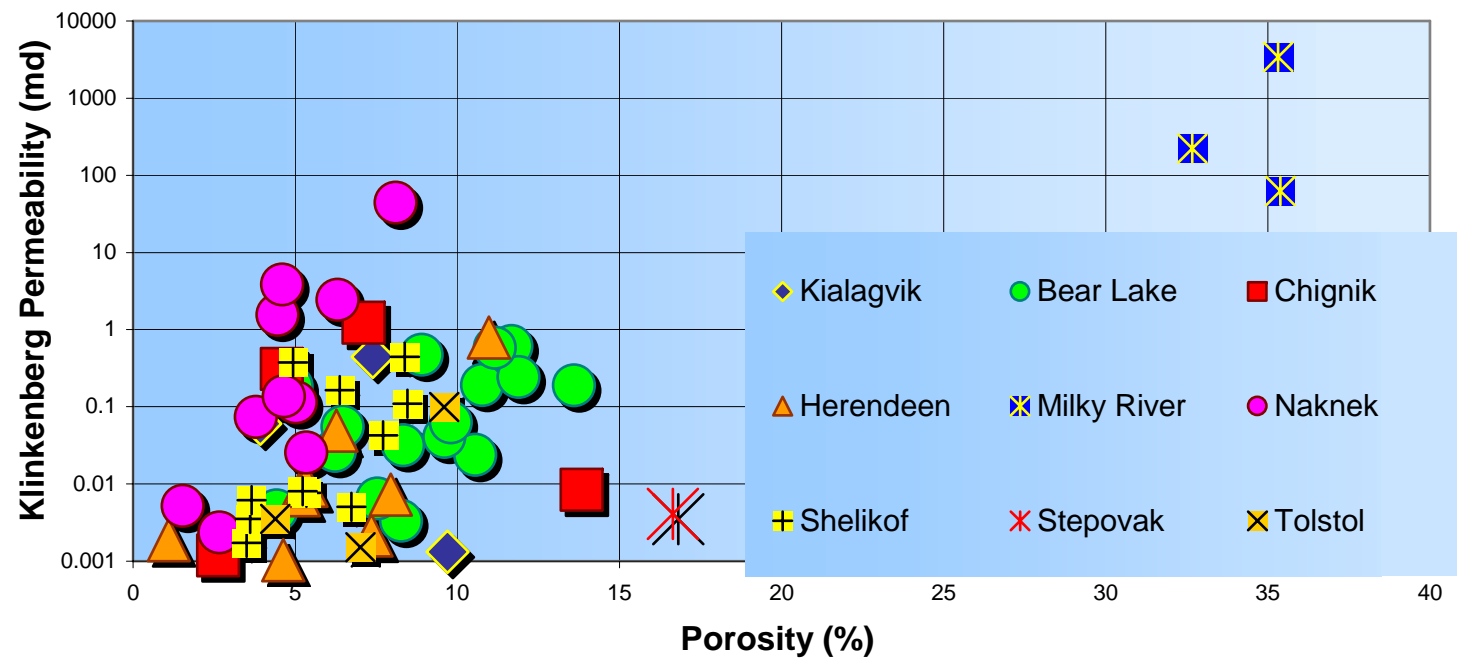

Figure 2.1. Porosity and permeability of outcrop samples (by formation); md - millidarcies 


\begin{tabular}{|c|c|c|c|c|c|c|c|c|c|c|}
\hline SAMPLE & FORMATION & $\begin{array}{c}\text { Temperature } \\
\text { Max }\end{array}$ & $\begin{array}{c}\text { Total Organic } \\
\text { Carbon } \\
\text { (TOC) }\end{array}$ & S1 & $\mathrm{S} 2$ & S3 & $\mathrm{Pl}$ & S2/S3 & $\mathrm{HI}$ & $\mathrm{Ol}$ \\
\hline NAS - 8056 & Stepovak Formation & 433 & 1.12 & 0.134 & 0.8 & 0.95 & 0.143 & 0.84 & 71.42857 & 84.82143 \\
\hline NAS - 9264 & Stepovak Formation & 429 & 1.79 & 0.1668 & 1.7 & 1.15 & 0.089 & 1.48 & 94.97207 & 64.24581 \\
\hline NAS - 10739 & Tolstoi Formation & 426 & 6.21 & 0.5631 & 15.19 & 1.64 & 0.036 & 9.26 & 244.6055 & 26.40902 \\
\hline NAS - 12262 & Tolstoi Formation & 431 & 8.74 & 0.8893 & 18.81 & 1.27 & 0.045 & 14.8 & 215.2174 & 14.53089 \\
\hline NAS - 12269 & Tolstoi Formation & 420 & 26.74 & 2.6594 & 60.64 & 3.5 & 0.042 & 17.3 & 226.7764 & 13.08901 \\
\hline NAS - 12635 & Tolstoi Formation & 430 & 5.14 & 0.6087 & 9.05 & 1 & 0.063 & 9.05 & 176.07 & 19.45525 \\
\hline NAS - 12636 & Tolstoi Formation & 425 & 5.73 & 0.5673 & 14.72 & 1.12 & 0.037 & 13.1 & 256.8936 & 19.54625 \\
\hline NAS - 14167 & Tolstoi Formation & 426 & 16.535 & 7.4606 & 56.6 & 2.22 & 0.116 & 25.5 & 342.3042 & 13.42607 \\
\hline NAS - 14184 & Tolstoi Formation & 448 & 40.4 & 10.137 & 84.8 & 3.52 & 0.107 & 24.1 & 209.901 & 8.712872 \\
\hline NAS - 16006 & Tolstoi Formation & 448 & 1.43 & 0.4507 & 1.31 & 0.54 & 0.256 & 2.43 & 91.60839 & 37.76224 \\
\hline NAS - 16012 & Tolstoi Formation & 452 & 2.51 & 0.6014 & 4.22 & 0.83 & 0.125 & 5.08 & 168.1275 & 33.06773 \\
\hline NAS - 16021 & Tolstoi Formation & 462 & 1.59 & 0.4571 & 3.12 & 0.79 & 0.128 & 3.95 & 196.2264 & 49.68554 \\
\hline NAS - 16025 & Tolstoi Formation & 449 & 2.32 & 0.6781 & 4.83 & 0.95 & 0.123 & 5.08 & 208.1897 & 40.94828 \\
\hline NAS - 16026 & Tolstoi Formation & 449 & 1.98 & 0.4734 & 2.57 & 0.53 & 0.156 & 4.85 & 129.798 & 26.76768 \\
\hline NAS - 16708 & Tolstoi Formation & 458 & 1.17 & 0.274 & 0.87 & 0.36 & 0.239 & 2.42 & 74.35898 & 30.76923 \\
\hline NAS - 16718 & Tolstoi Formation & 452 & 2.28 & 0.74 & 2.63 & 0.93 & 0.22 & 2.83 & 115.3509 & 40.78947 \\
\hline
\end{tabular}

Main expelled

product at peak

\begin{tabular}{|c|c|c|c|}
\hline Kerogen Type & HI & S2/S3 & $\begin{array}{c}\text { Product at peak } \\
\text { maturity }\end{array}$ \\
\hline I & $>600$ & $>15$ & Oil \\
\hline II & $300-600$ & $10-15$ & Oil \\
\hline IIIIII & $200-300$ & $5-10$ & Mixed oil and gas \\
\hline III & $50-200$ & $1-5$ & Gas \\
\hline IV & $<50$ & $<1$ & None \\
\hline
\end{tabular}

PI

$<0.10$ Immature

0.10-0.15 Early mature

0.25-0.40 Peak mature

$>0.40 \quad$ Late mature

Table 2.2. Organic geochemistry and hydrocarbon generating parameters for 16 samples from the North Aleutian Shelf COST well. Sample numbers designate depth in COST well from Kelly Bushing. 


\section{Vitrinite Reflectance (Ro)}

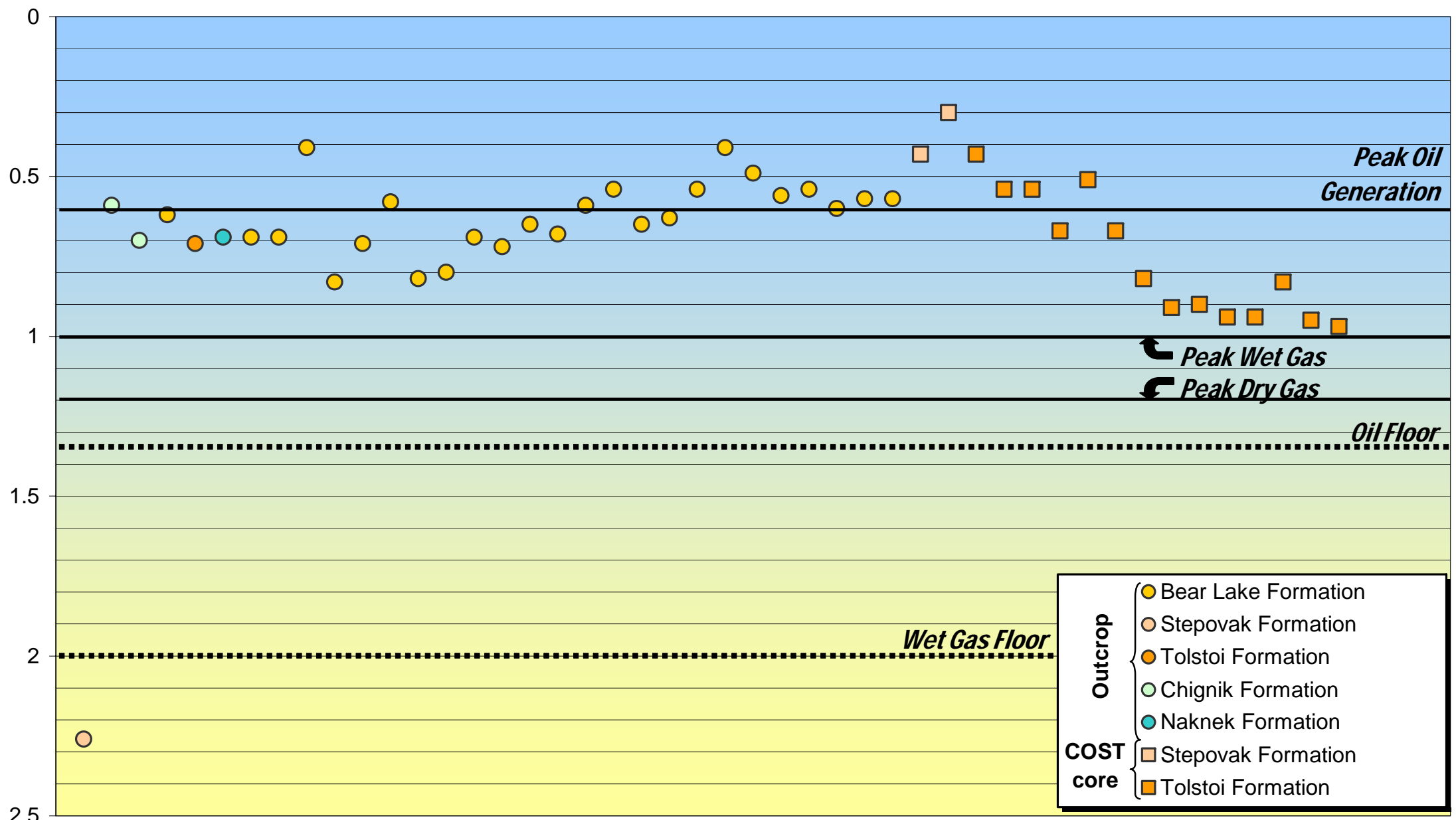

Figure 2.2. Vitrinite reflectance (Ro) analyses of 30 outcrop samples from the Tertiary and Mesozoic stratigraphy, Port Moller and Wide Bay areas, Alaska Peninsula, and 16 Tertiary samples from the NAS COST well. The Ro value of 0.6 is used as the boundary between "immature" and "mature" hydrocarbon source potential. See figure six for kerogen typing analyses of 16 NAS COST well samples. 


\section{Becharof State \#1}

$\diamond$ Stepovak Formation $\quad$ Bear Lake Formation

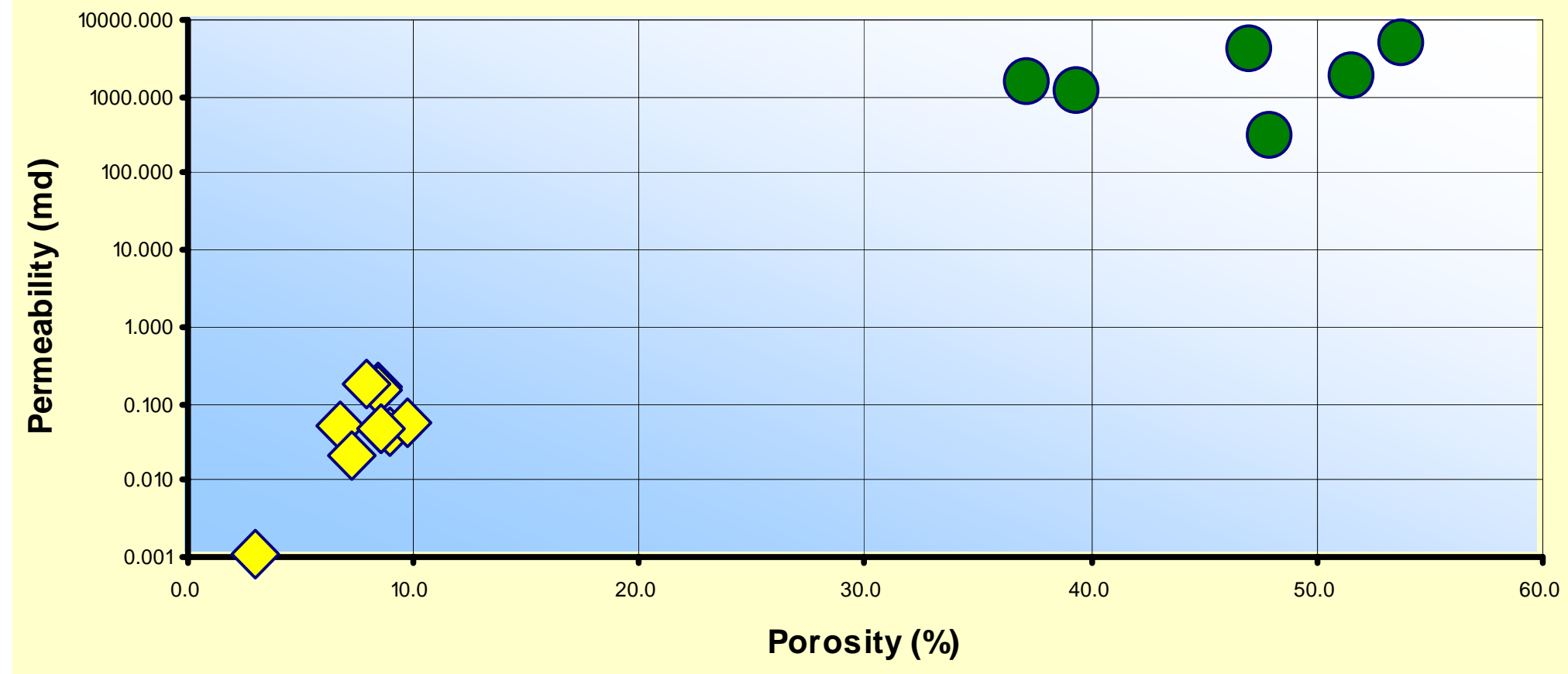

Figure 2.3. Porosity and permeability plot of 14 samples from the Becharof State \#1 well. 


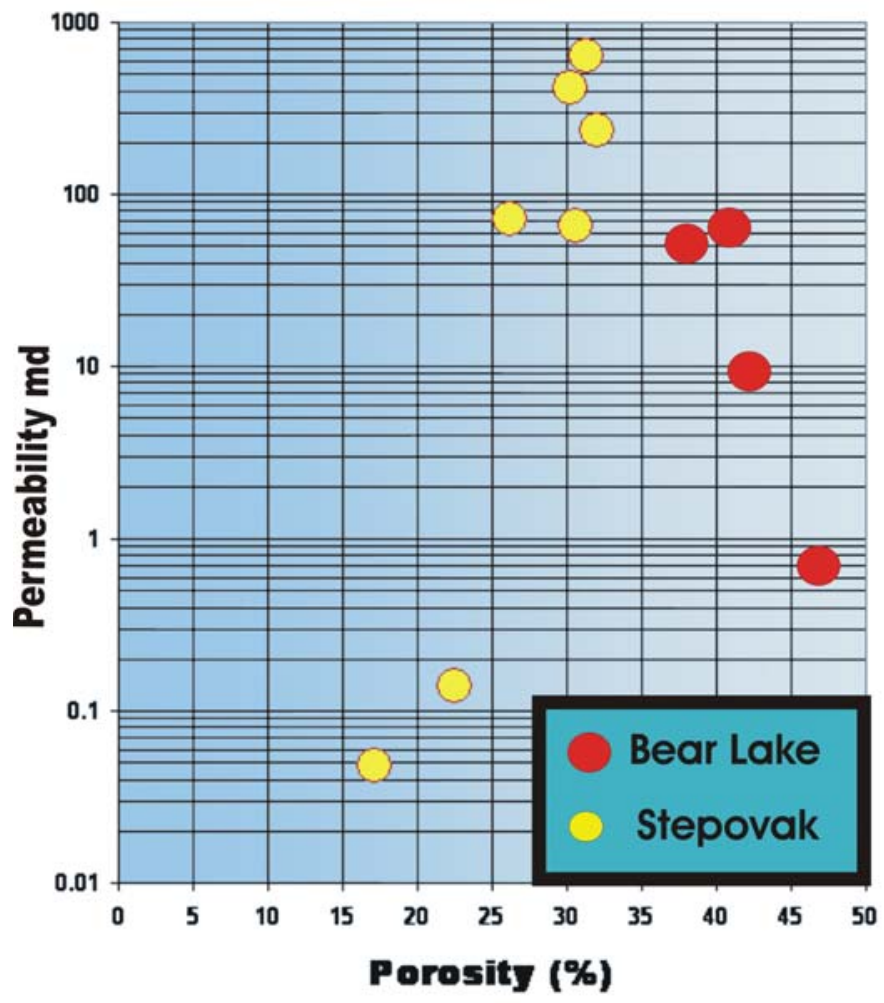

Figure 2.4. North Aleutian Shelf COST well (NAS COST) porosity and permeability analyses. These 11 drill core samples range in depth from 3,393 to 9,957 feet. The Bear Lake Formation samples range in depth from 3,393 to 4,198 feet, and the Stepovak Formation samples range in depth from 5,234 to 9,957 feet. 


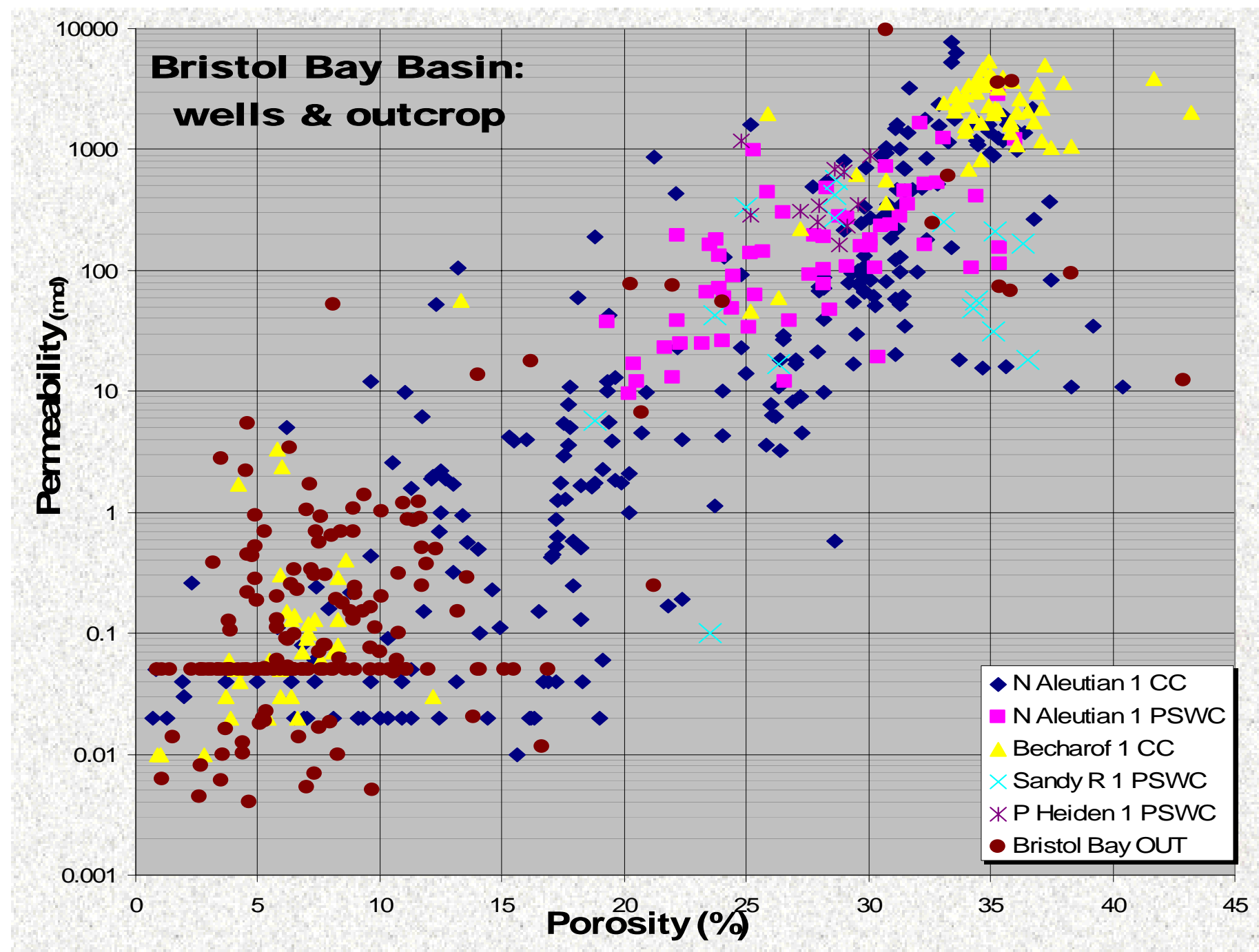

Figure 2.5. Porosity and permeability data from four Alaska Peninsula wells, and outcrop samples (collected during the 2004 field program). The North Aleutian Shelf COST well data is from Turner and others (1988). The other well data are from the Alaska Division of Oil \& Gas public archives. The "Bristol Bay OUT" data is the outcrop data and the same as in figure 
Oxygen Index vs Hydrogen Index - NAS-COST core

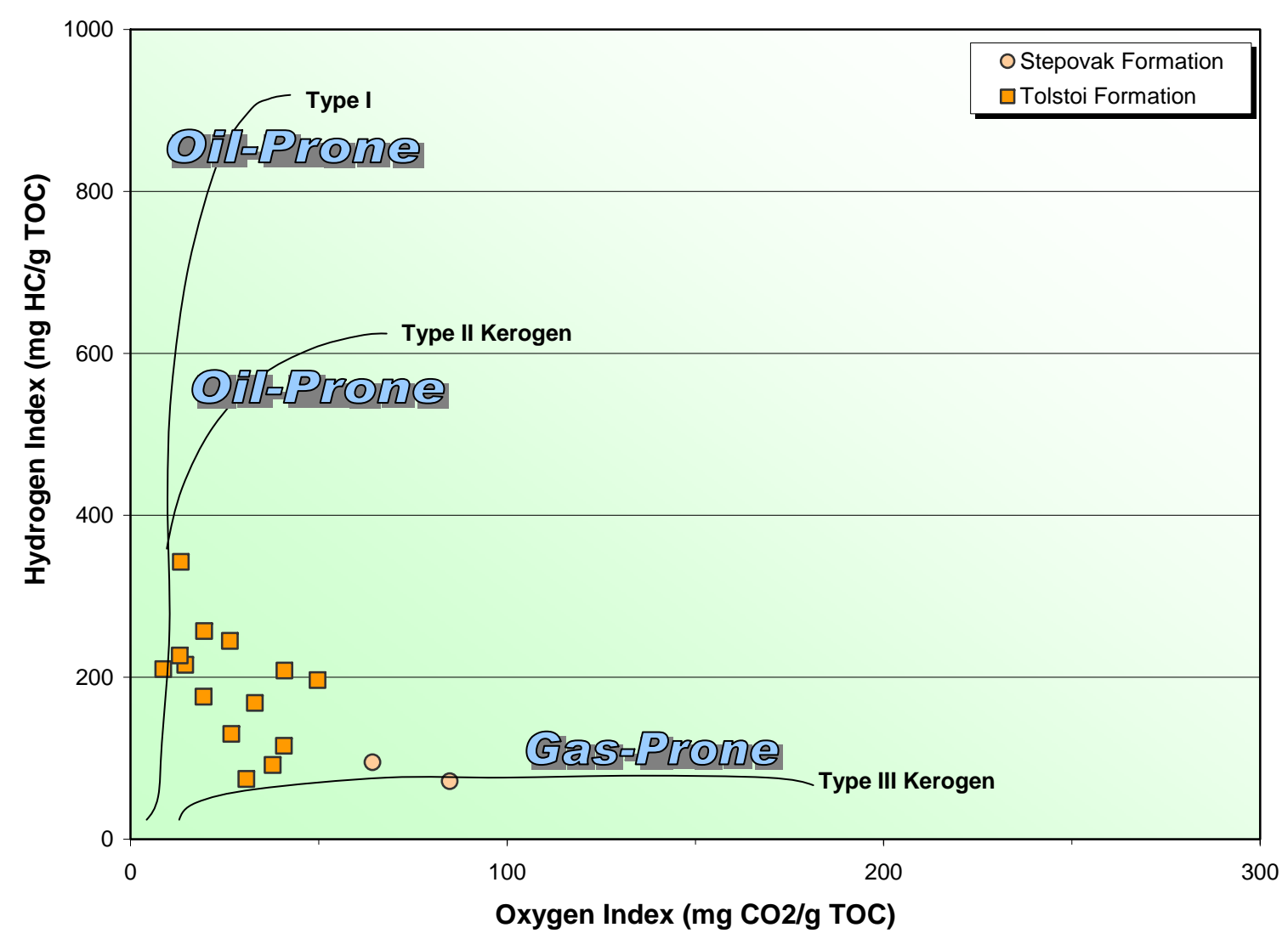

Figure 2.6. Kerogen typing diagram of organic geochemistry analyses from 16 NAS COST well core samples. The oxygen index versus hydrogen index values define kerogen type, and as a consequence whether that kerogen type is prone to generate oil or gas. These drill core samples range in depth from 8,056 to 9,264 feet for the Eocene and Oligocene Stepovak Formation, and 10,729 to 16,718 feet for the Paleocene and Eocene Tolstoi Formation. The two Stepovak Formation samples are the most oxygen index-rich and show the strongest type two kerogen affinity of the 16 drill core samples. 


\section{Section III. Sedimentology, Stratigraphy \& Reservoir Characterization}

The objective of this part of the report is to discuss the stratigraphic framework and reservoir properties of the Bear Lake and Milky River formations exposed in the Port Moller area of the Alaska Peninsula. These two formations are potential reservoirs for hydrocarbons in the Bristol Bay basin. The key data for this analysis are stratigraphic sections measured by Ken Ridgway (Purdue University) and Emily Finzel (Alaska Division of Geological \& Geophysical Surveys). These sections were measured from August 23 to September 2, 2004. The three main goals of the study were to (1) determine the depositional setting of each formation; (2) delineate the stratigraphy of the Bear Lake Formation through palynological and stratigraphic correlations; and (3) evaluate the reservoir properties of each formation. James White (Geological Survey of Canada) completed the palynological analyses, and will release a report with the detailed results (White, 2005). Richard Evoy (PetroCanada) helped with identification of trace fossils.

\section{Bear Lake Formation}

The Miocene Bear Lake Formation is well exposed along the north coast of the Alaska Peninsula near the community of Port Moller and in the mountains to the south (fig. 1.1). The Bear Lake Formation may be as thick as $1,000 \mathrm{~m}$ in outcrop, and is 2,368 $\mathrm{m}$ in the Gulf Oil Corporation Sandy River Federal No. 1 well (fig. 3.1; Brockway and others, 1975; Detterman and others, 1996). This formation is considered to have the highest potential for hydrocarbon production in the Bristol Bay basin (Lyle and others, 1979). Previous studies of the macrofauna of the Bear Lake Formation have assigned it a Middle to Late Miocene age (Marincovich, 1983, 1988; Marincovich and McCoy, 1984). Previous studies of the stratigraphy and sedimentology of the Bear Lake Formation are limited but in general suggest deposition in neritic to tidal flat environments (Wisehart, 1971; Nilsen, 1984). We have measured four stratigraphic sections in the Bear Lake Formation that we interpret as representing proximal to distal deposits of a regional estuarine/tidal flat system (fig. 3.1).

\section{Coal Point 1 Measured Section}

Location:

This measured section is located along the west coast of Herendeen Bay and labeled CP1 on figure 3.1. The GPS location for the base of the section is $55.78596^{\circ} / 160.87172^{\circ}$ and it is located in the Port Moller D-3 Quadrangle. Bedding has a strike and dip of $190^{\circ} / 26^{\circ}$ SW at this location.

\section{Lithofacies Description:}

The section consists of two main lithofacies associations that are separated by a fault at $\sim 40 \mathrm{~m}$ on the measured section (fig. 3.3). The lowermost $40 \mathrm{~m}$ of the section consists of highly bioturbated sandstone (fig. 3.4A). Sandstone in this part of the section also contains well developed lateral accretionary surfaces (25 m on fig. 3.3), and mud drapes are common on all stratification types. Trace fossils documented in this part of the section include Rosselai, Teredolites (fig. 3.4B), and possibly crab burrows. The ichnofacies appear to be characterized by high abundance and low diversity.

The middle and upper parts of the section (40-187 m on fig. 3.3) are characterized by trough cross-stratified sandstone interbedded with coal and organic-rich mudstone (fig. 3.4C). Sandstone channels between 40 and $75 \mathrm{~m}$ on the measured section are $3 \mathrm{~m}$ in length and $1 \mathrm{~m}$ thick. Internally they contain ripple stratification with mud drapes on ripple foresets, and are interbedded with ripple-laminated siltstone. Upsection the sandstone channels become thicker and are dominated by trough cross stratification (fig. 3.3). Cross set thicknesses are up to $70 \mathrm{~cm}$ and individual foresets are draped by organic material (fig. 3.4D). There is a distinct lack of bioturbation and macrofauna throughout the middle and upper parts of the section. Organic-rich beds include coal seams up to $70 \mathrm{~cm}$ thick (132 m on fig. 3.3), but smaller seams are common throughout this part of the section. Interbedded finergrained siliciclastic facies in the upper section contain fossilized upright tree trunks that are up to $50 \mathrm{~cm}$ long and well preserved leaf fossils (fig. 3.4E, F).

\section{Depositional Interpretation:}

We interpret the lower $40 \mathrm{~m}$ of the Coal Point 1 section as representing intertidal brackish/marine channels and mud/sand flats based on the amount and types of bioturbation, and the documentation of lateral accretionary surfaces and mud-draped foresets in the sandstone. These facies are much better exposed in the Sundean 1 measured section so they will not be discussed in detail in this part of the report.

The middle and upper parts of the Coal Point 1 section are interpreted as nonmarine fluvial and swamp deposits. The dominance of non-bioturbated, trough cross stratified sandstone with organic drapes on individual 
foresets, and the thick coal seams, are all indicative of terrestrial environments. Our working hypothesis is that the Coal Point 1 measured section represents the most proximal facies of a regional estuarine/tidal flat depositional system (fig. 3.2).

Age:

Analysis of six fine-grained samples spanning the entire thickness of the Coal Point 1 measured section suggest that it may represent the oldest part of the Bear Lake Formation studied to date. The age interpretation of this section is compromised by poor preservation of palynomorphs. Undeterminable palynomorphs account for up to 50 percent of the pollen assemblage. The rest of the pollen assemblage is dominated by Taxodiaceae-CupressaceaeTaxa undifferentiated (T-C-T) with little representation of Pinaceae or angiosperms. In spite of the poor preservation, it is clear that the Coal Point 1 measured section is dominated by $\mathrm{T}-\mathrm{C}-\mathrm{T}$ pollen. This suggests that the assemblage represents an interval of warm climate, and hence likely predates the distinct temperature decline that began around $15 \mathrm{Ma}$ (for example, Zachos and others, 2001; White and others, 1997, 1999). This line of reasoning would suggest that the Coal Point measured section is upper lower Miocene to earliest middle Miocene in age.

\section{Reservoir Properties:}

Analysis of six sandstone samples from the Coal Point 1 measured section yielded porosities ranging from 613 percent, and permeabilities ranging from 0.008 to $0.582 \mathrm{md}$. Vitrinite reflectance values from five coal samples ranged from 0.54 to 0.60 .

\section{Bear Lake 1 Measured Section}

\section{Location:}

This measured section is located in the headwaters of the Milky River and labeled BL1 on figure 3.1. The GPS location for the base of the section is $55.99159^{\circ} / 160.00693^{\circ}$ and it is located in the Port Moller D-1 Quadrangle. Bedding has a strike and dip of $325^{\circ} / 55^{\circ} \mathrm{NW}$ at this location.

\section{Lithofacies Description:}

The measured section shown on figure 3.5 represents only the well exposed middle part of the Bear Lake Formation in this area (fig. 3.6A). The lower part of the Bear Lake Formation is not well exposed and the upper part is fairly inaccessible. This discussion includes observations from the entire Bear Lake Formation even though we only measured the better exposed middle part. The interval that was measured is fairly representative of the entire Bear Lake Formation in this area based on our observations. The lower part of the measured section shown on figure 3.5 is dominated by ripple-laminated sandstone, trough and planar cross-stratified sandstone (fig. 3.6B), and $\mathrm{coal} / \mathrm{siltstone}$. Coal seams are up to $1.8 \mathrm{~m}$ thick in this part of the section (at $1 \mathrm{~m}$ on fig. 3.5). The middle part of this measured section is characterized by wavy-bedded (fig. 3.6C) and flaser bedded sandstone/siltstone (fig. 3.6D). The wavy and flaser bedded sandstone described for this part of the measured section is common throughout the entire Bear Lake Formation in this area. Maximum coal seam thickness in this middle part of section reaches $2.7 \mathrm{~m}$ (at 92 $\mathrm{m}$ on fig. 3.5). The upper part of the measured section is not well exposed, but contains massive and wavy-bedded sandstone with minor interbeds of conglomerate.

\section{Depositional Interpretation:}

We interpret the majority of the lithofacies in the Bear Lake 1 measured section to represent deposition in fluvial and freshwater tidal marshes of a regional estuarine/tidal flat system (fig. 3.2). The dominance of nonbioturbated wavy and flaser bedded sandstone, along with thick coal seams, all suggest that deposition occurred in the freshwater-dominated part of the estuarine/tidal flat system. Wavy and flaser bedding are common in tidal depositional systems due to periodic changes in current flow velocity (Dalrymple, 1992). These types of sedimentary structures develop when a bed of ripples is formed by the maximum current of the dominant tide, followed by deposition of a mud layer during the ensuing slack-water period. The lack of burrowing is also important for our interpretation because it implies a water chemistry not favored by typical marine organisms. In the proximal (landward) parts of estuarine/tidal flat systems, freshwater input produces brackish water chemistries that restrict the occurrence of many burrowing organisms in this part of the depositional system.

Age:

Analysis of six fine-grained samples from the Bear Lake Formation in this area yielded good recovery of palynomorphs. Taxodiaceae-Cupressaceae-Taxa undifferentiated (T-C-T) pollen is less than 25 percent of the total assemblage and declines to 10 percent upsection. Pinaceae is common and characterized by the consistent presence 
of Tsuga spp., especially T. canadensis and heterophylla types. The angiosperms are most commonly represented by Alnus, Betula, Ericales, Triporopollenties. The middle part of the section yielded angiosperms that have adaptations to warm climates, namely Acer, Carya, Fagus, Ilex-type and Pterocarya.

These taxa occurrences suggest that they are in the early to middle Homerian stage of Wolfe (1994). Thus, the probable age of the Bear Lake 1 measured section is about 10-11 Ma (Late Miocene).

\section{Reservoir Properties:}

We did not analyze any of the sandstones from the Bear Lake 1 measured section due to their poorly consolidated texture. Vitrinite reflectance analysis from 13 of the coal samples yielded values of 0.41 to 0.83 .

\section{Sundean 1 Measured Section}

Location:

This measured section is located along the peninsula between the Right Head and Left Head at the head of Port Moller Bay (fig. 3.1). The GPS location for the base of the section is $55.81693^{\circ} / 160.31337^{\circ}$ and it is located in the Port Moller D-1 Quadrangle. Bedding has a strike and dip of $70^{\circ} / 13^{\circ} \mathrm{NW}$.

\section{Lithofacies Description:}

This measured section is dominated by coarse sandstone that is predominantly bioturbated and commonly contains extremely well developed lateral accretionary surfaces (figs. 3.7, 3.8A, B). The sandstone beds are in channels that are on the order of tens of meters wide and are laterally equivalent to thick sections of flaser- and wavy-bedded siltstone and fine-grained sandstone. Distinct horizons of pebbles and isolated outsized clasts are also common in the sandstones. Clast types in pebble horizons are usually volcanic, quartz, and quartzite. Locally, some of the sandstones contain planar cross stratification that indicates general northwestward sediment transport. Bioturbation is extensive in the sandstone and is qualitatively characterized as high abundance and high diversity. Well preserved Arenicolites trace fossils are common. Articulated oyster fossils are concentrated in beds that are up to $2 \mathrm{~m}$ in thickness ( $47 \mathrm{~m}$ on fig. 3.7). Fine-grained beds in this section are most commonly ripple-laminated siltstone.

\section{Depositional Interpretation:}

We interpret the Sundean 1 measured section to have been deposited in intertidal channels and mud-rich tidal flats in brackish and marine parts of a regional estuarine/tidal flat system (fig. 3.2). The well developed lateral accretionary surfaces are the product of migrating point bars in tidal channels that were laterally equivalent to mudrich tidal flats. Mud-rich tidal flats characterize the upper parts of modern estuarine/tidal flat systems (Dalrymple, 1992). Migrating tidal channels crosscut the mud-rich tidal flats; flow velocities of both the flood and ebb tidal currents are highest in these channels. The local occurrence of planar cross stratification in the Sundean 1 measured section indicates that flow velocities were high enough to have produced migrating sand waves in the deeper part of the tidal channels. Oysters are interpreted to have lined the banks of active and abandoned tidal channels in the estuarine system that deposited this part of the Bear Lake Formation. In modern estuarine systems, oysters commonly occupy the sandy substrate of tidal channels for colonizing relative to mud-rich substrates in the laterally equivalent tidal flats (Richard Evoy, oral communication, 2004). The thin horizons of pebbles within the sandstone and siltstone represent deposition by storms when coarse detritus was spread across the entire estuarine/tidal system.

Age:

Analysis of three fine-grained samples from the Sundean 1 measured section recovered woody organic detritus, but were virtually barren of palynomorphs. Due to the lack of recovery, no age determination is possible.

\section{Reservoir Properties:}

Measurements of five sandstone samples from the Sundean 1 measured section yielded porosities ranging from 4 to 10 percent and permeabilities from 0.003 to $0.191 \mathrm{md}$.

\section{Left Head 1 Measured Section}

Location:

This measured section is located along the east coast of Port Moller Bay southeast of Egg Island and is labeled LH1 on figure 3.1. The GPS location for the base of the section is $55.87441^{\circ} / 160.34538^{\circ}$ and it is located in the Port Moller D-2 Quadrangle. 


\section{Lithofacies Description:}

This measured section consists of three main facies associations. The lower $70 \mathrm{~m}$ of the section consists of bioturbated, coarse sandstone in broad, low-relief channels that are $1-2 \mathrm{~m}$ in height and $\sim 5 \mathrm{~m}$ wide (figs. 3.9, 3.10A). These packages of sandstone channels are laterally extensive at the scale of the outcrop and have tabular geometries (fig. 3.10A). Internally, these channels contain low-angle swaley stratification that follows the contours of the channel. Most of the stratification is defined by mud drapes along individual foresets (fig. 3.10A). Bioturbation of mud-draped stratification results in wispy, discontinuous mud lenses with the sandstone beds. Pebble lags are also common in this facies and locally contain clasts 5-8 cm in diameter. Common clast types are volcanic, quartz, and chert. Coalified wood fragments are also common in this facies. Flaser bedded siltstone and fine sandstone are interbedded with the coarse, bioturbated sandstone.

The middle part of the measured section ( $70-175 \mathrm{~m}$ on fig. 9) is characterized by bioturbated sandstone interbedded with thin conglomerate beds that commonly contain disarticulated oyster shells (fig. 3.10C). This facies association contains extensive trace fossils that qualitatively appear to have high abundance and high diversity. Skolithos and Thalassinoides trace fossils are quite common. Distinct horizons of outsized clasts occur in this part of the section with some clasts having diameters up to $35 \mathrm{~cm}$ (fig. 3.10D).

The uppermost part of the measured section ( 175-205 m on fig. 3.9) contains well developed trough cross stratification with thin pebble lags. Disarticulated oyster shell fragments are common. Locally, bioturbation is well developed.

\section{Depositional Interpretation:}

Overall, we interpret the Left Head 1 section to represent deposition in sand-dominated subtidal channels and flats in the fully marine distal parts of a regional estuarine/tidal flat system (fig. 3.2). Sand flats commonly form the lower, more distal parts of modern estuarine/tidal flat systems (Dalrymple, 1992). The dominance of swaley and planar cross stratification in the Left Head 1 section indicates that sandy macrofaunas migrated through the interpreted subtidal channels. Locally, parts of the section were deposited in lower intertidal environments as evidenced by the lateral accretionary surfaces and flaser bedding. The distinct horizons of conglomerate clasts within the bioturbated sandstone represent storm deposits that spread coarse detritus across the entire estuarine/tidal flat depositional system. The abundance of disarticulated oyster fossils suggests that the oysters were transported from their living communities located in intertidal channels out into deeper subtidal environments represented by the Left Head 1 section. The common occurrence of mud drapes on the swaley stratification indicates that there were still abrupt decreases in flow velocity in this part of the estuarine depositional system.

Age:

Analysis of five fine-grained samples from the Left Head 1 measured section suggest that it may represent the youngest part of the Bear Lake Formation studied to date. The Pinaceae dominate the palynomorph assemblage; Tsuga spp. are consistently and commonly represented. Angiosperm pollen is common, especially Alnus, Betula, Ericales, and Triporopollenites. Thermophilous (warm-loving) angiosperm palynomorphs are common in samples from the lower part of the section between 27.5 and $76 \mathrm{~m}$. These samples commonly include Acer, Carya, Pterocarya and Ulmus-tupe. These thermophilous taxa occurrences suggest a Late Miocene age for the Left Head 1 section, around 10-11 Ma.

If one considers the occurrences of thermophilous angiosperm palynomorphs between the Left Head 1 and Bear Lake 1 sections, the samples in the upper Bear Lake 1 section may correlate with those in the lower Left Head 1 section. If this correlation is correct, the uppermost Left Head 1 measured section is the youngest of the three measured sections with palynological results.

\section{Reservoir Properties:}

Analysis of six sandstone samples from the Left Head 1 measured section yield porosities ranging from 4 to 17 percent and permeabilities from 0.005 to $0.474 \mathrm{md}$.

\section{Milky River Formation}

The Milky River Formation is best exposed in the higher topography between Bear Lake and Sandy Lake in the Port Moller area (fig. 3.1). The "Milky River Formation” was defined by Galloway (1974) as the volcanic and sedimentary strata overlying the Bear Lake Formation along the Milky River. At its type locality, the Milky River Formation is about $465 \mathrm{~m}$ thick, whereas in the onshore Gulf Oil Corporation Sandy River Federal \#1 well, the Milky River Formation is about 1,012 m thick (Brockway and others, 1975; Detterman and others, 1996). Detterman 
and others (1996) interpreted the entire Milky River Formation as being deposited in nonmarine environments. Lyle and others (1979), however, documented marine fossils that they interpreted as shallow marine fauna in the Milky River Formation. We have measured one stratigraphic section in the lowermost part of the Milky River Formation that we interpret a shallow marine shelf deposit.

\section{Sandy Ridge Measured Section}

Location:

This measured section is located along the southwest side of the ridge south of Sandy Lake and is labeled SR1 on figure 3.1. The GPS location for the base of the section is $56.05875^{\circ} / 159.91690^{\circ}$ and it is located in the Chignik A-6 Quadrangle. Bedding is horizontal at this location.

\section{Lithofacies Descriptions:}

This section is characterized by thick-bedded, highly bioturbated and fossiliferous, coarse-grained sandstone (figs. 3.11, 3.12A). The sandstone is extremely rich in mollusk fossils, many of which appear to be in life position (figs. 3.12B-D). A few gastropod fossils were also documented. Trace fossils are quite common in this section with Skolithos and Rhizocarallium being particularly common. Almost all sedimentary structures in the thicker-bedded sandstones appear to have been obliterated by the extensive bioturbation. Isolated outsized clasts are common in the sandstones (fig. 3.12E).

Locally, sandstones are rich in volcanic fragments. These include pumice-rich sandstone that is horizontally stratified (2-4 m on fig. 3.11; fig. 3.12F), and a distinctive sandstone rich in red and black basalt/tuff fragments that commonly contains trough cross stratification (fig. 3.12G).

\section{Depositional Interpretation:}

The molluscan-rich fossil assemblage in highly bioturbated sandstones, as well as the horizontal stratification and trough cross stratification found locally in these sandstones, are interpreted to represent deposition in shallow open-marine conditions. The stratification types are indicative of tractive transport of sediment and development of bedforms. Horizontal stratification and trough cross stratification form in upper flow regime conditions and are common sedimentary structures in nearshore marine environments (Harm and others, 1982). Some of the identified mollusk fossils are similar to modern species that prefer sand/gravel substrates in sheltered bays with very little fluctuation in salinity, and range from intertidal to water depths of $30 \mathrm{~m}$ (Robert Blodgett, oral communication, 2004). Similar Miocene molluscan-rich sandstones have been interpreted as shallow shelf deposits in the Narrow Cape Formation near Kodiak, Alaska (Nilsen and Moore, 1979). The outsized clasts are interpreted as remnants of coarse-grained storm layers that have been disseminated by extensive bioturbation. The volcaniclastic sandstones, especially those rich in pumice fragments, suggest proximity to an active arc.

Age:

This measured section contained no organic-rich layers suitable for palynological analysis. Radiometric determined K-Ar ages from volcanic tuffs near the top of the Milky River Formation have ages of $3.53 \pm 0.27$ Ma and $3.87 \pm 0.06 \mathrm{Ma}$ (Wilson and others, 1981; Detterman and others, 1996).

\section{Reservoir Properties:}

Analysis of three sandstone samples from the Sandy Ridge measured section yielded porosities ranging from 33 to 36 percent and permeabilities ranging from 73.11 to $3553.98 \mathrm{md}$.

\section{Miscellaneous Measured Sections}

Measured stratigraphic sections discussed in this part of the report are not the main focus of our study. These sections were measured to better establish the regional stratigraphic framework of the Bristol Bay basin. Below we provide some basic observations and preliminary interpretations for these sections.

\section{Hot Springs 1 Measured Section}

\section{Location:}

This section is located along the west coast of Port Moller Bay and is labeled HS1 on figure 3.1. The GPS location for the base of the section is 55.86012\% $160.49309^{\circ}$ and it is located in the Port Moller D-2 Quadrangle. Bedding has a strike and dip of $184^{\circ} / 22^{\circ}$ SE. This outcrop has been mapped as part of the Lower Cretaceous Herendeen Formation (Detterman and others, 1996). 


\section{Lithofacies Description/Depositional Interpretation:}

This section is characterized by coarse, well sorted sandstone (fig. 3.12). Planar and trough cross stratification, and horizontal stratification are well developed in this section (fig. 3.12). Individual foresets average about $40 \mathrm{~cm}$ in thickness. Molluscan fauna, mainly Buchia, are found in all sandstones in this section, but were also found concentrated in distinct lenses (7-10 m on fig. 3.12). Trace fossils in this section are limited to horizontal burrows on bedding planes; no vertical burrows were recorded.

We tentatively interpret this section to represent deposition in mainly nearshore marine environments. This interpretation is based primarily on the dominance of horizontal stratification and planar cross stratification as well as the excellent sorting. The fossil-rich horizons are interpreted as storm layers.

\section{Harbor Point 1 Measured Section}

Location:

This section is located on the peninsula separating Port Moller Bay from Herendeen Bay and is labeled HP1 on figure 3.1. The GPS location for the base of the section is $55.86017^{\circ} / 160.59250^{\circ}$ and it is located in the Port Moller D-2 Quadrangle. Bedding has a strike and dip of $210^{\circ} / 36^{\circ}$ NW. This outcrop was reported to be oil stained in an unpublished industry report. The unit is unnamed and shown on some maps as Oligocene (?) strata.

\section{Lithofacies Description/Depositional Interpretation:}

This section consists of four main lithofacies (fig. 3.13). The lowermost part of the outcrop consists of volcanic conglomerate and breccia ( $0-8 \mathrm{~m}$ on fig. 3.13). Clasts in the conglomerate are predominantly rounded vesicular basalt clasts with average maximum clast size at $19 \mathrm{~cm}$. The conglomerate contains very little matrix.

Overlying the volcanic conglomerate are very coarse-grained sandstones interbedded with shales. The reported oil-stained sandstones are part of this lithofacies. Molluscan fossils are common on the bedding surfaces of the sandstones. Thin conglomeratic beds, less than $50 \mathrm{~cm}$ thick, containing mainly volcanic clasts, were also recorded.

A third lithofacies association defines the middle part of the section. Ripple-laminated siltstones and fine sandstones are common in this part of the section. Several millimeter-thin bentonites were also recognized in this lithofacies association. Fragments of plant fossils and woody detritus are very common.

The uppermost part of the section is dominated by thick-bedded sandstones and conglomerates. These units have horizontal stratification and trough cross stratification. The conglomerates are dominated by volcanic clasts, and locally volcanic bombs have been incorporated into the sandstones.

We tentatively interpret this section to represent volcanic and sedimentary deposition on a marine shelf

adjacent to a volcanic arc. The amount of volcanic detritus in this section suggests that it is not part of the Bear Lake Formation. The section is more similar to the Milky River Formation. 


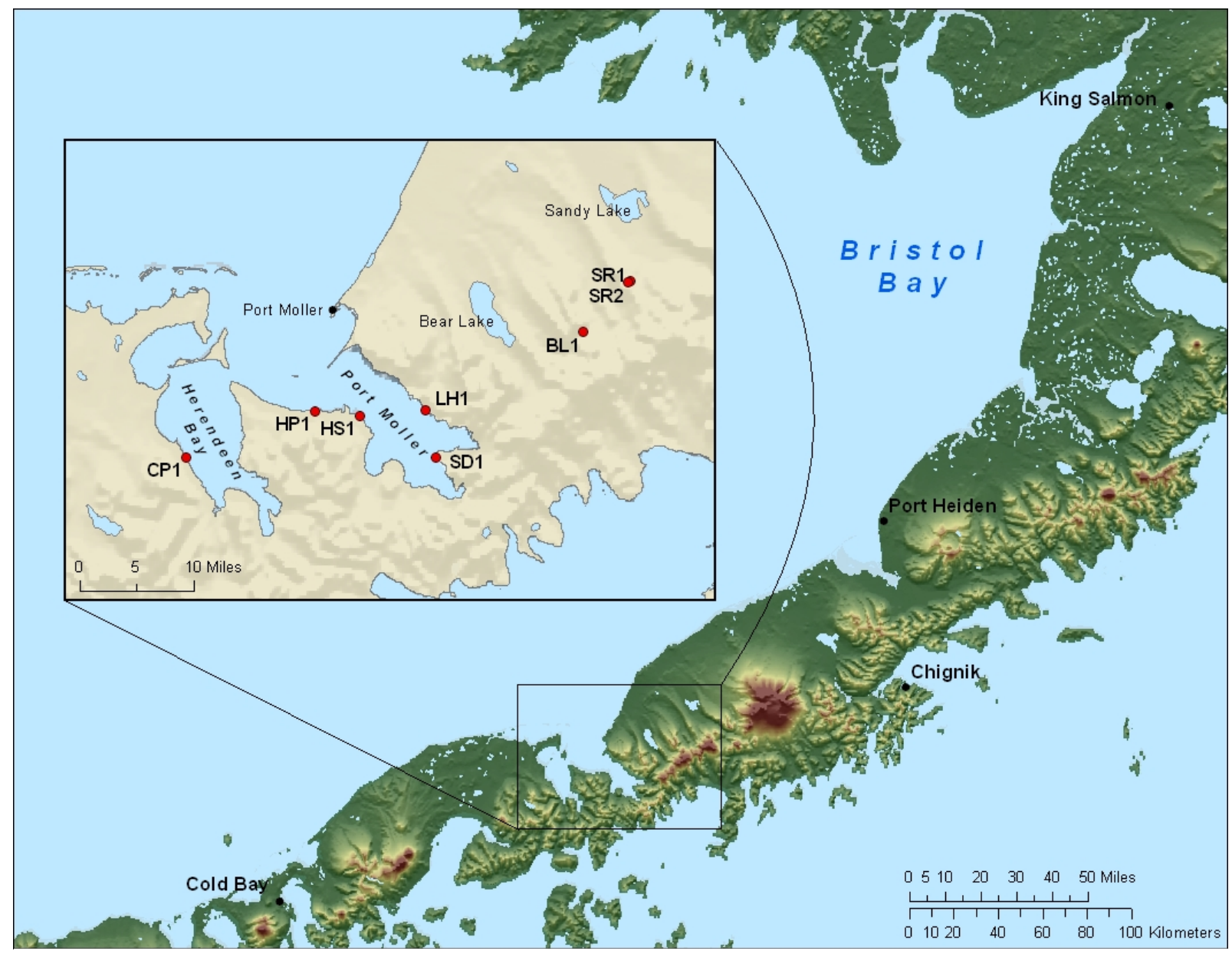

Figure 3.1. Generalized map of the Bristol Bay and Alaska Peninsula areas, showing location of study area and measured sections. 


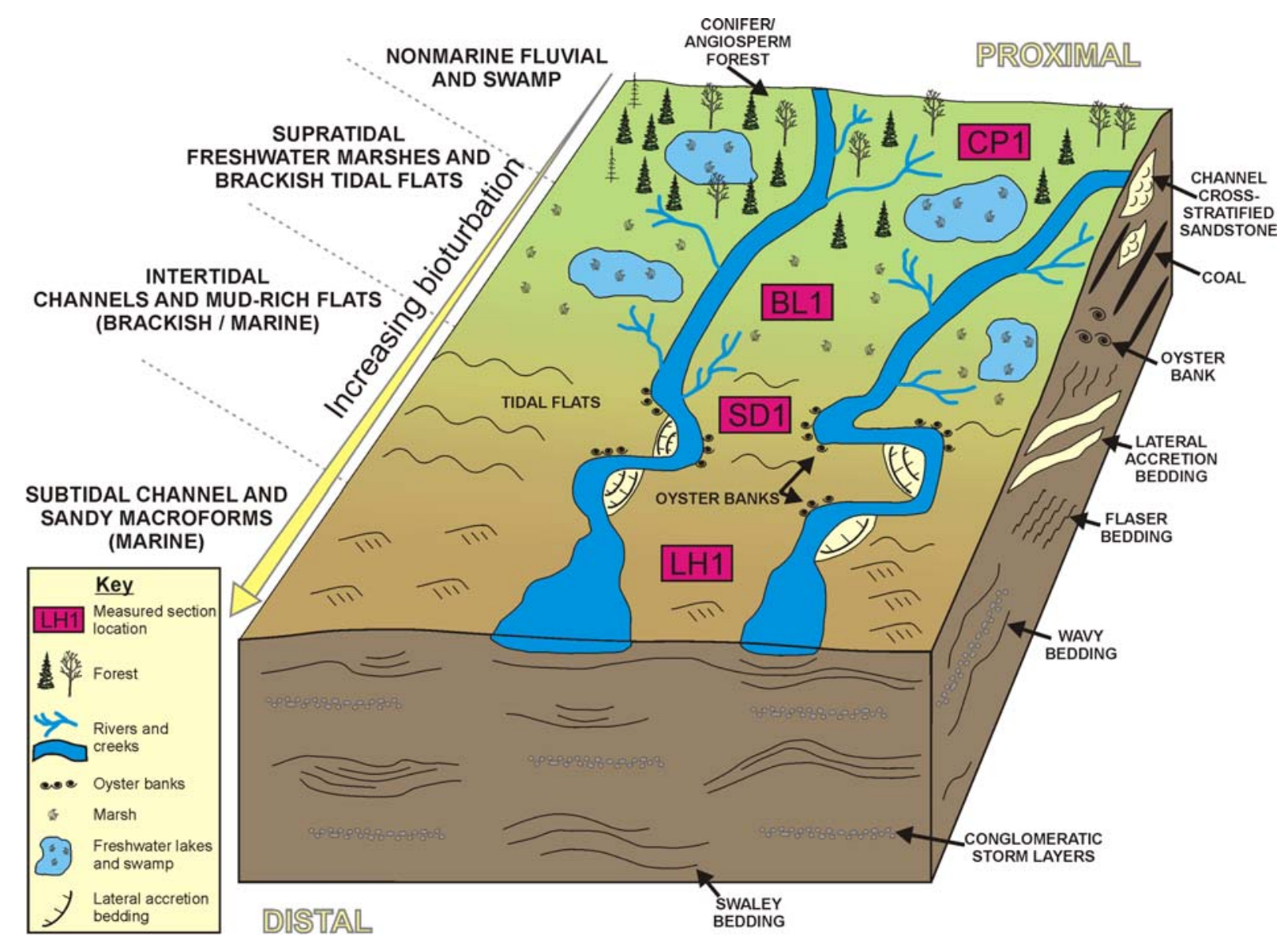

Figure 3.2. Block diagram illustrating interpreted depositional environments for measured sections in the Bear Lake Formation. 
Coal Point 1 (CP1)

Nonmarine

Fluvial/Swamp Environments

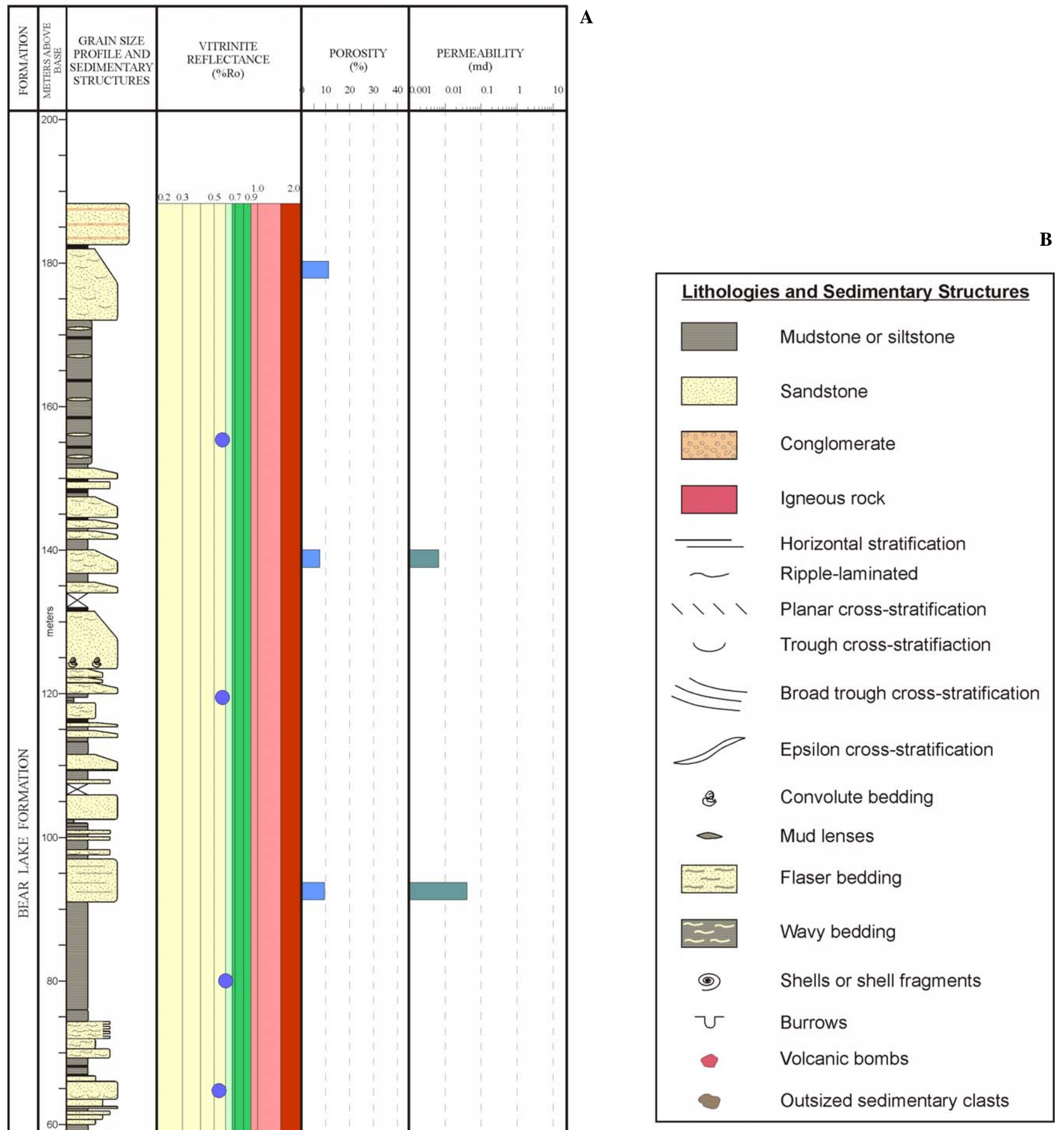

Figure 3.3. A) Coal Point 1 measured section, Bear Lake Formation. Lithic intervals, vitrinite reflectance, and porosity and permeability results are shown for section. B) Key for all measured sections. 
Figure 3.4A. Bottom of Coal Point 1 measured section, highly bioturbated silty sandstone, coin for scale.
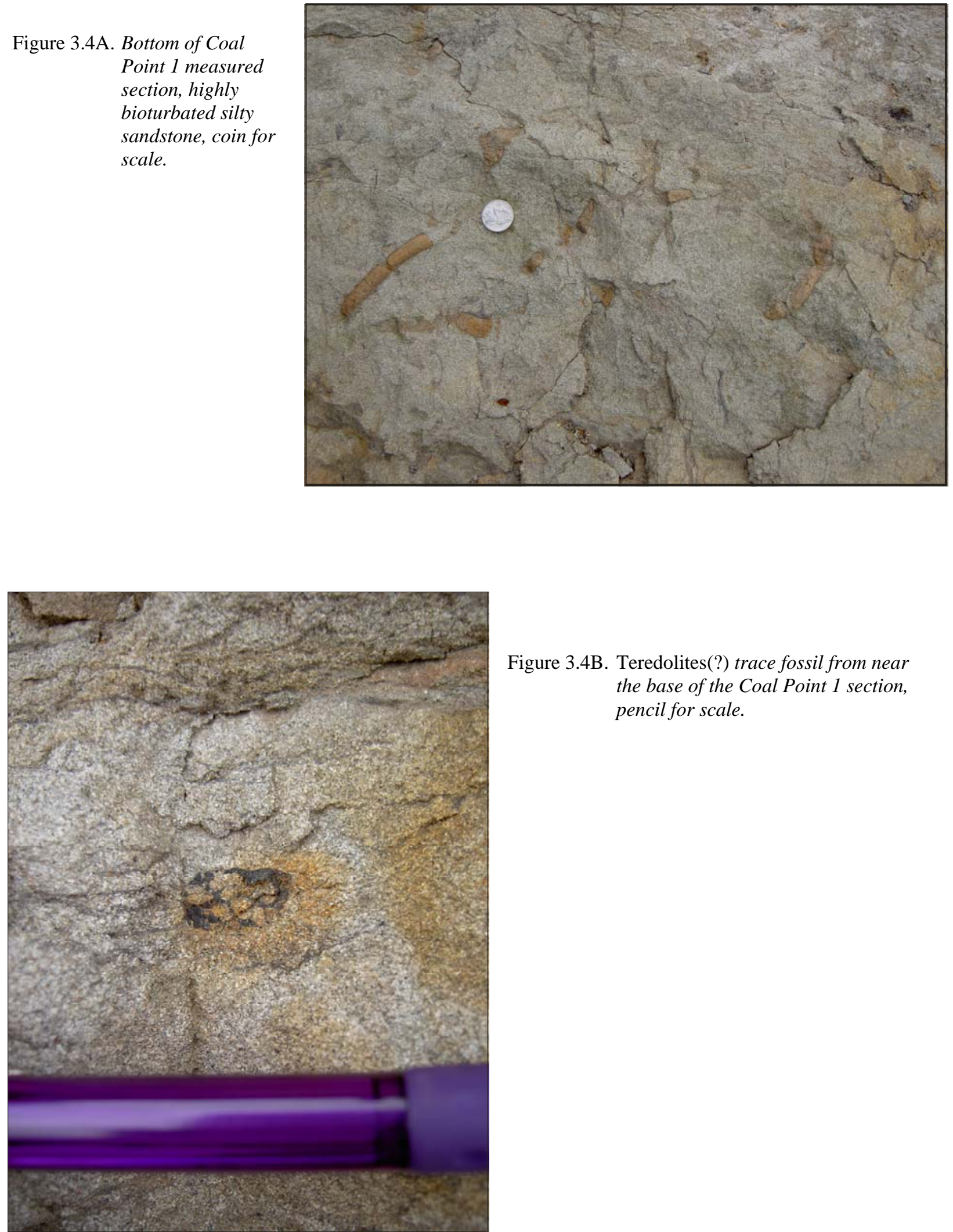

Figure 3.4B. Teredolites(?) trace fossil from near the base of the Coal Point 1 section, pencil for scale. 
Figure 3.4C. Interbedded sandstone and coal from the middle of the Coal Point 1 section; geologist for scale.
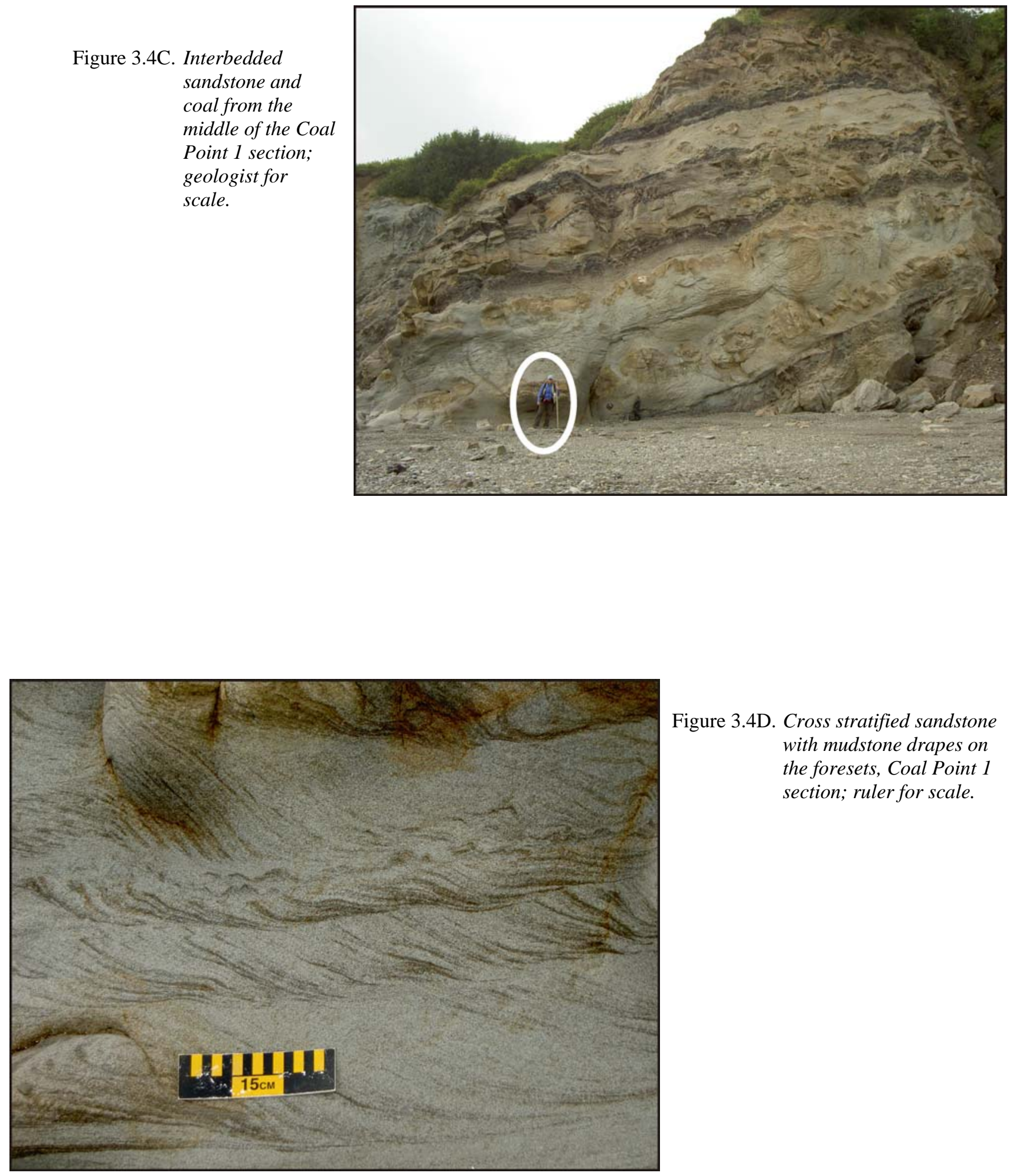

Figure 3.4D. Cross stratified sandstone with mudstone drapes on the foresets, Coal Point 1 section; ruler for scale. 


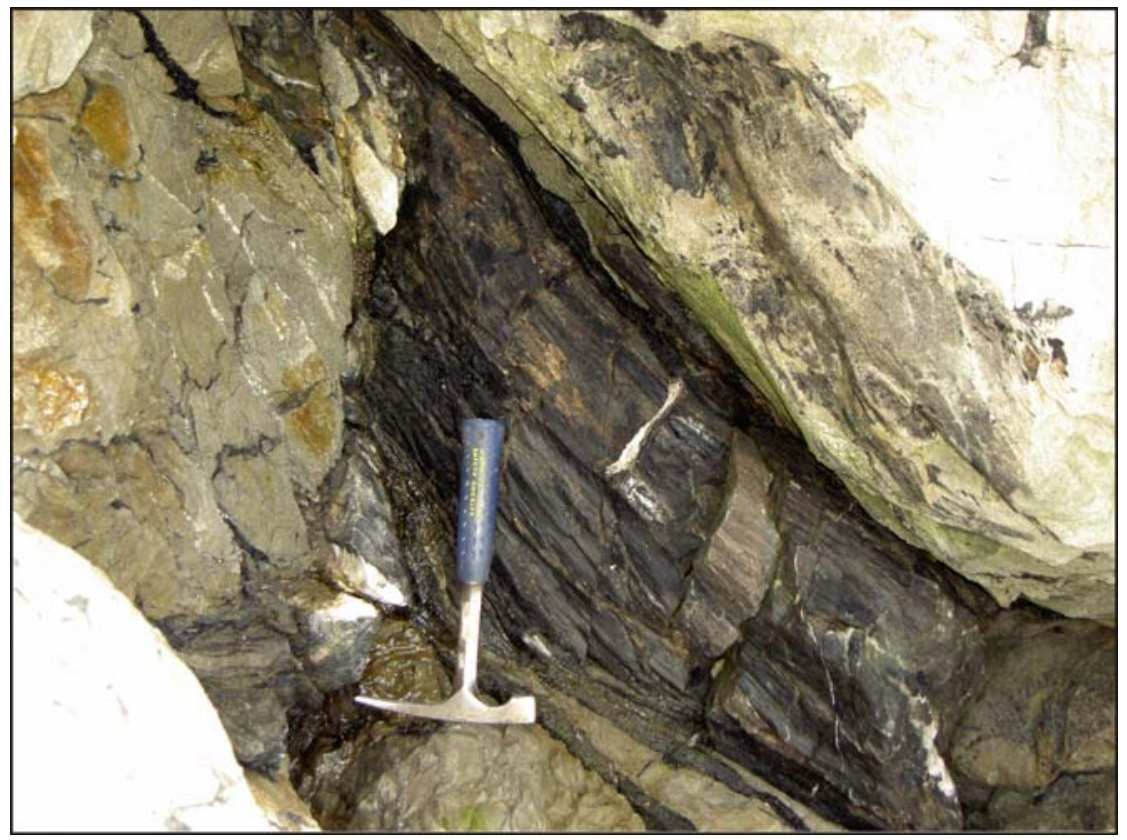

Figure 3.4E. Large tree trunk from near the top of the Coal Point 1 section, hammer for scale.

Figure 3.4F. Trunk (red arrow) to roots (white arrows) transition, from Coal Point 1 section, coin for scale.

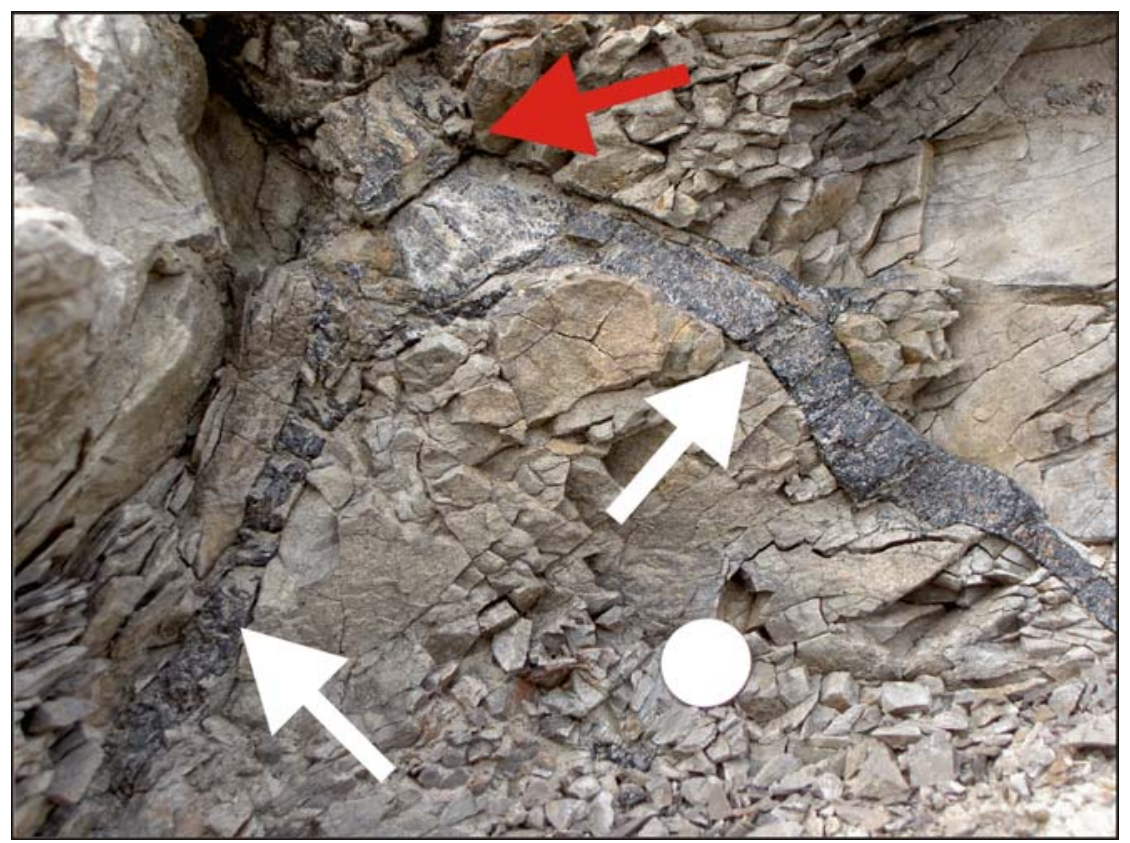


BEAR LAKE 1 (BL1)

Freshwater Marshes/Supratidal Brackish Tidal Flats

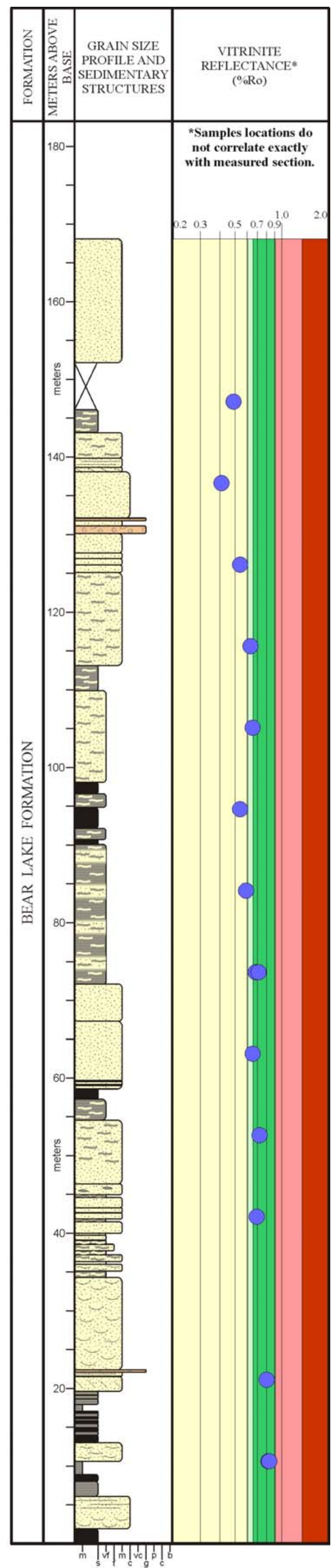

Figure 3.5. Bear Lake 1 measured section, Bear Lake Formation. Lithic intervals and vitrinite reflectance results are shown for section. See figure 3.3A for key to measured section. 


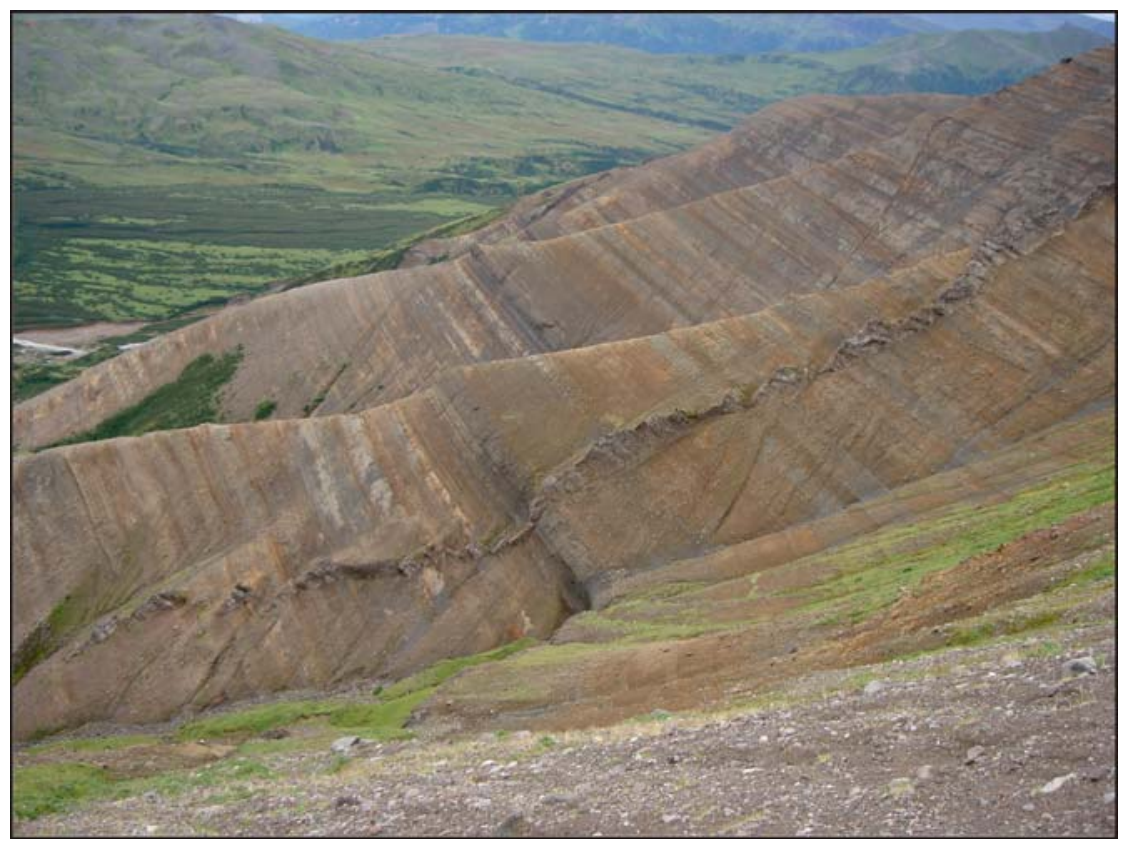

Figure 3.6A. View toward the southwest of the middle part of the Bear Lake 1 measured section.

Figure 3.6B. Trough crossstratified sandstone below horizontallystratified sandstone, capped by a pebble lag, Bear Lake 1 section. Note carbonaceous material on foresets and hammer for scale.

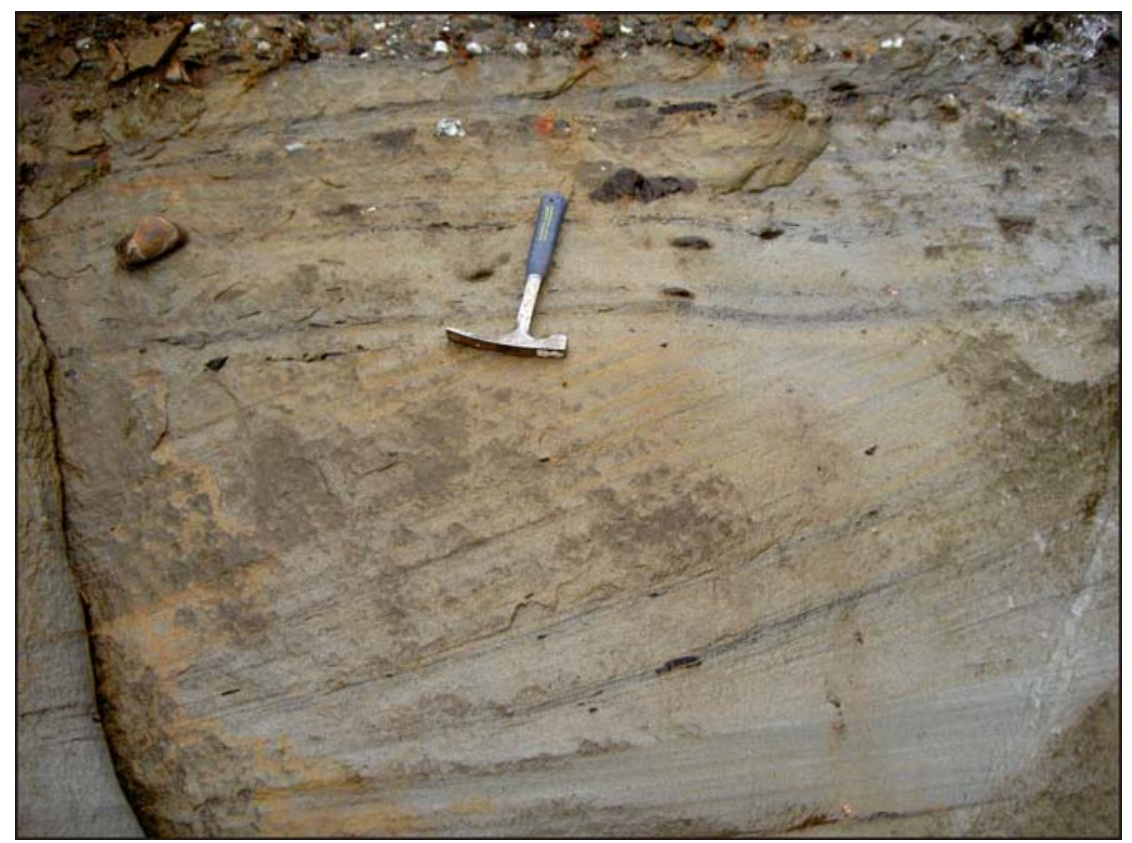




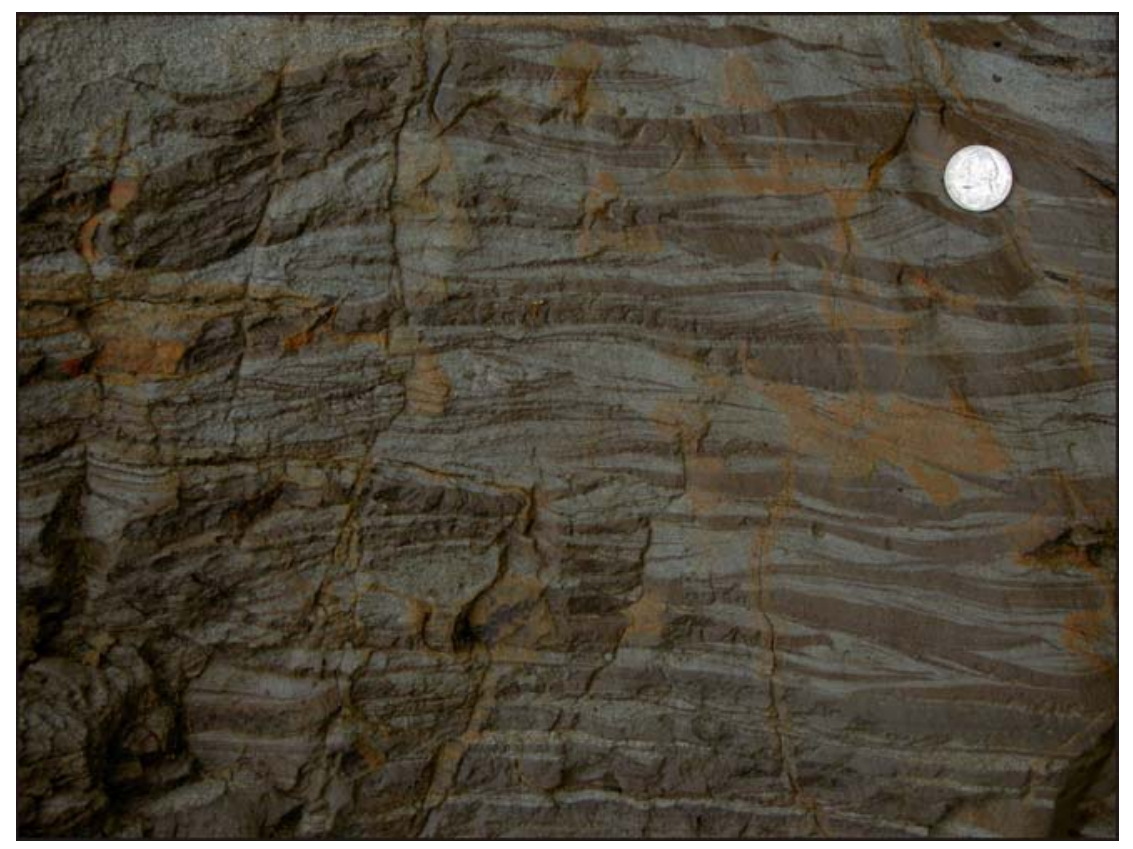

Figure 3.6C. Wavy and flaser bedding are typical of the Bear Lake 1 section. See coin for scale.

Figure 3.6D. Flaser bedding is common throughout the Bear Lake 1 section. Hammer for scale.

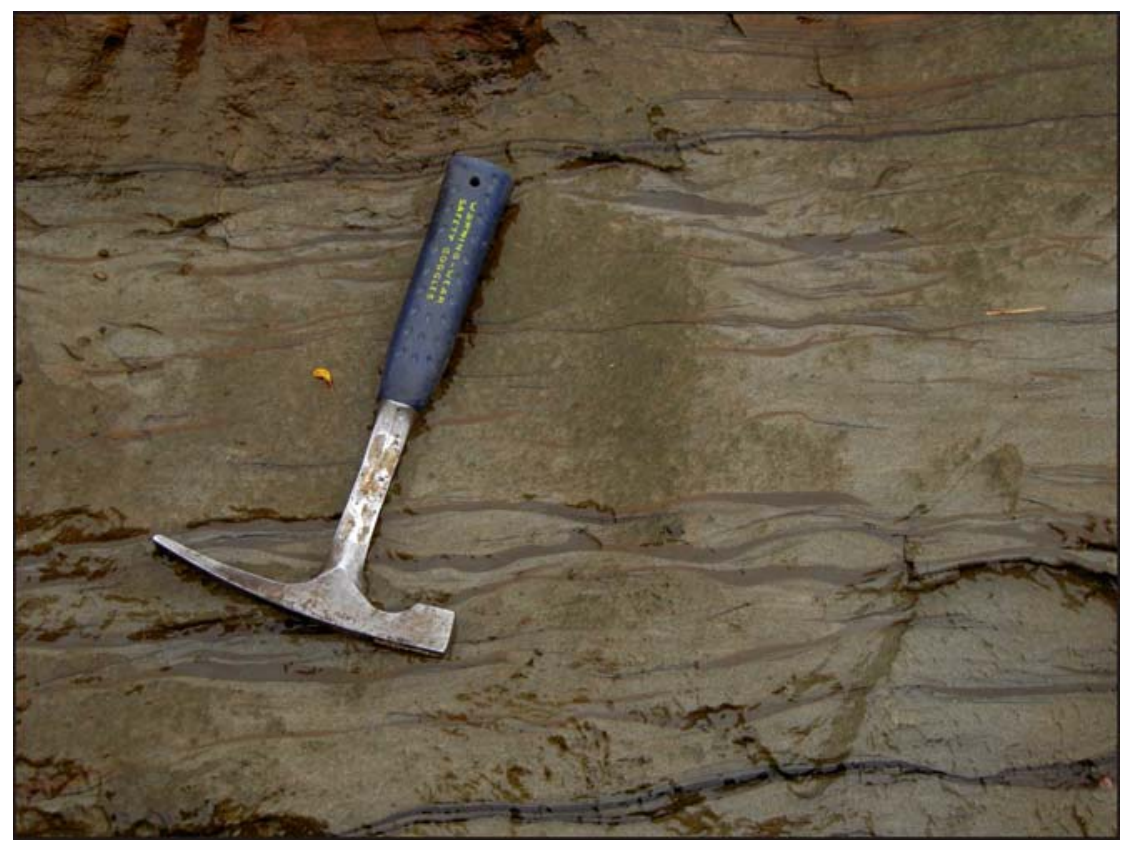




\section{SUNDEAN 1 (SD1)}

\section{Intertidal (Brackish/Marine) \\ Channels and Mud/Sand Flats}

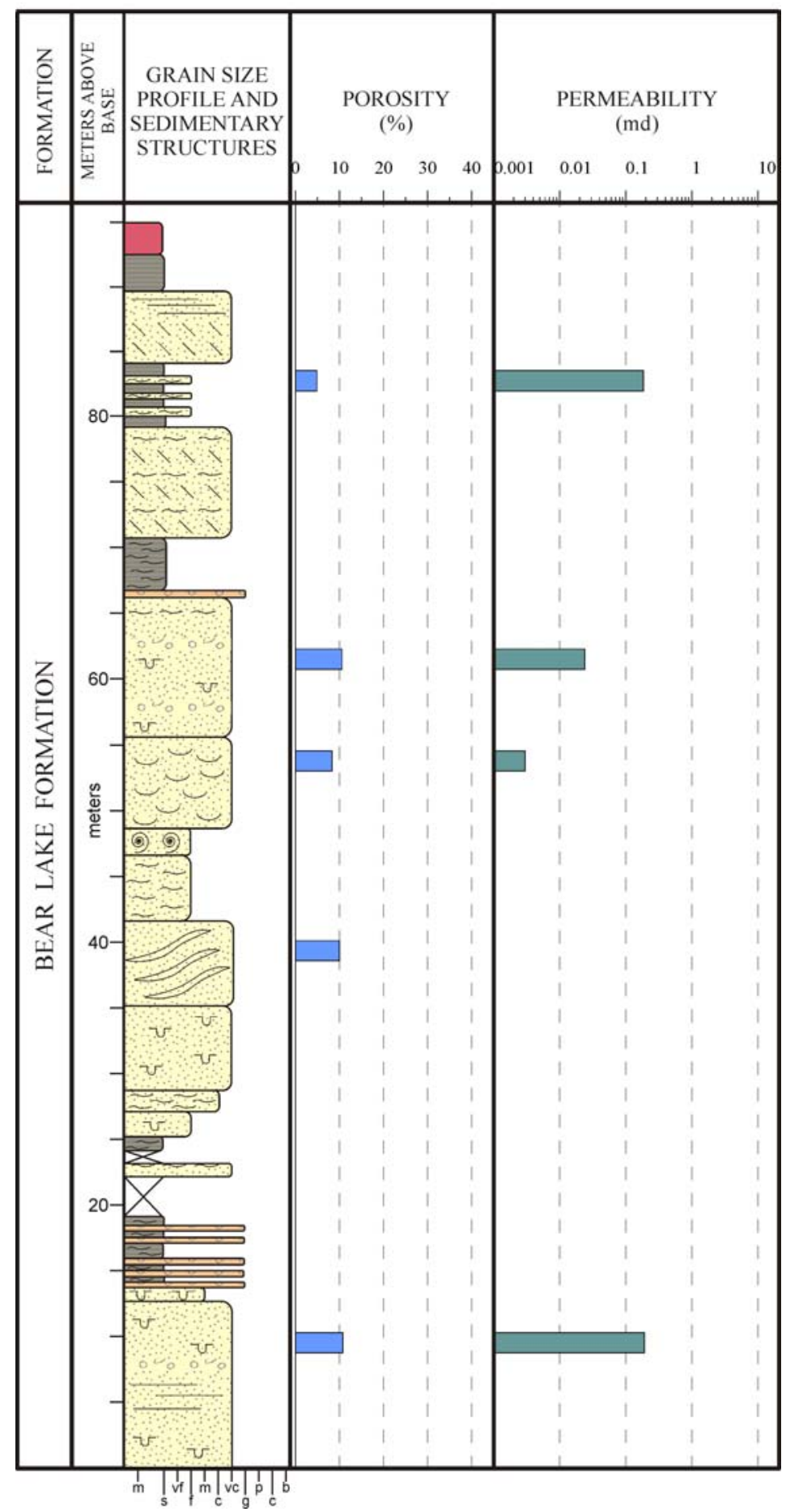

Figure 3.7. Sundean 1 measured section, Bear Lake Formation. Lithic intervals and porosity and permeability results are shown for section. See figure 3.3A for kev to measured section. 


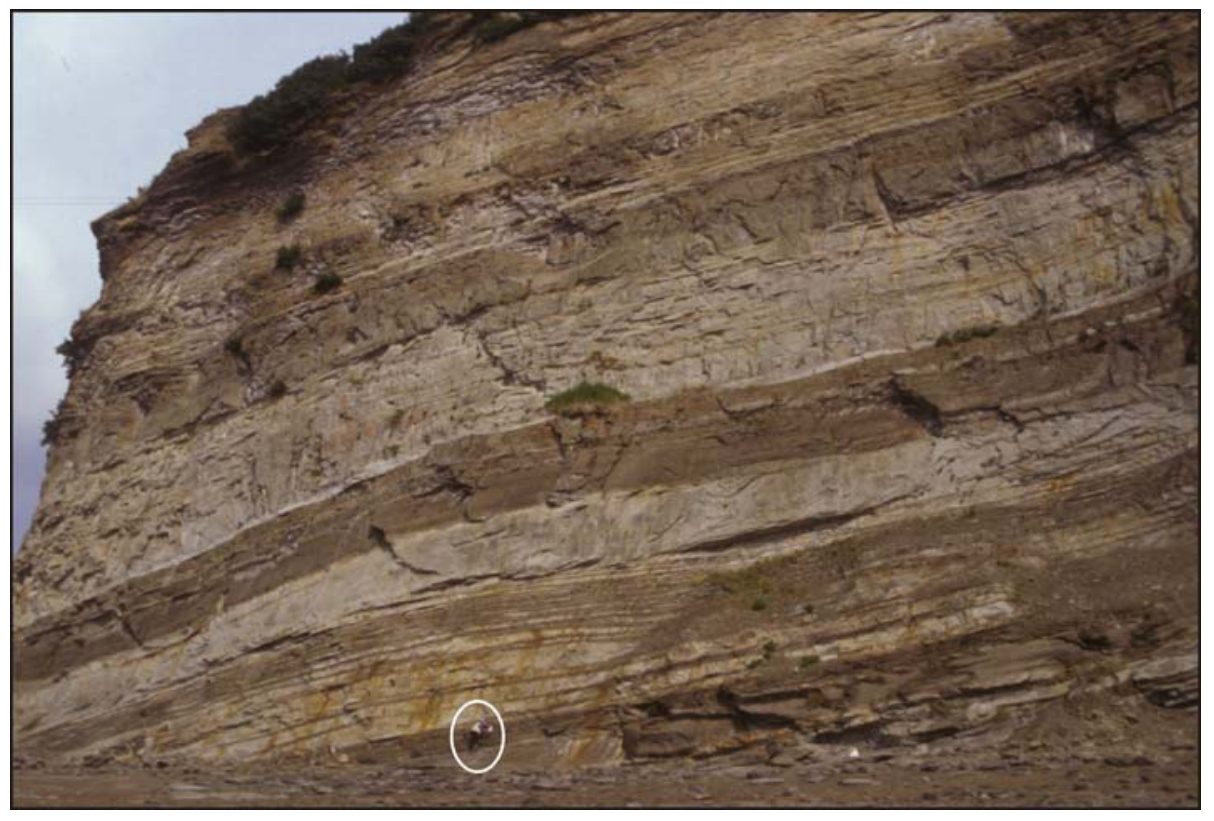

Figure 3.8A. Lateral accretionary

surfaces in

sandstone of the

Sundean 1 section.

Geologist in white

circle for scale.

Figure 3.8B. Down dip pinch out of lateral accretionary surfaces in sandstone of the Sundean 1 section. Geologist for scale.

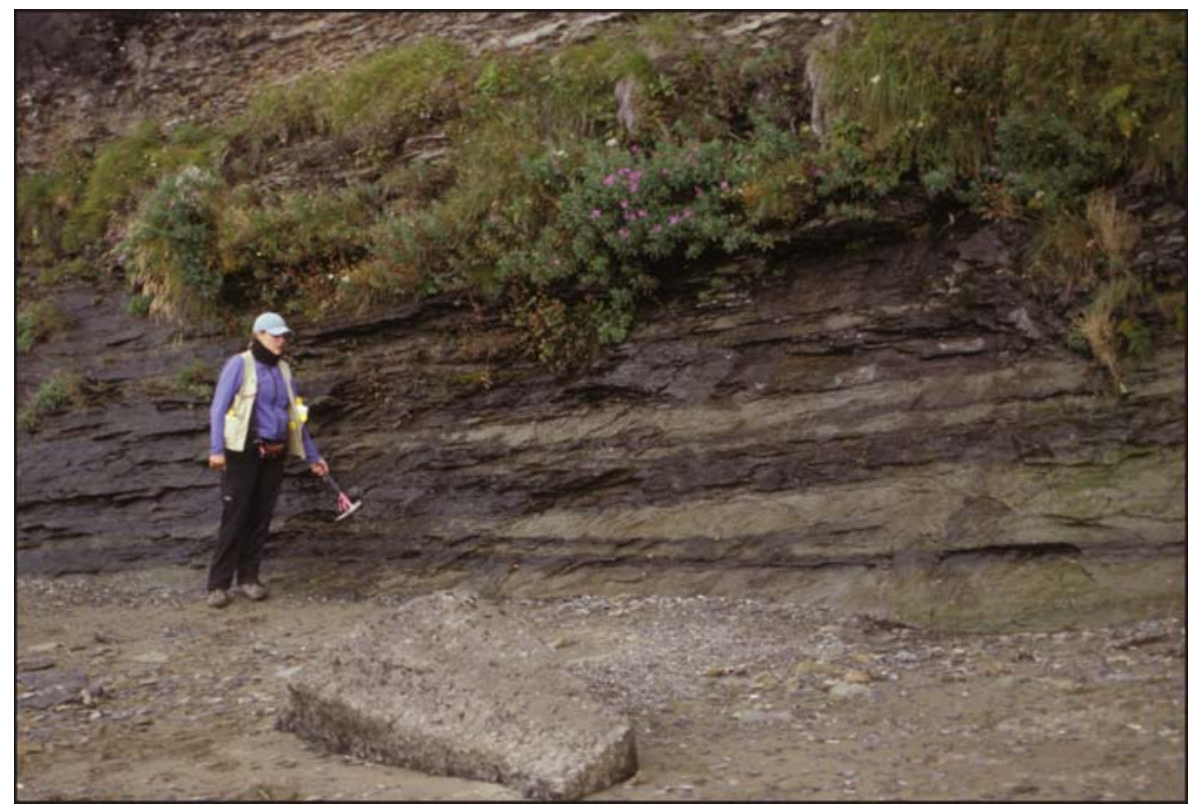




\section{LEFT HEAD 1 (LH1)}

Subtidal (Marine) Channels/ Sand Flats and Ridges

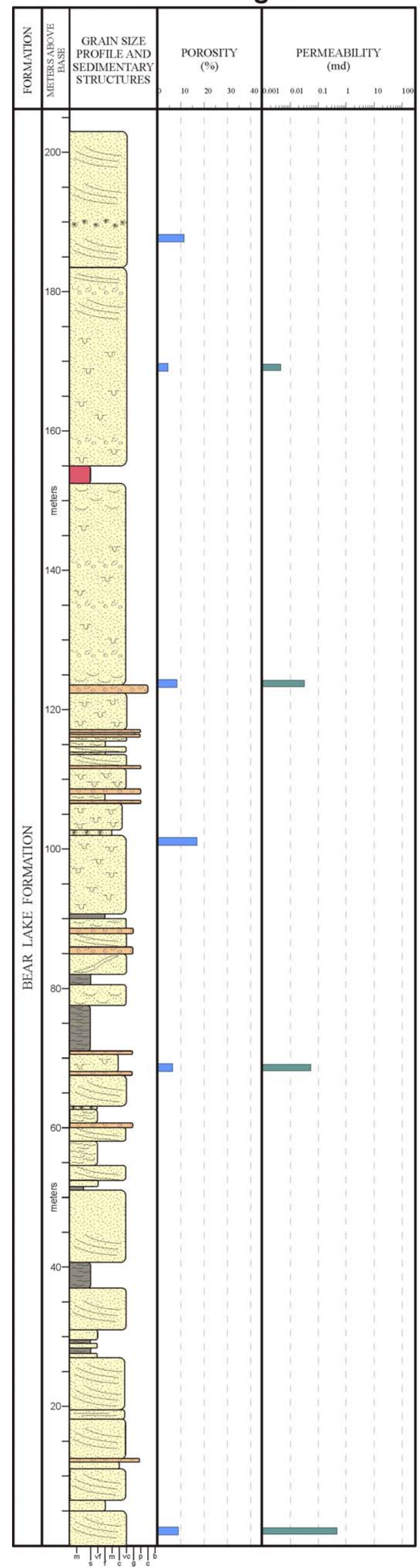

Figure 3.9. Left Head 1 measured section, Bear Lake Formation. Lithic intervals and porosity and permeability results are shown for section. See Figure 3.3A for key to measured section.

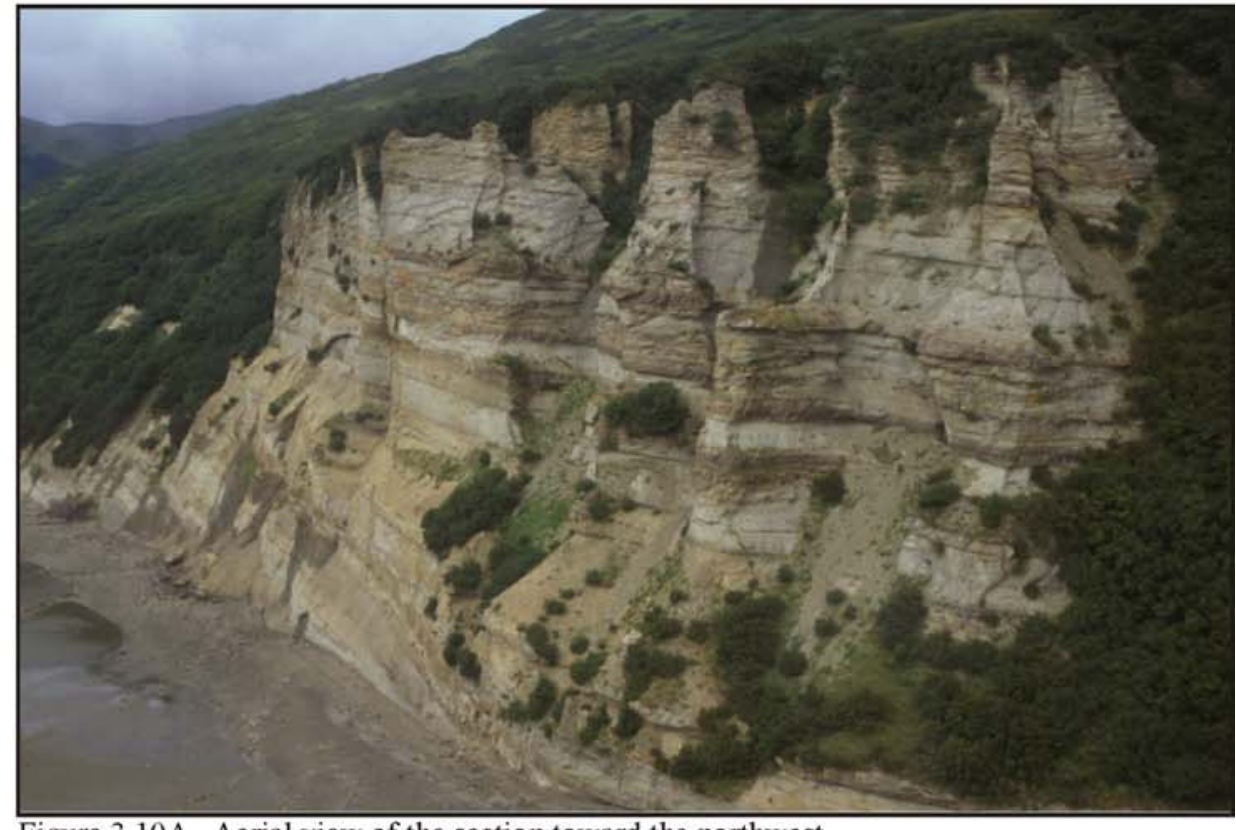

Figure 3.10A. Aerial view of the section toward the northwest.

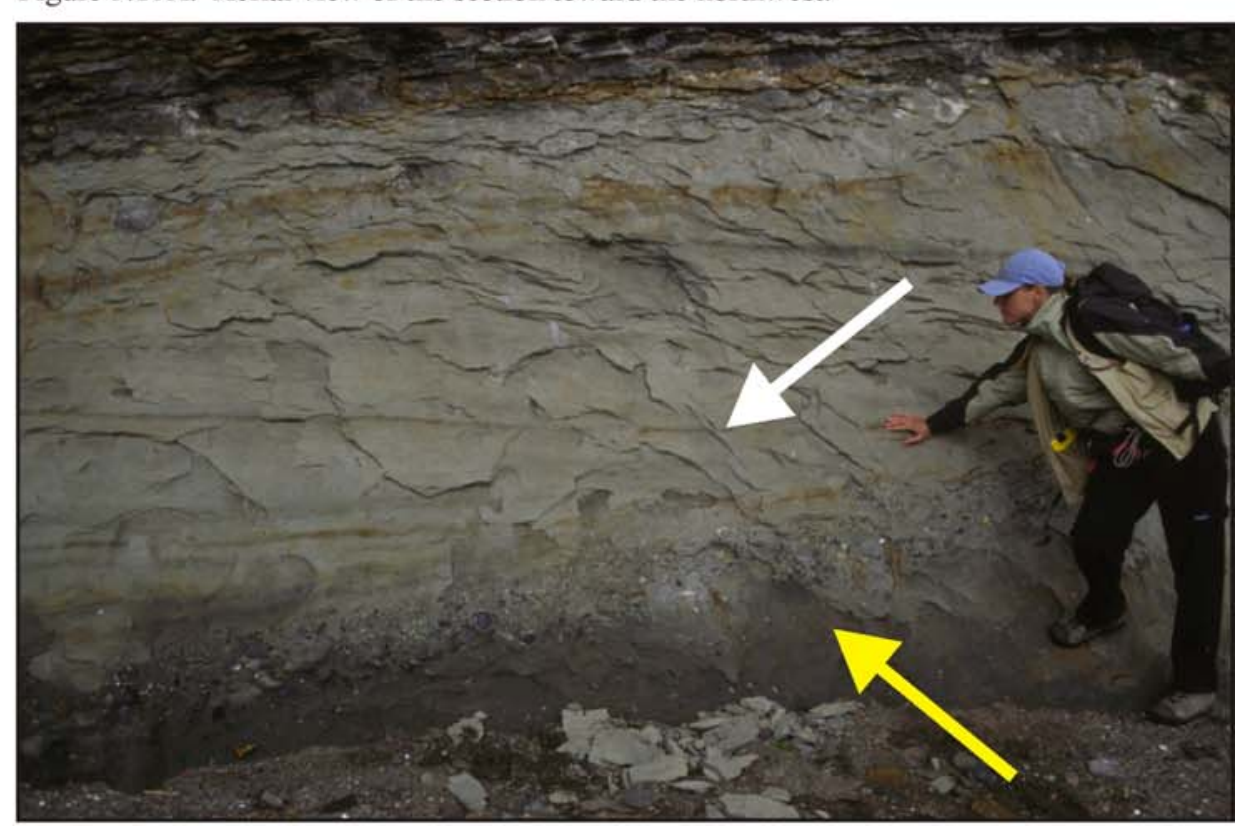

Figure 3.10B. Mudstone drapes on sandstone foresets (white arrow). Note coarse-grained storm layer (yellow arrow)

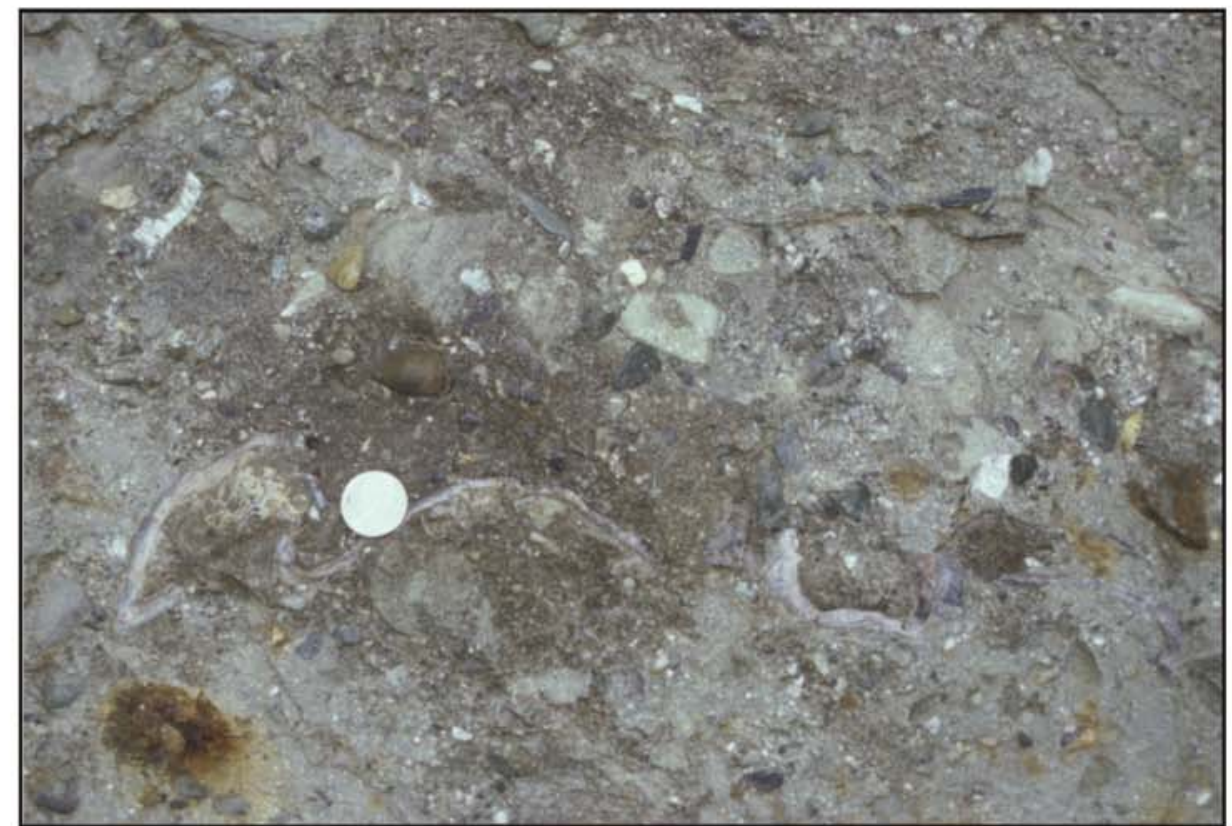

Figure 3.10C. Disarticulated mollusk fragments with outsized clasts in a sandy matrix.

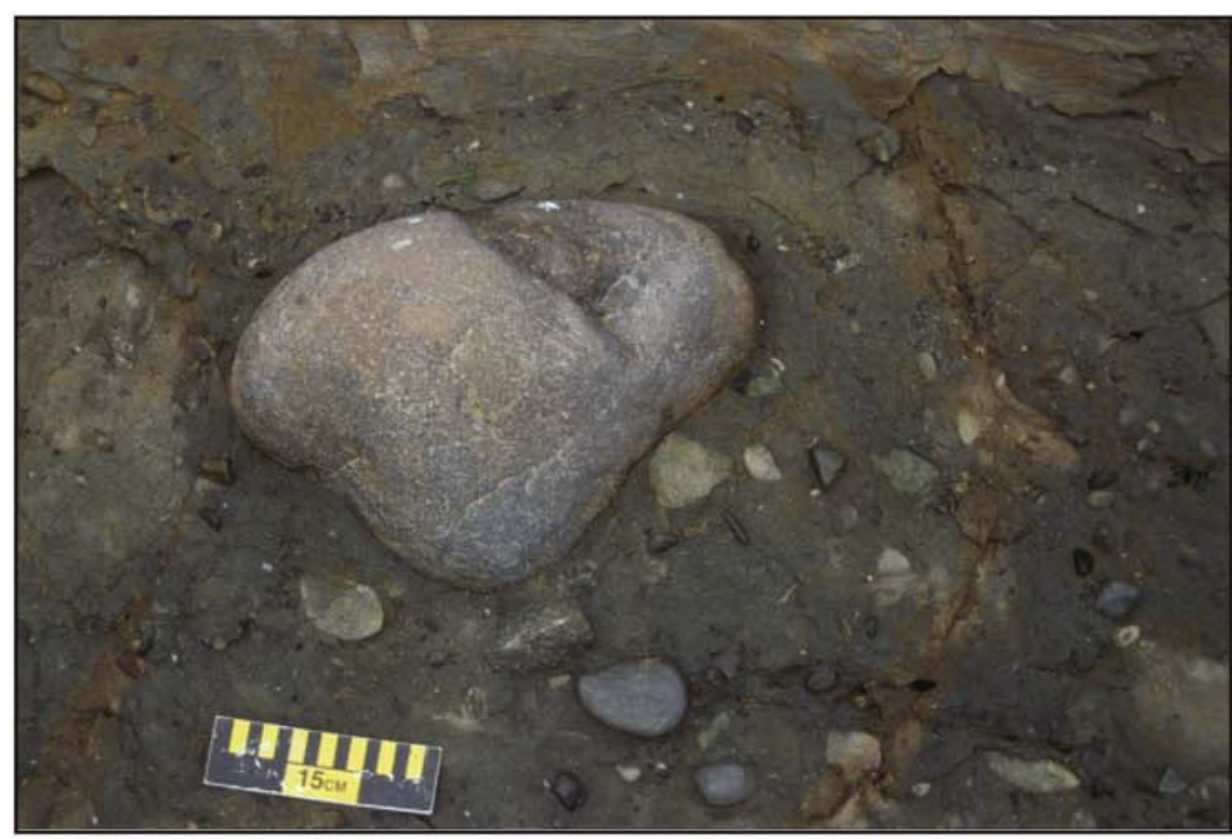

Figure $3.10 \mathrm{D}$. Outsized clast in a storm bed. 
SANDY RIDGE 1 \& 2 (SR1 \& SR2)

Open marine shelf adjacent to an active volcanic arc

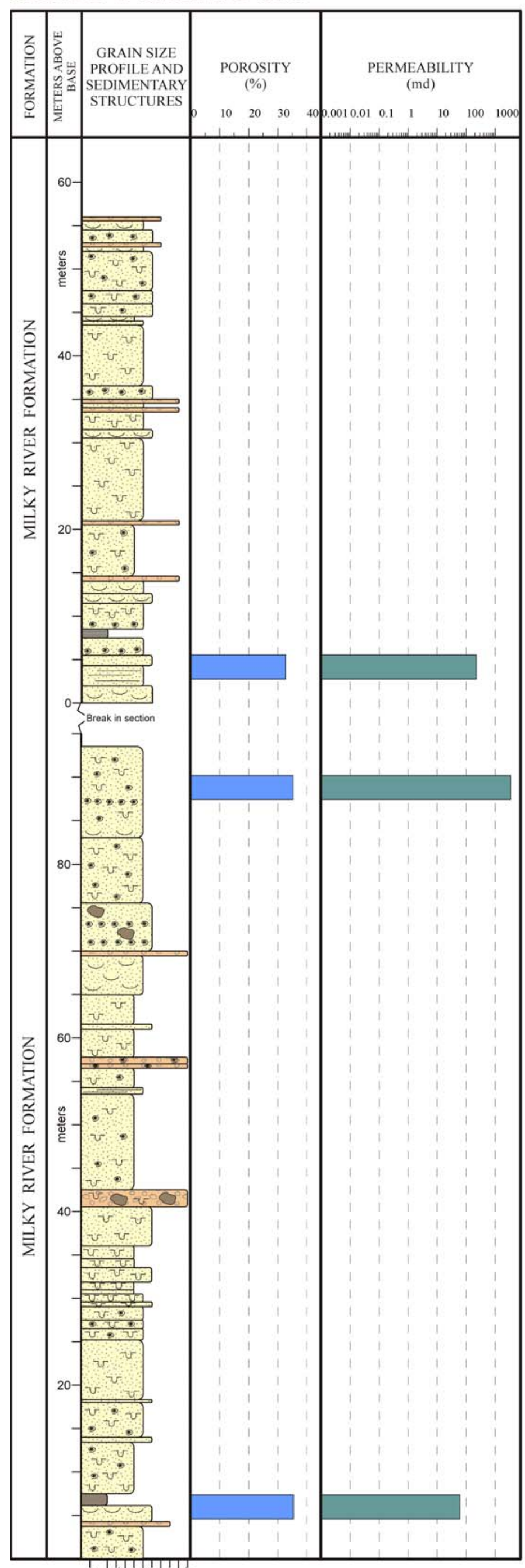

Figure 3.11. Sandy Ridge composite measured section, Milky River Formation.
Lithic intervals and porosity and Lithic intervals and porosity and permeability results are shown for section. See figure 3.3A for key to measured section. 
Figure 3.12A. Excellent exposure of mollusk-rich intervals (red arrows) in bioturbated sandstone of the Sandy Ridge section. Geologist for scale.
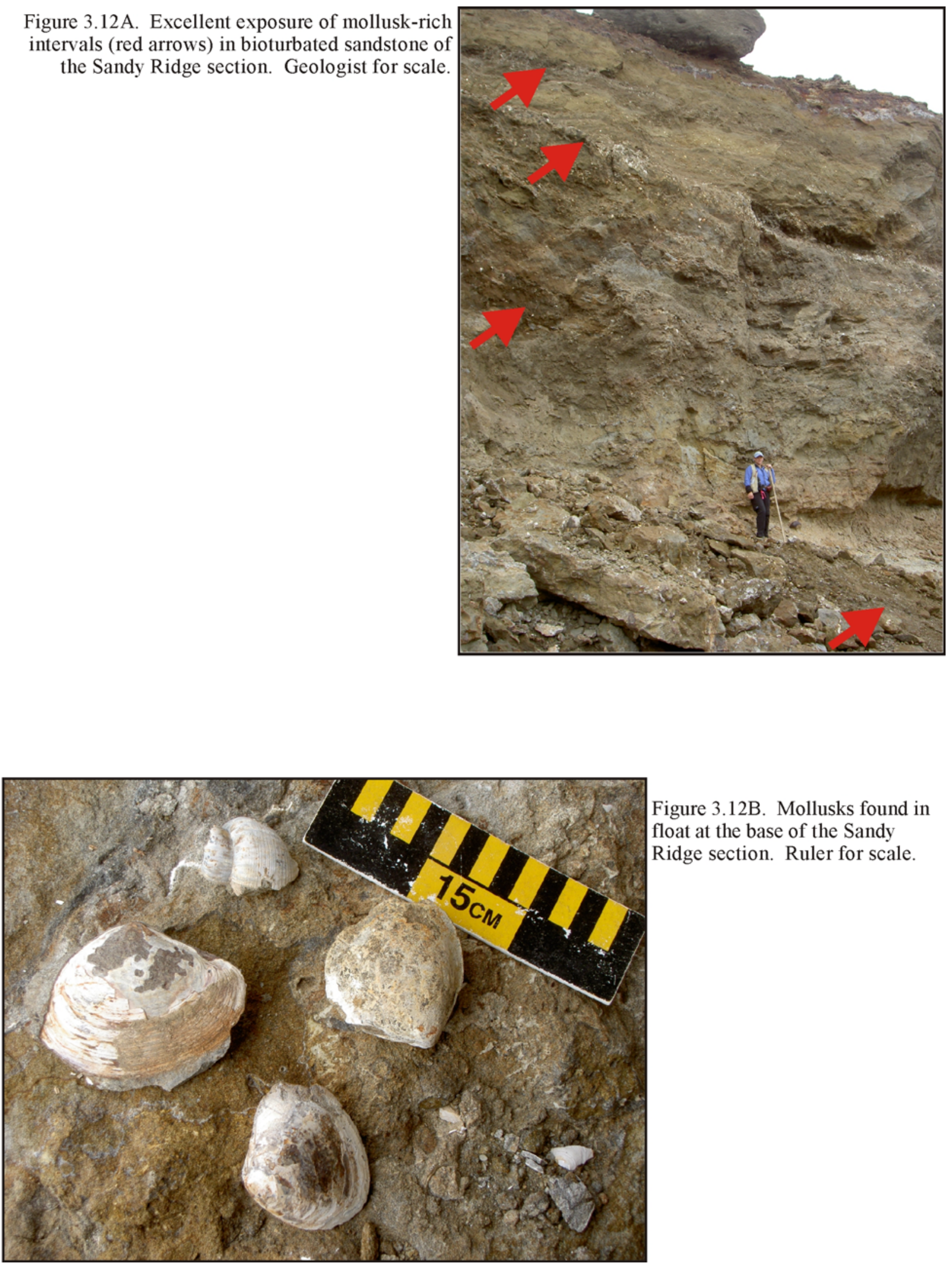

Figure 3.12B. Mollusks found in float at the base of the Sandy Ridge section. Ruler for scale. 


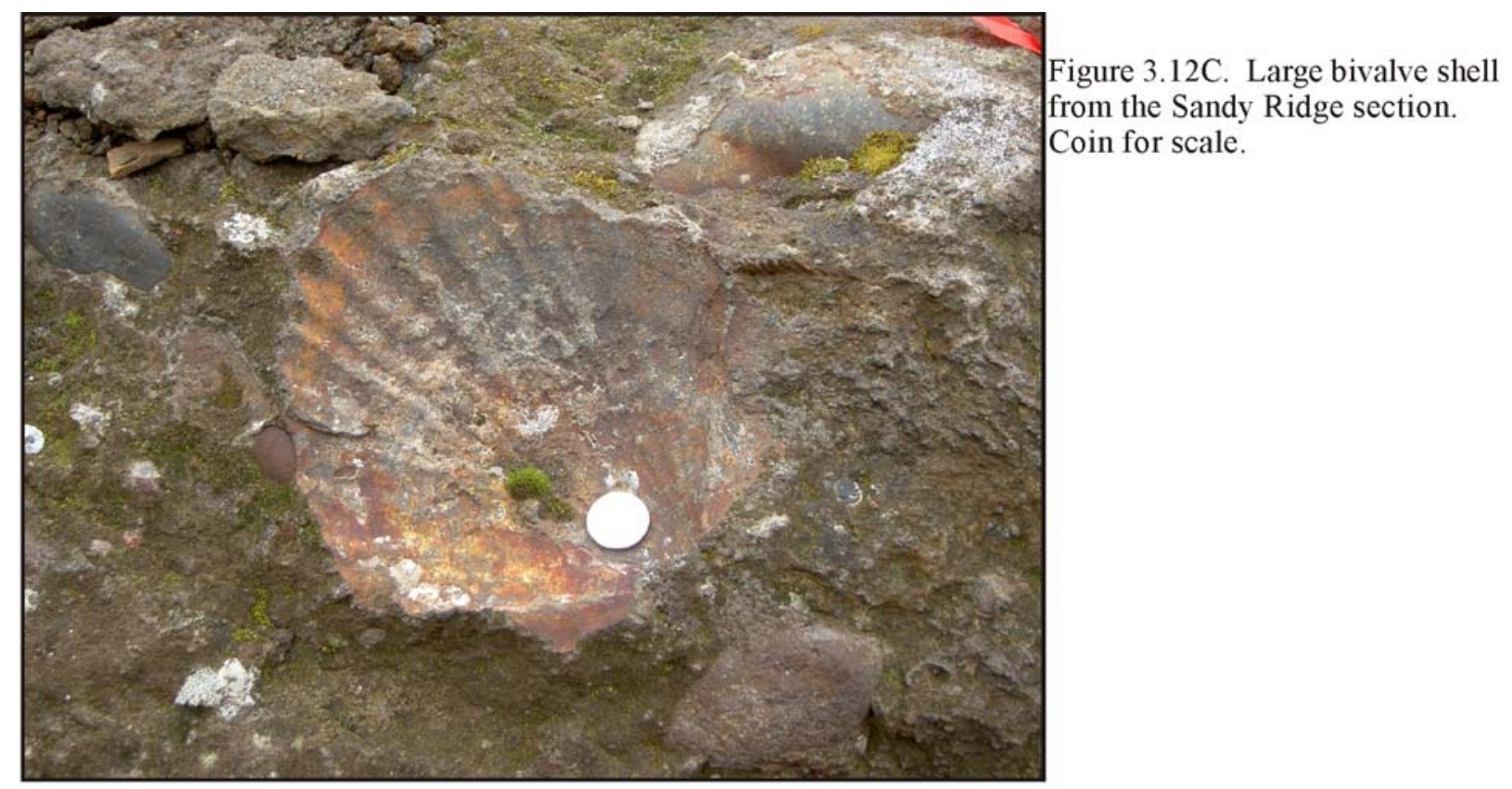

Figure 3.12D. In situ bivalves from the Sandy Ridge section. Hammer for scale.

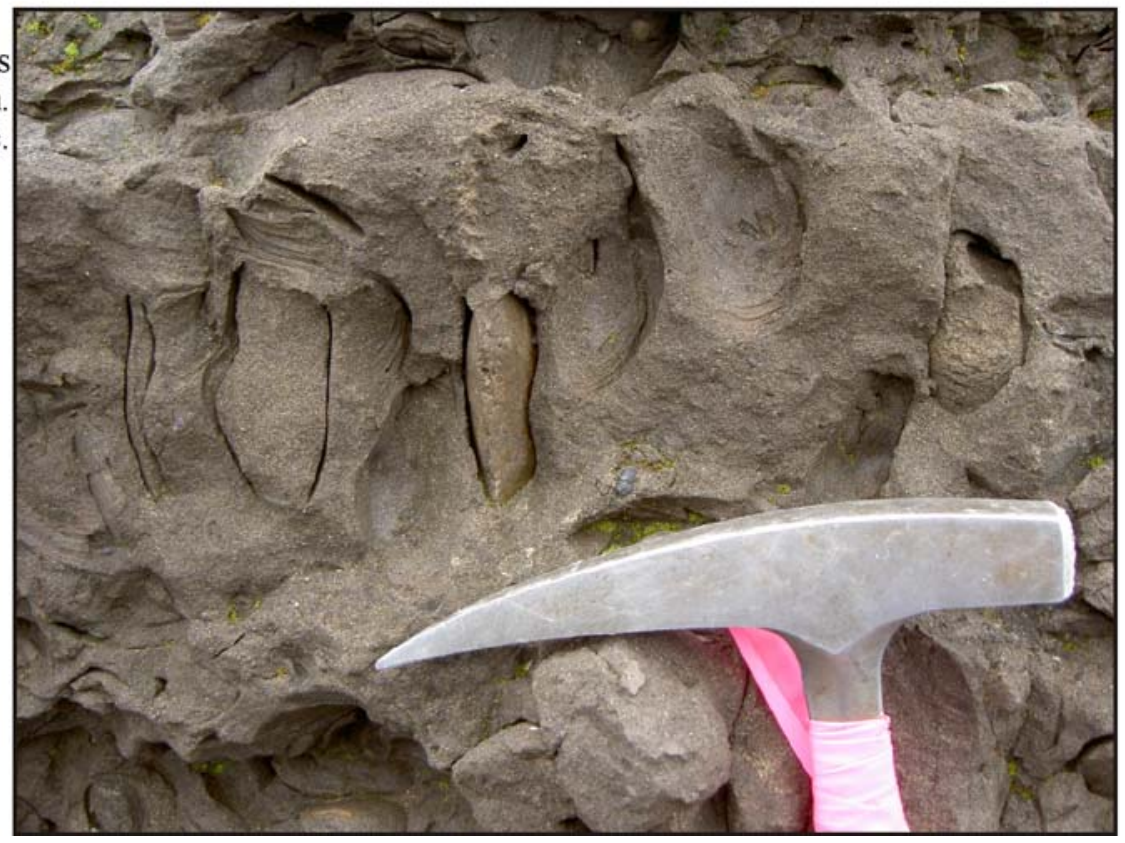




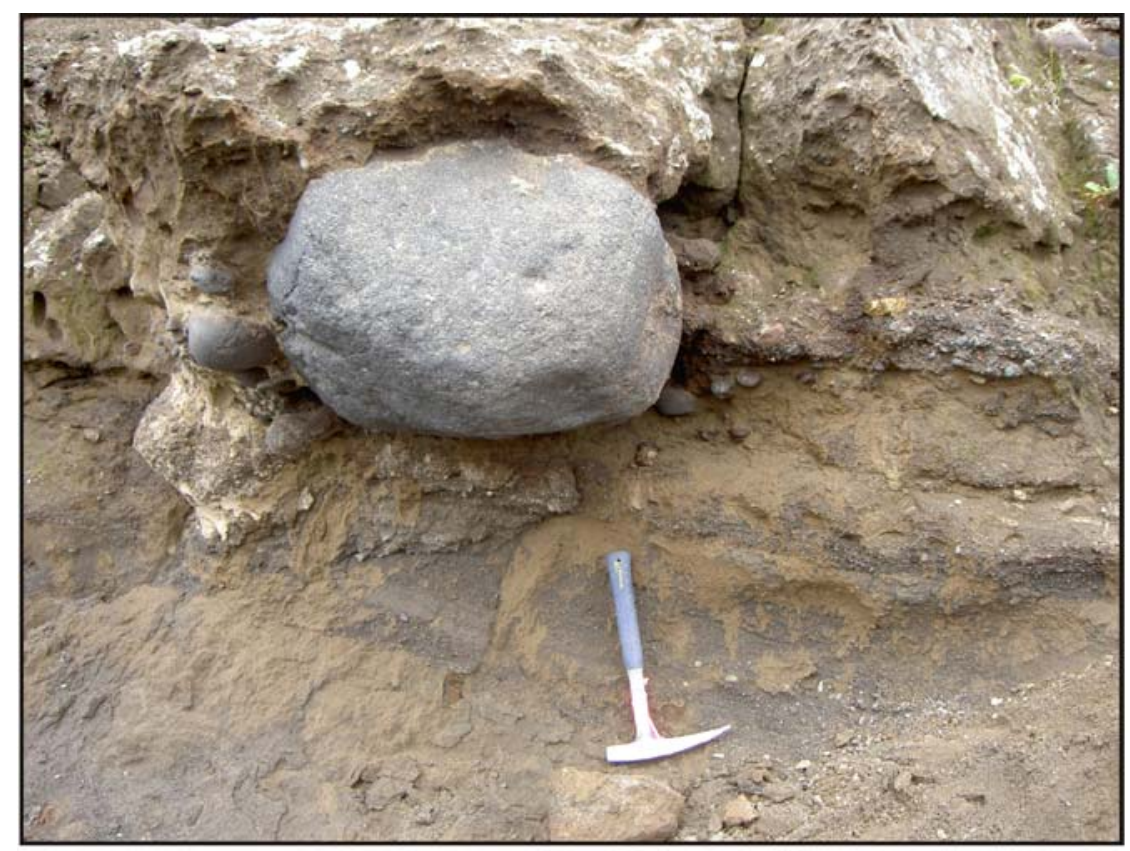

Figure 3.12E. Outsized clast in sadnstone of the Sandy Ridge section. Hammer for scale.

Figure 3.12F. Pumice-rich sandstone horizon with horizontal stratification in the Sandy Ridge section.

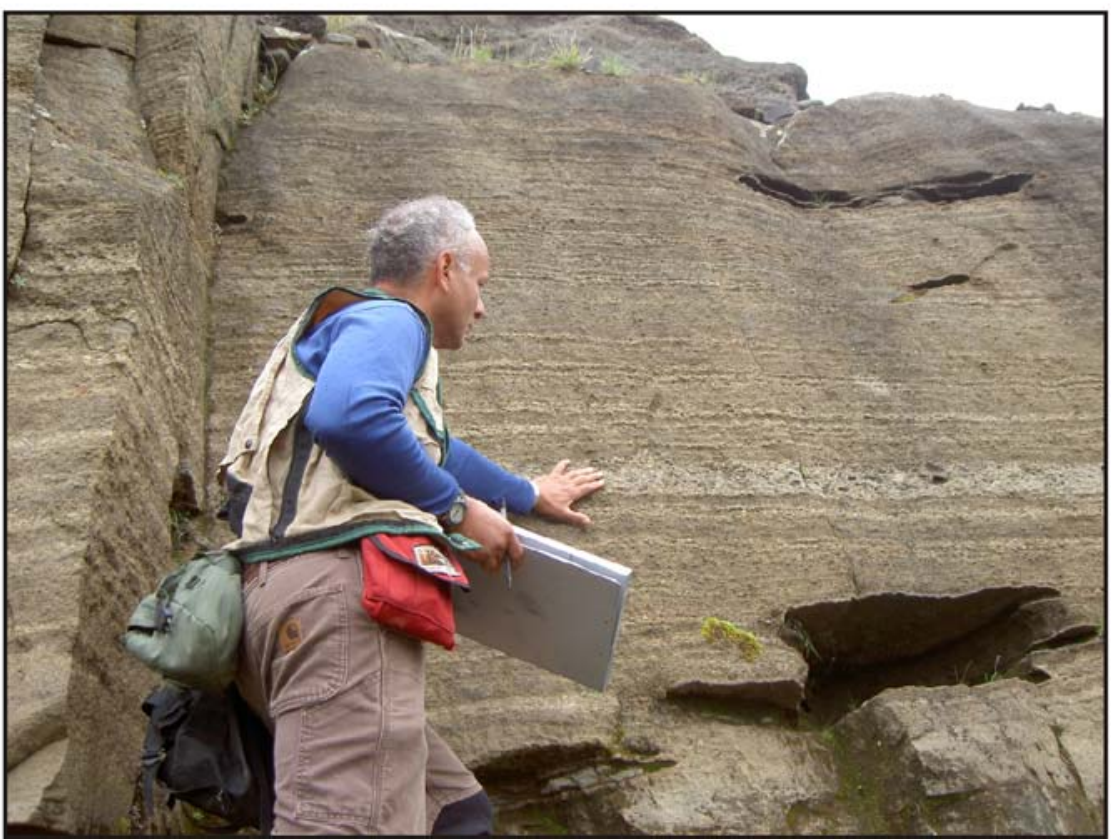




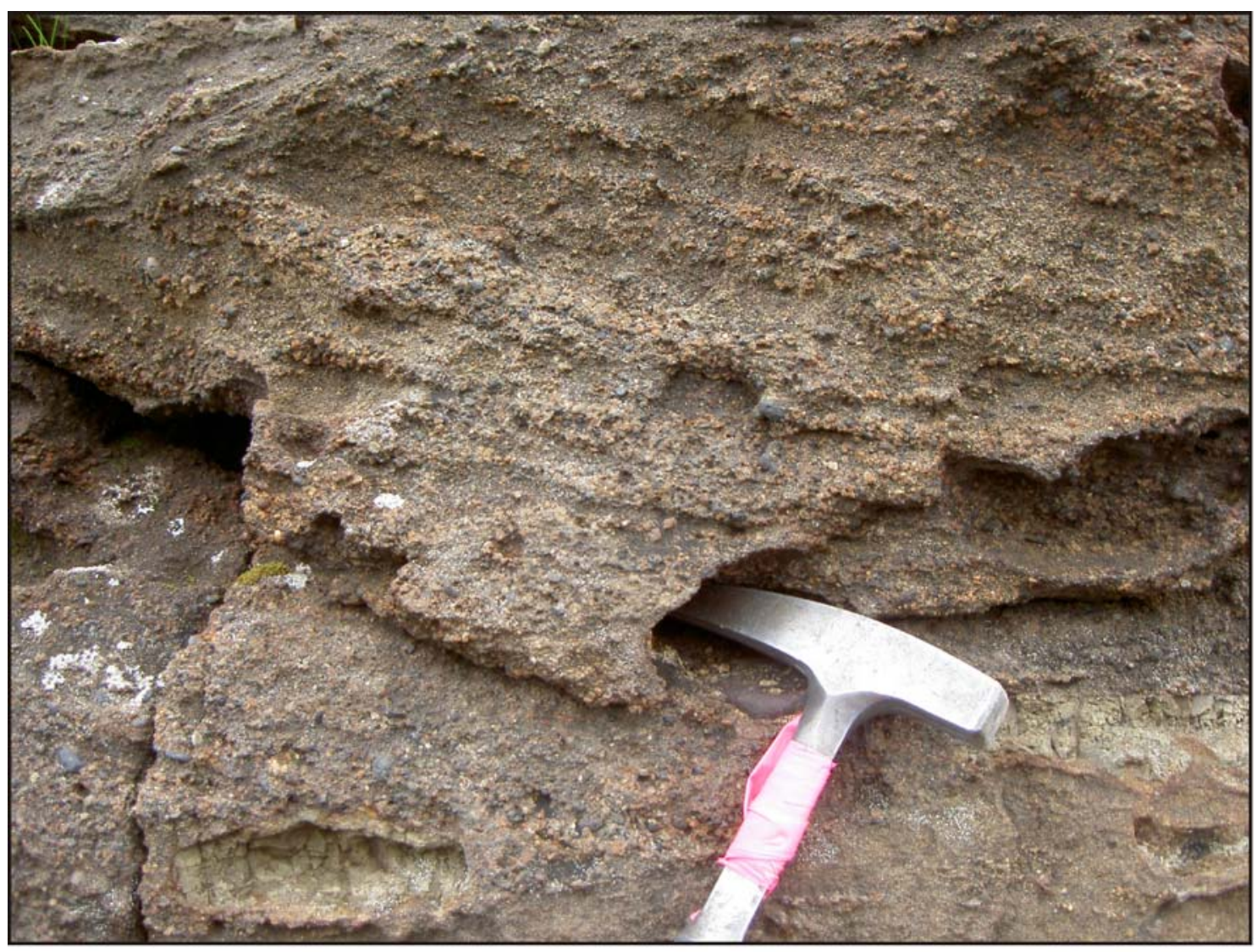

Figure 3.12G. Trough cross stratification in the pumice-rich red and black sandstone of the Sandy Ridge section. Hammer for scale. 


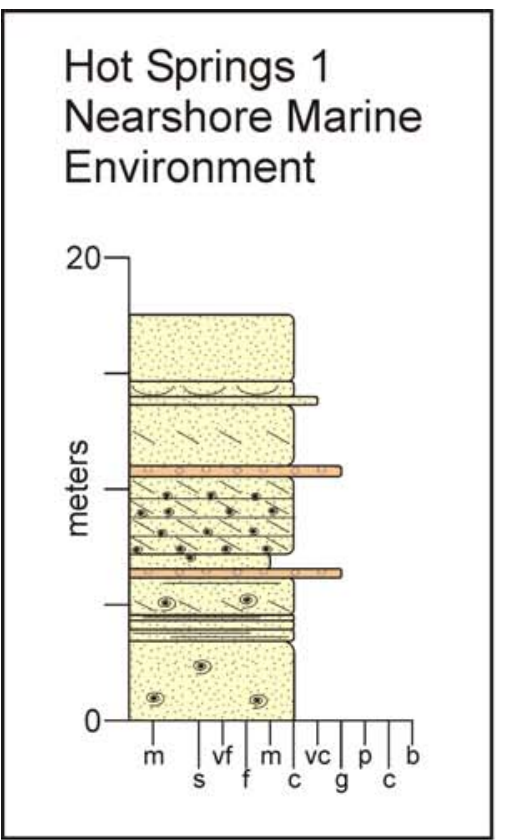

Figure 3.13. Hot Springs 1 measured section, Herendeen Formation.

Lithic intervals are shown for section. See figure 3.3A for key to measured section.

Figure 3.14. Harbor Point 1 measured section, unnamed Oligocene(?) strata. Lithic intervals are shown for section. See figure 3.3A for key to measured section.

\section{Harbor Point 1 \\ Marine shelf adjacent} to a volcanic arc

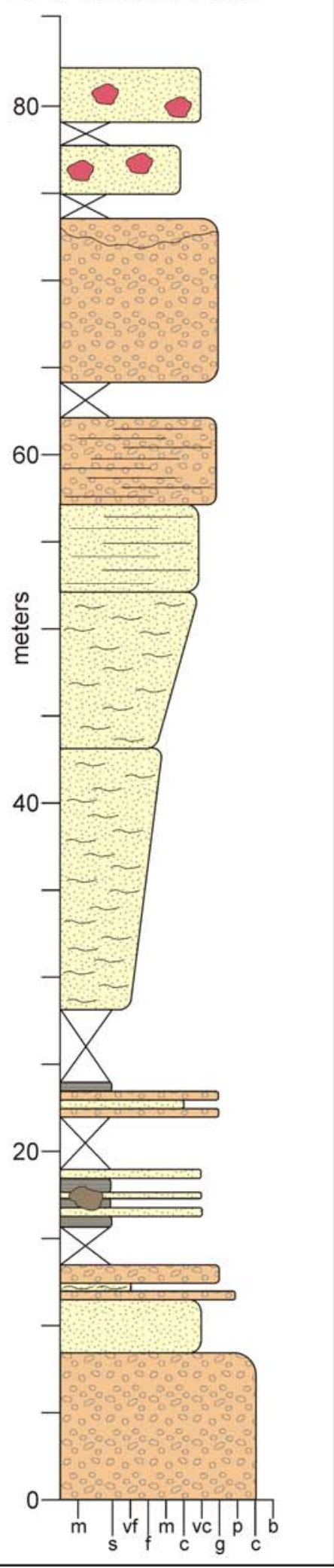




\section{Section IV. Preliminary Subsurface Interpretations of the \\ Bristol Bay/North Aleutian Basin and Alaska Peninsula}

\section{Introduction}

The Alaska Department of Natural Resources has established an ongoing effort first to make publicly available subsurface data more widely accessible, then to integrate these data with outcrop field studies to more fully interpret the resource potential of Alaskan basins. In the Bristol Bay region, this work has progressed in overlapping phases: (1) initial compilation and distribution of digital geologic and geophysical data and maps in a three-volume CD-ROM by the Division of Oil \& Gas (DOG, 2004), (2) joint outcrop studies by the Division of Geological \& Geophysical Surveys (DGGS), DOG, academia, and industry, and (3) interpretation studies of well and seismic data, including the integration of a coherent biostratigraphic dataset purchased for public release during July 2005. This preliminary report briefly describes the well data, seismic surveys, and biostratigraphic information now available to the public, followed by an overview of subsurface interpretations within DNR to date. These interpretations are focused mostly in the region of the October 2005 areawide lease sale and the adjacent Tertiary basin offshore (figs. 1.1 and 1.2).

\section{Public Domain Subsurface Data}

Well data. The initial DNR digital data compilation (DOG, 2004) included log curves for 27 wells (including sidetrack holes) on the Alaska Peninsula, offshore in Bristol Bay, and in neighboring portions of the Bering Sea. Digital logs are available for all 11 wells within the lease sale planning area. Additional scanned log images were released for a total of 47 wells, including standard wireline logs and mudlogs for nearly all, and dipmeter plots where available. Miscellaneous drilling reports, core and cuttings descriptions, poroperm data, geochemical data, etc., are also available, through the Alaska Oil \& Gas Conservation Commission (AOGCC), Bristol Bay Native Corporation (BBNC), and DGGS reports. The North Aleutian Shelf COST 1 well drilled offshore in 1983 is perhaps the best documented well with strong relevance to the state areawide lease sale, with drilling results summarized by MMS geologists and geophysicists in Turner (1988).

Seismic data. Seismic data included in the DOG digital compilation were converted to digital SEG-Y format from paper sections released through the Minerals Management Service (MMS)/National Geophysical Data Center (NGDC) (offshore) and BBNC (onshore). Most of the seismic coverage belongs to two offshore programs (fig. 4.1): 15 regional reconnaissance lines from survey USGS L5-76 covering parts of the Bristol Bay, Amak, and St. George basins, and 44 lines acquired under MMS seismic data permit 75-17 in a loose grid concentrated mainly in the southwestern Bristol Bay basin and Black Hills uplift. Typical line spacing in the MMS 75-17 grid is roughly 5 miles, but ranges from less than 2 to more than 30 miles. This coverage permits at least low-resolution mapping of an offshore area of approximately 15,000 square miles. Additional data have recently been released by MMS through NGDC, and selected surveys have been scanned and at least partially converted to digital SEG-Y format. For example, eight lines from MMS seismic data permit 75-09 are now available for free download from NGDC.

At present, onshore public digital seismic data coverage is limited to the ARD and ANM surveys in the lowlands northwest of Ugashik and Becharof Lakes, where a total of 23 lines tie the Ugashik 1, Becharof 1, and Great basins 1 and 2 wells and adjacent area (figs. 4.1 and 4.2). There are no seismic lines available to tie these surveys or any of the onshore wells in the planning area directly to the offshore data. Though the onshore seismic data are sparse and of variable quality, BBNC is re-inventorying its hardcopy seismic archive with the intention of releasing key additional lines if possible.

Biostratigraphic analysis. Many of the sedimentary units mapped in the onshore outcrop belt have strong lithologic similarities as a result of their volcanic-intrusive arc provenance and nonmarine to shallow marine depositional setting. Given the high degree of lateral facies variability expected in such units, a general lack of regional marker horizons, the paucity of onshore seismic control, and the masking of structural complications by surficial deposits of the coastal plain, it is essentially impossible to correlate confidently between many of the wells on the basis of wireline logs and cuttings lithology alone. For this reason, DOG has contracted with Micropaleo Consultants to conduct a comprehensive, integrated biostratigraphic analysis of 11 key wells, including all but one of the 11 wells in the areawide sale area, plus the NAS COST 1 well (fig. 4.2). Many age determinations from this new study were incorporated into subsurface interpretations discussed below, and final products are scheduled for delivery and public release during July 2005 (Mickey and others, 2005). 


\section{Basin Architecture}

Seismic interpretation horizons. Most of the seismic sequences defined in Turner (1988) at the NAS COST 1 well can be assigned to onshore formation equivalents on the basis of biostratigraphic ages, lithology, and petrophysical character. For this study, five Tertiary horizons have been interpreted at varying degrees of completeness across the MMS 75-17 and USGS L5-76 datasets, originating at the COST well. From oldest to youngest, these five horizons are considered to represent the upper Eocene unconformity corresponding to the top of the Paleocene (?) to Late Eocene Tolstoi Formation where it is preserved, the top of the Late Eocene to Late Oligocene Stepovak Formation, the top of Late Oligocene Unga equivalent strata, the top of the Miocene Bear Lake Formation, and the top of the Pliocene Milky River Formation (fig. 4.3). Though not penetrated in NAS COST 1, an inferred Top Mesozoic horizon has also been recognized and correlated across much of the offshore data. These horizons and stratigraphic units provide the framework for discussing the architecture of the Bristol Bay basin and its margins, with implications for prospectivity.

Preliminary time structure maps (fig. 4.4), together with observed thickness variations and relationships of interpreted horizons to faults and flexures, clearly demonstrate several key elements of the Bristol Bay basin below the North Aleutian Shelf, but leave many questions unanswered where the seismic data approach the state lands and waters of the areawide lease sale. This study has included fault interpretation in the process of correlating seismic horizons, but correlation of faults from line to line for mapping of fault traces has been limited so far, due to low data density and time constraints.

Controls on Tertiary basin development. At its simplest level, the Tertiary history of the Bristol Bay basin can be considered in three major phases: (1) extensional faulting (Walker and others, 2003) or transpressional folding (Worrall, 1991), here considered to be Paleocene(?) to middle or late Eocene age, prior to development of the regional late Eocene unconformity (the "red surface" of Worrall, 1991); (2) late Eocene to middle Miocene flexural subsidence; and (3) late Miocene to Holocene asymmetric subsidence, driven by sedimentary and volcanic loading of the southeastern basin margin (Walker and others, 2003), possibly facilitated by large-scale down-to-northwest normal faulting on the Alaska Peninsula. In terms of the stratigraphic units used in this study, these three phases correspond to (1) deposition of the northerly-derived nonmarine to shallow marine Tolstoi Formation, (2) deposition of the nonmarine to shallow marine strata of the Stepovak Formation, Unga equivalent, and Bear Lake Formation, all apparently derived from the Alaska Peninsula, and (3) strong northwestward progradation of the Milky River Formation into the asymmetric, underfilled basin.

Consistent with Walker and others' (2003) interpretation of a 180-km-long, north-south oriented deep crustal seismic and potential fields transect, the offshore basin is interpreted here as underlain at depth by an array of eastto east-northeast-trending fault-bounded horsts and grabens formed during the first phase. This view is partially at odds with that of Worrall (1991), who interpreted these early highs and lows as en-echelon anticlines and synclines, formed oblique to the system of dextral wrench faults on the basin's southern margin. Clearly, these structures developed at a time of regional wrench deformation along the Bering Sea transform margin during early Tertiary time, coeval with development of the Navarin and St. George pull-apart basins. Taken alone, the Bristol Bay seismic data do not clearly define the geometry and kinematic origin of the basin's deeper structural elements, but it is considered most likely here that these early structures are fault-bounded blocks, formed in a transtensional setting north of the Black Hills uplift, with components of both extension and dextral strike-slip deformation.

Whatever their exact origin, one of the deepest of these grabens was deliberately chosen as the site of the NAS COST 1 well (fig. 4.5, section A-A'), which bottomed at 17,155 ft measured depth in thick nonmarine clastic strata of Early and Middle Eocene age (Turner, 1988, Mickey and others, 2005) assigned herein to the Tolstoi Formation. Thus, NAS COST 1 itself provides no direct evidence whether the Mesozoic section underlying the Bristol Bay basin consists of regionally metamorphosed and intruded rocks akin to the Iliamna subterrane, or of sedimentary strata related to the Chignik subterrane (both defined by Wilson and others, 1999), potentially including oil-window maturity, source-prone Triassic, and Jurassic units. These are the source rocks that set up the petroleum system so evident in the Puale Bay-Wide Bay-Chignik Bay area on the Pacific side of the Alaska Peninsula. Seismic data in various parts of the basin show reflectivity below the inferred Top Mesozoic horizon that is consistent with, though not necessarily diagnostic of, the presence of Chignik subterrane units.

Southwestern Bristol Bay basin margin, Black Hills uplift, and northern Amak basin. The southwestern margin of the Bristol Bay basin is the Black Hills uplift, an east-west-trending high that separates the basin from the Amak basin to the south (figs. 4.4b and 4.5, section B-B'). Worrall (1991) and Walker and others (2003) recognize this 
feature as a major wrench uplift, developed at a compressional left-stepping relay between overlapping right-lateral strike-slip fault systems. Upper Jurassic Naknek Formation is exposed onshore in the Black Hills area, at the crest of the uplift near the Cathedral River 1 well, which drilled to 14,301 feet measured depth (MD) entirely in Jurassic sedimentary rocks with abundant oil and gas shows and TAI levels ranging from oil window to dry gas window maturity (Mickey and others, 2005). This is an extremely important finding in that it confirms the presence of the Chignik subterrane and its petroleum system in the Black Hills area, though the Triassic Kamishak Formation, a known source rock unit previously interpreted by Detterman (1990) to be penetrated at the bottom of Cathedral River 1, is not recognized by Mickey and others (2005).

The Top Mesozoic seismic horizon carried in this study is defined as the unconformity underlying the Tolstoi Formation on the down plunge projection of the Black Hills uplift, offshore and to the west of Cathedral River 1. Folded reflections near the crest of the uplift, most likely from Jurassic to Neocomian sedimentary units, are unconformably onlapped on its flanks by a wedge of more gently dipping Tolstoi Formation that pinches out near the crest of the high. Where the Tolstoi pinches out, the Mesozoic is locally capped by the upper Eocene unconformity or "red surface" (Worrall, 1991), which is in turn onlapped by subhorizontal reflections of the uppermost Stepovak Formation. These erosional and onlap relationships demonstrate that uplift of the Black Hills began prior to or during Paleocene to middle Eocene Tolstoi deposition, and that the block remained elevated through most of Oligocene Stepovak deposition. The Top Mesozoic horizon has been extended to the north and east, with decreasing confidence, across much of the available offshore seismic data in the Bristol Bay basin. Again, there is no direct evidence whether or how far the Mesozoic Chignik subterrane petroleum system at work in the Black Hills uplift extends beneath the Bristol Bay basin.

Faults separating the Black Hills uplift from the Bristol Bay basin are beautifully imaged on some offshore seismic lines (fig. 4.5, section B-B'), and either obscure or absent on others, where the basin margin instead appears as a zone of abrupt structural relief, thinned Tertiary stratigraphic units, and strong northerly dip (fig. 4.6). Efforts to correlate the major faults on the north side of the uplift are limited by the wide line spacing, and the fact that the uplift trends onshore, and the lines end several miles offshore. Nevertheless, it appears likely that the northern margin of the uplift is a composite of tandem or multiple fault strands. Areas with structural relief but no apparent fault offset may represent transfer zones, in which much of the strain is accommodated by flexures and/or lowdisplacement faults.

Onshore, the northern side of the Black Hills uplift is observed in the coastal plain as a steep gradient in the gravity data (DOG, 2005) and a subsurface belt of major structural relief between the Cathedral River 1 and Hoodoo Lake Unit 2 wells on the south, and the David River 1 and Hoodoo Lake Unit 1 wells on the north. Approximately 40 miles east of the outcrops of Jurassic Naknek Formation in the Black Hills, the next surficial expression of the uplifted margin is the east-west-trending, north-vergent thrust fault zone west of Herendeen Bay (Wilson and others, 1999). East of Herendeen Bay, this fault zone trends into an area of complex faulting and folding, including the northeast-plunging, extensively cross-faulted Staniukovich Mountain anticline, which hosts the gas seep and hot springs on the Herendeen Peninsula. Additional field work will be required to establish the number, structural style, and relative ages of deformational episodes in this area, their relationship to development of the Black Hills uplift, and the likelihood that similar or related folds and fault blocks are present as potential hydrocarbon traps in the subsurface of the adjacent coastal plain.

The southwestern portion of the areawide sale extends beyond the southern flank of the Black Hills uplift into the northern edge of the Amak basin. Here, a series of steep faults interpreted as mainly dextral strike-slip (Worrall, 1991) are clearly evident in the seismic data (fig. 4.5, section B-B'). These faults separate blocks with marked thickening to the south, but the listric geometry and rotated reflectors characteristic of normal growth faulting are notably absent. The thickness discrepancy across these steep faults is interpreted here as wrench-related syntectonic depositional growth of all the Tertiary units, demonstrating Amak basin subsidence throughout Eocene to Pliocene time. Only a handful of the available seismic lines extend into the Amak basin, but they suggest high potential for fault- and unconformity-trapping geometries in reservoir-prone middle to upper Tertiary units on the southern side of the Black Hills uplift.

Southeastern Bristol Bay basin margin, Alaska Peninsula lowlands. There is little or no seismic data available to image the actual southeastern margin of the basin directly underlying the portion of the state areawide sale between the Port Moller and Egegik River areas. Particularly elucidating would be a clear seismic image of the onshore subsurface crossing the edge of the basin through the Sandy River 1 well. According to BBNC records, in 1974 Phillips Petroleum acquired line 4C, a three-segment seismic traverse across the Alaska Peninsula through Sandy River 1, but after considerable searching of both BBNC and ConocoPhillips archives, the actual data for this and the other 18 lines from the $1974 \mathrm{C}$ survey have yet to be located in either hardcopy or digital form.. 
Seismic data offshore from Sandy River 1 show gentle, landward regional dip in Oligocene and younger units at least as far as the end of the lines a few miles from the shoreline. The well encountered abundant live oil shows below $10,000 \mathrm{ft}$, as well as a profound change in dip from mostly $<10$ degrees southerly dip between 11,000 and $12,200 \mathrm{ft}$ (consistent with the regional dip seen in the offshore seismic data) to northwesterly dips mostly in the 4050 degree range below about 12,280 ft. Cores at and near the bottom of the well (13,068 ft TD, total depth) are firmly dated as Late Eocene age (Mickey and others, 2005), despite McLean's (1977) suggestion on lithologic grounds that the well may have bottomed in Upper Cretaceous Chignik Formation. The simplest explanation of the dip change may be that the shallower part of the well penetrates generally subhorizontal to gently southeast dipping strata like those seen offshore, then crosses a down-to-northwest normal fault, with the steeper northwesterly dips resulting either from normal drag of beds near the fault, or from crossing into older and previously deformed strata in the footwall. Alternatively, the well may not have crossed a fault, but rather a significant angular unconformity within the Eocene section, underlain by more steeply dipping strata.

Southwest of the southern shore of Becharof Lake, there is no outcrop evidence for the up-to-northwest Bruin Bay reverse fault that forms the boundary between the metamorphosed Iliamna subterrane to the northwest and the sedimentary Chignik subterrane to the southeast. Normal faults of Miocene or younger (post-Bear Lake Formation) age mapped over a short distance in outcrop by Wilson and others (1999) near Ugashik Lakes coincide closely with a much longer set of strong, slightly arcuate aeromagnetic anomalies (Case and others, 1988; DOG, 2005). These concave-to-northwest lineaments begin essentially where the surface trace of the Bruin Bay fault ends and continue approximately 115 miles to the southwest. These magnetic anomalies have been conjectured to represent the possible extension of the Bruin Bay fault itself (Case and others, 1988), but based on their arcuate trace and coincidence with the mapped normal faults, it is considered more likely here that they represent a belt of younger, down-to-northwest normal faults with extensional displacements as young as late Tertiary age. If so, they may offset the older Bruin Bay fault or exploit a portion of it as a zone of preexisting weakness.

Regardless of any speculative relationship to the Bruin Bay fault, this speculative zone of mostly cryptic normal faults, which appear small in outcrop (Wilson and others, 1999), could represent the major structural control on subsidence at the southeastern margin of the Bristol Bay basin, particularly during the strongly asymmetric late Miocene and younger phase. Note that the down-to-northwest normal fault hypothesized from dipmeter data in Sandy River 1 is consistent with faults of this orientation and sense of displacement. Additionally, a major fault with apparent dip to the northwest is interpreted on line ARD-8, located in the lowlands west of Lower Ugashik Lake. This fault is west of the main magnetic lineaments described above, it has no known outcrop expression, and its sense of throw is unknown, but it is possible it could be one strand of a synthetic normal fault array bounding the Bristol Bay basin on its southeastern margin. The very limited seismic data available in that area show a number of untested, fault-related structural leads with Tertiary reservoir potential that may warrant acquisition of additional seismic data.

Northern Bristol Bay basin margin. North of the array of east- to east-northeast-trending horsts and grabens that define the deep Bristol Bay basin, the northern and northwestern margin of the basin appears on the northern end of most of the MMS and USGS seismic lines as a gently southeast-dipping flexural ramp rising and flattening gradually toward the northwest. The deep crustal seismic and potential fields transect modeled by Walker and others (2003) shows that this gradual northward thinning of the basin continues well to the north. Tolstoi Formation strata appear to be preserved very locally north of the grabens. Where it is absent, the upper Eocene "red" unconformity lies directly on Mesozoic units, which Walker and others (2003) believe consists entirely by Peninsular terrane crust, though they draw no distinction between rocks of the Iliamna and Chignik subterranes. The bathymetric data along their transect is approximated by a fourth-order polynomial, whose shape suggests flexural subsidence continues today (Walker and others, 2003).

\section{Subsurface Stratigraphic Observations}

Exploration significance of the Bear Lake-Milky River unconformity. The Tertiary stratigraphic succession at NAS COST 1 has been divided into five major unconformity- or disconformity-bounded seismic sequences (Turner, 1988), but other than the angular unconformities described above on the Black Hills uplift, seismic evidence for unconformities within the Tertiary succession is mostly very subtle. Offshore to the northeast of the Black Hills area, the clearest seismically imaged unconformity is at the contact between the Miocene Bear Lake Formation and the overlying Pliocene Milky River Formation. The reason for this erosion is not entirely clear, particularly since it appears to have been followed immediately by the major subsidence that generated the large amount of 
accommodation filled by the Milky River clinoforms. It may relate to the Late Miocene to Early Pliocene pluton emplacement throughout the arc noted by Wilson and others (1999).

Offshore, this surface shows truncation of underlying reflectors with angular discordance of a few degrees at most. This is in marked contrast to the appearance of the Top Bear Lake unconformity in spectacular Sandy Ridge area outcrops, where nonmarine units are intensely deformed with steep dips and dismembered isoclinal folds. Seismic lines flattened on the unconformity offshore reveal varying dip directions of the underlying reflections in different parts of the basin (fig. 4.7). On line MMS 75-17-46, southwest of NAS COST 1 offshore from the Cathedral River-David River area, underlying strata tilt northwestward (away from the Black Hills Uplift) relative to the unconformity datum. Flattening line MMS 75-17-18, northeast of the COST well offshore of Port Moller, underlying Bear Lake Formation reflections appear to dip mainly southeast, with truncation most evident on the northwest margin of the basin.

Lacking seismic data to tie those offshore lines to the onshore unconformity at Sandy Ridge, the temporal relationship between the rocks below the slightly discordant contact offshore and the profoundly angular onshore contact remains enigmatic. Though in both areas the surface marks the boundary between Miocene units below and Pliocene strata above, the uppermost Bear Lake Formation strata preserved below the unconformity are not necessarily time equivalents. It is possible that the intensely deformed unit at Sandy Ridge may correlate to an interval well below the top of the Miocene section offshore. If so, a low-coherence, low-reflectivity seismic facies observed offshore within the Bear Lake Formation could be the offshore extension of the chaotically deformed interval. Whatever it's extent and correlation into the subsurface, the chaotic structure and dismemberment of Bear Lake beds at Sandy Ridge is probably the product of a near surface deformation process such as seismically-induced liquefaction, gravitationally driven displacement, or some form of mass wasting rather than compressional folding and thrusting. Very similar structures in analogous mixed volcanic and epiclastic sedimentary strata of the lower Absaroka Volcanic Supergroup of Wyoming are attributed to such mechanisms (Decker, 1990).

Renewed deposition following this erosional event filled much of the Pliocene basin with a wedge of northwest-prograding clinoforms belonging to the Milky River Formation. The finer-grained, distal toes of these clinoforms downlap onto the gently discordant unconformity offshore. If the shelfal mudstones present in the lower Milky River Formation at NAS COST 1 are widely distributed and behave as a seal at this downlap surface, hydrocarbons could be reservoired in the upper Bear Lake sandstones in truncation traps beneath the unconformity.

Biostratigraphic basis for revising correlations. As with every other interpretive data type, biostratigraphic data must be viewed with an eye toward their inherent uncertainties. In fact, a comparison of biostratigraphic interpretations prepared previously by different companies for the same wells (available in BBNC well files) shows that, in many cases, different biostratigraphers have arrived at sharply different opinions over the years. It is maintained here that the new biostratigraphic results of Mickey and others (2005) should represent a much more reliable and consistent biostratigraphic zonation of the basin, due to both regional expertise and the project's approach; one group of interpreters has analyzed and integrated multiple microfossil types from all 11 of the study wells, arrived at a standardized zonation, and correlated these age units regionally on well log cross sections. Not surprisingly, the new results by Mickey and others (2005) disagree with many of the formation picks interpreted and reinterpreted by previous workers (Brockway and others, 1975; McLean, 1977; Detterman, 1990), who did their best to distinguish the various arc-derived, nonmarine to shallow marine formations from one another using lithologic descriptions using mudlogs of highly variable quality, ditch samples, and cores. The inherent lithologic similarity of these formations naturally leads to considerable differences of opinion, particularly when examined using these types of data from widely-spaced wells, in most cases drilled on the coastal plain, devoid of outcrop context. The following are some examples in which Mickey and others (2005) provide a biostratigraphic basis for revising previous formation picks.

As stated previously, one key finding of the biostratigraphic analyses of Mickey and others (2005) is that there is firm biostratigraphic evidence from multiple cores to refute the previous lithology-based suggestion by McLean (1977) that Sandy River 1 penetrated Upper Cretaceous Chignik Formation. Similarly, the previous lithology-based interpretation by Detterman (1990) that David River 1/1A and Hoodoo Lake Unit 2 both penetrated thrust faults that place Mesozoic units over Tertiary strata is not supported by the biostratigraphic data, though extra samples were collected and processed from cuttings in both wells to investigate that assertion. Both wells are confirmed by Mickey and others (2005) as having penetrated Hauterivian and older units, but despite a deliberate search, neither well yielded any biostratigraphic evidence of passing back into Tertiary formations. It is impossible to build a strong case on the lack of evidence, particularly when certain facies can be expected to be barren of diagnostic fossils. Nevertheless, the conflicting results noted above are taken as a caution not to over-interpret any one type of data, particularly lithologic characteristics, in correlating formations in the Alaska Peninsula-Bristol Bay area. 
A number of credible correlations can be drawn on the basis of well log signatures among the relatively closely clustered Great basins 1, Great basins 2, and Becharof 1 wells, though it is not evident from the logs alone which formations these correlations pertain to. Some of the shallow log correlation surfaces can be extended to Ugashik 1 and Port Heiden Unit 1, an additional distance of more than 80 miles. In general, the log-correlated surfaces closely parallel the correlations independently developed through the biostratigraphic analysis by Mickey and others (2005), but the ages they assign are significantly different than any of the previous lithology-based formation picks at the Great basins 1 (Detterman,1990; McLean, 1977; Brockway and others, 1975).

Detterman (1990) considered the bedrock stratigraphy at Great basins 1 to consist of Jurassic batholith at TD, intruded into contact-metamorphosed Naknek Formation conglomerate, followed by a Tertiary succession of the Tolstoi, Bear Lake, and Milky River formations, capped by $350 \mathrm{ft}$ of glacial drift. He provided no explanation for the absence of Stepovak Formation, which Brockway and others (1975) and McLean (1977) had previously interpreted in place of the section he assigned to the Tolstoi. The biostratigraphically controlled interpretation of Mickey and others' (2005) lumps the plutonic rocks at TD together with the (barren) metamorphosed conglomerates, relegating both simply to the basement. Unconformably overlying this basement, their Tertiary stratigraphy begins with an undifferentiated Oligocene section (either Stepovak or Unga equivalent) less than $200 \mathrm{ft}$ thick. This is overlain in turn by more than 6,600 ft of Miocene (Bear Lake) section, 2,350 ft of Pliocene (Milky River) section, and approximately 1,300 ft of Quaternary sediments.

Correlating southwest from the Great Basins area toward Port Heiden, Mickey and others (2005) interpret two Miocene diversity and abundance horizons observed in surrounding wells as missing due to local uplift and prePliocene erosion at Ugashik 1, which penetrated a thick volcanic section interpreted as Oligocene Meshik Formation from 3,980 ft MD to 9,476 ft MD total depth. The western end of seismic line ARD-11 shows a major structural high drilled by Ugashik 1 flanked by dipping reflections, consistent in many respects with Mickey and others' (2005) interpretation, though the erosional truncation they depict at the pre-Pliocene unconformity is only subtly expressed in the seismic data (fig. 4.8).

\section{Subsurface Hydrocarbon Indications}

Oil and gas shows. Many of the wells in and near the region of the areawide lease sale offering have shows of oil and gas, as summarized previously by Hite (2004). None have flowed oil on test, but some gas tests have flowed at potentially economic rates. The numerous oil and gas seeps in the region are surface phenomena, and are discussed elsewhere in more detail. Suffice it to say in this context that all the known oil seepages on the Alaska Peninsula occur in or near outcrop of the Chignik subterrane. Those that have been typed geochemically originate from either the Upper Triassic Kamishak Formation or mid-Jurassic Kialagvik Formations, time equivalents of the Upper Triassic Shublik Formation, the source of much of the North Slope oil and the Tuxedni Group, which sources most oils in Cook Inlet.

Modern geochemical typing via extraction, carbon isotopes, and biomarker analyses is planned for oil shows in a number of wells, but this work is not yet underway. A key question is whether Mesozoic-source oils account for any of the shows in Tertiary reservoirs. If so, what does it reveal about the distribution of potential Chignik subterrane source rocks beneath the Tertiary Bristol Bay basin, or about probable migration routes between Mesozoic and Tertiary units? Though it has yet to be demonstrated chemically, it is all but certain that the abundant oil and gas shows throughout the Jurassic section on the crest of the Black Hills uplift at Cathedral River 1 come from Mesozoic source rocks. Less clear is the origin of the many oil and gas shows in Eocene Tolstoi sandstones in David River 1 and Hoodoo Lakes Unit 2, both of which lie on or near the north flank of the Black Hills uplift, and themselves penetrated Neocomian units of the Chignik subterrane at TD.

Among the remaining wells with oil shows in Tertiary units, shows in the lower Stepovak Formation (and possibly Tolstoi Formation) at Sandy River 1 stand out, both in abundance and show quality. All four cores either bled oil and gas or showed strong staining, spanning an interval of more than 1,300 $\mathrm{ft}$. The major dip change described earlier occurs in this interval of strong shows, and whether it is interpreted as a fault or an unconformity, either would be a likely migration route and/or a component of the trap for a possible oil accumulation at or near the well.

Further north, both Painter Creek 1 and Becharof 1 encountered fair to good oil and gas shows in coal-bearing Tertiary units, whereas Great basins 1 and 2 say moderate gas shows but only trace oil shows associated with coaly beds, and Ugashik 1 saw only coal-associated gas shows with no oil indications at all. Much of the gas associated with coal units is probably biogenic, but where coals and carbonaceous shales are accompanied by heavier gases (C3-C5), oil stains, sample fluorescence, and fluorescent cuts, a component associated thermogenic gas is considered likely. 
A surprising number of coals, carbonaceous mudstones, and other nonmarine shales from the Tertiary formations yield oil shows. Kerogen typing, such as at NAS COST 1 (Turner, 1988) suggests that in parts of these nonmarine units, liptinitic-amorphous kerogens account for well over 20 percent of the organic matter. One interval from approximately 16,000-16,600 ft MD in the Tolstoi Formation at NAS COST 1 contains lipid-rich shales in which the organic is at least 40 percent to more than 50 percent amorphous kerogen. Additionally, numerous Tolstoi Formation samples between 11,000 ft and 15,000 ft yield hydrogen indices in the 300-400 mg/g range, suggesting they might be capable of generating and expelling some light hydrocarbon liquids.

Possible seismic hydrocarbon indications. So-called direct hydrocarbon indicators (DHI's) based on seismic data are the subject of a vast and complex field of advanced interpretation. Some seismic anomalies interpreted as DHI's are highly misleading, and it is unclear whether the MMS 75-17 and USGS L5-76 datasets can be expected to yield trustworthy hydrocarbon indications. In any case, this study does not recognize the widespread occurrence of seismic anomalies suggestive of hydrocarbon accumulations. However, several candidate gas chimneys and one candidate flat spot (possible hydrocarbon fluid contact) are noted in a geological setting ideal for generation, migration focusing, and seismic imaging of hydrocarbons: the crest of the Black Hills uplift, where little-compacted Stepovak Formation, Unga equivalent, and Bear Lake Formation sandstones overlie high amplitude, Mesozoic strata at probable oil to gas window maturity (based on data from Cathedral River 1), truncated below the upper Eocene "red" unconformity. These seismic anomalies compare closely to gas chimneys from a North Sea seismic dataset (http://www.dgb-group.com, 2005) in terms of scale, reflection shape, and overall form (fig. 4.9).

\section{Recommendations for Future Work}

Clearly, the dataset and preliminary interpretations described here only begin to "scratch the subsurface" of what is required for a detailed understanding of oil and gas potential in the Bristol Bay basin. Additional effort should be devoted to interpreting the publicly available subsurface data, and to complementing it with additional data, both from outcrop and the subsurface. Ultimately, exploration of the lowlands on the northwest side of the Alaska Peninsula will require acquisition of carefully gathered modern seismic data to develop drillable prospects below surficial cover. Until then, any additional seismic data that can be released to the public should be pursued. Structural and stratigraphic field work should attempt to test the various hypotheses discussed above, particularly regarding the southeastern margin of the Tertiary basin beneath the coastal lowlands, as well as the nature and location of the boundary between the underlying Mesozoic subterranes.

Additional biostratigraphic work would be valuable to control correlations between outcrop sections and the wells. To the extent that the new biostratigraphic zonation of the basin provides more robust correlations of potential reservoir units, it would be valuable to integrate these new picks in pursuing reservoir quality and thickness assessments based on petrophysical, petrographic, and core poroperm data from both wells and outcrops.

Modern geochemical typing of oil shows can yield powerful insights into the workings of multiple-source petroleum systems, and the Bristol Bay basin is no exception. Additional geological and geochemical data on the stratigraphic and geographic distribution of potential nonmarine source rock facies would be very valuable, and should be accompanied by additional thermal maturity data, RockEval pyrolysis, total organic carbon analyses, kerogen typing, and possibly kerogen transformation kinetics. These data types are among the basic inputs for basin modeling to predict the quantities, types, and general distribution of thermogenic hydrocarbons in the basin. 


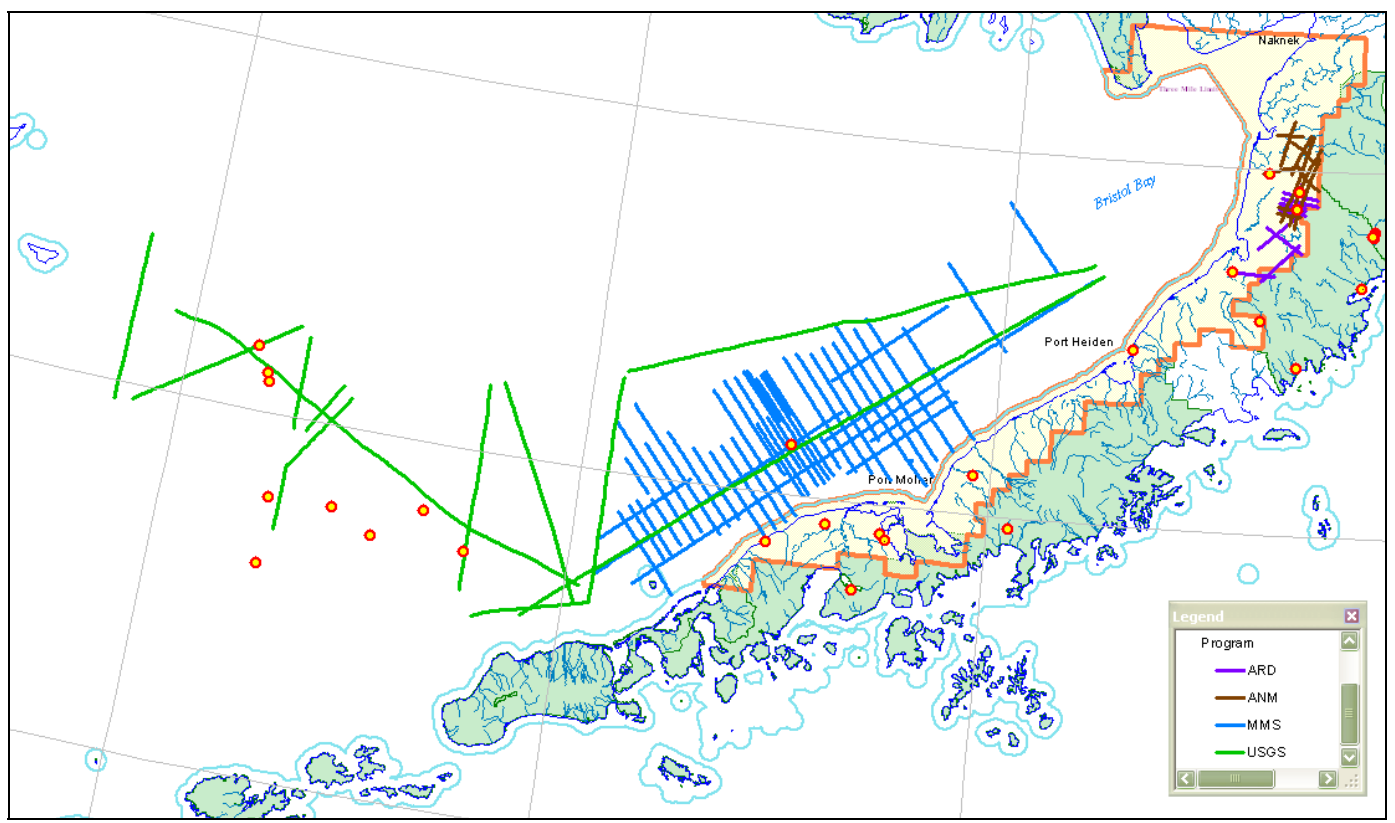

Figure 4.1. Publicly available seismic datasets used in this study, converted to SEG-Y format by DOG as one component of digital data compilation and release (DOG, 2004).

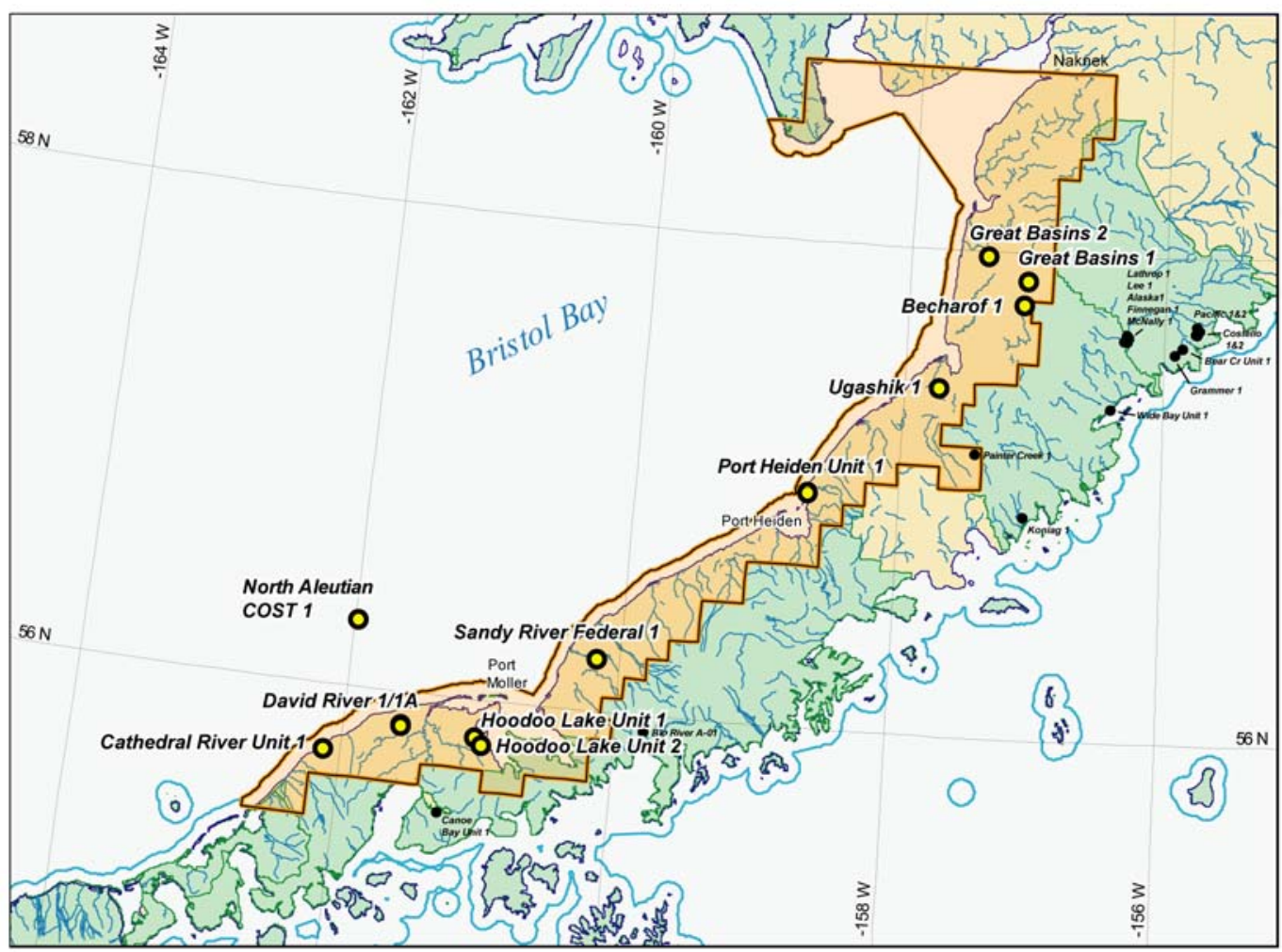

Figure 4.2. Location map showing 11 wells (yellow and black dots with large labels) included in Micropaleo Consultants' biostratigraphy analysis (Mickey and others, 2005) purchased by DOG, scheduled for public release in July 2005. 


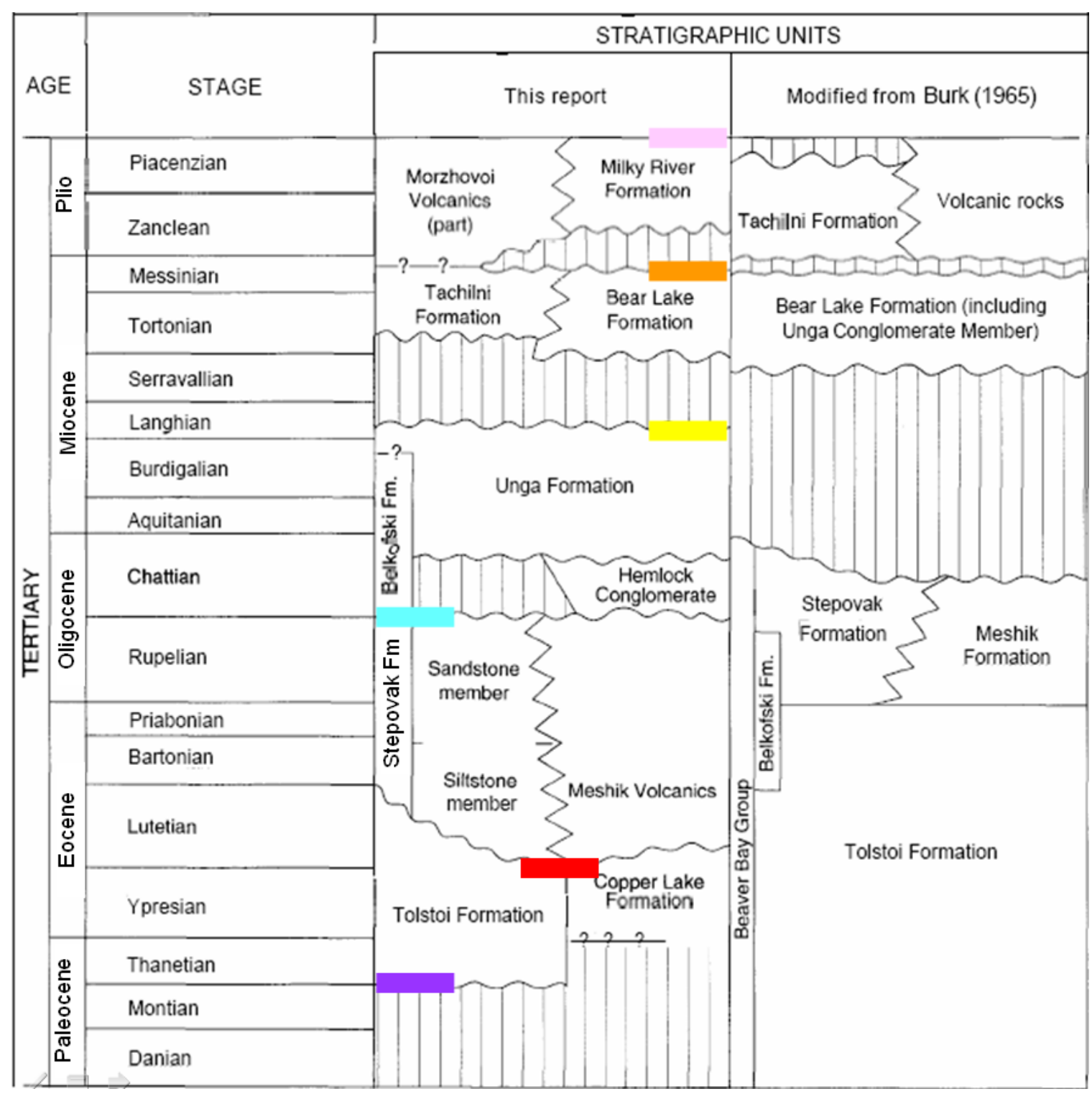

Figure 4.3. Stratigraphic column of Tertiary units, Alaska Peninsula, showing color-coded seismic horizons interpreted for this study: Inferred Top Mesozoic (purple), upper Eocene unconformity or "red surface" of Worrall (1991), corresponding to the Top Tolstoi Formation where it is preserved (red), Top Stepovak Formation (light blue), Top Unga equivalent (yellow), Top Bear Lake Formation (orange), and Top Milky River Formation (rose). 


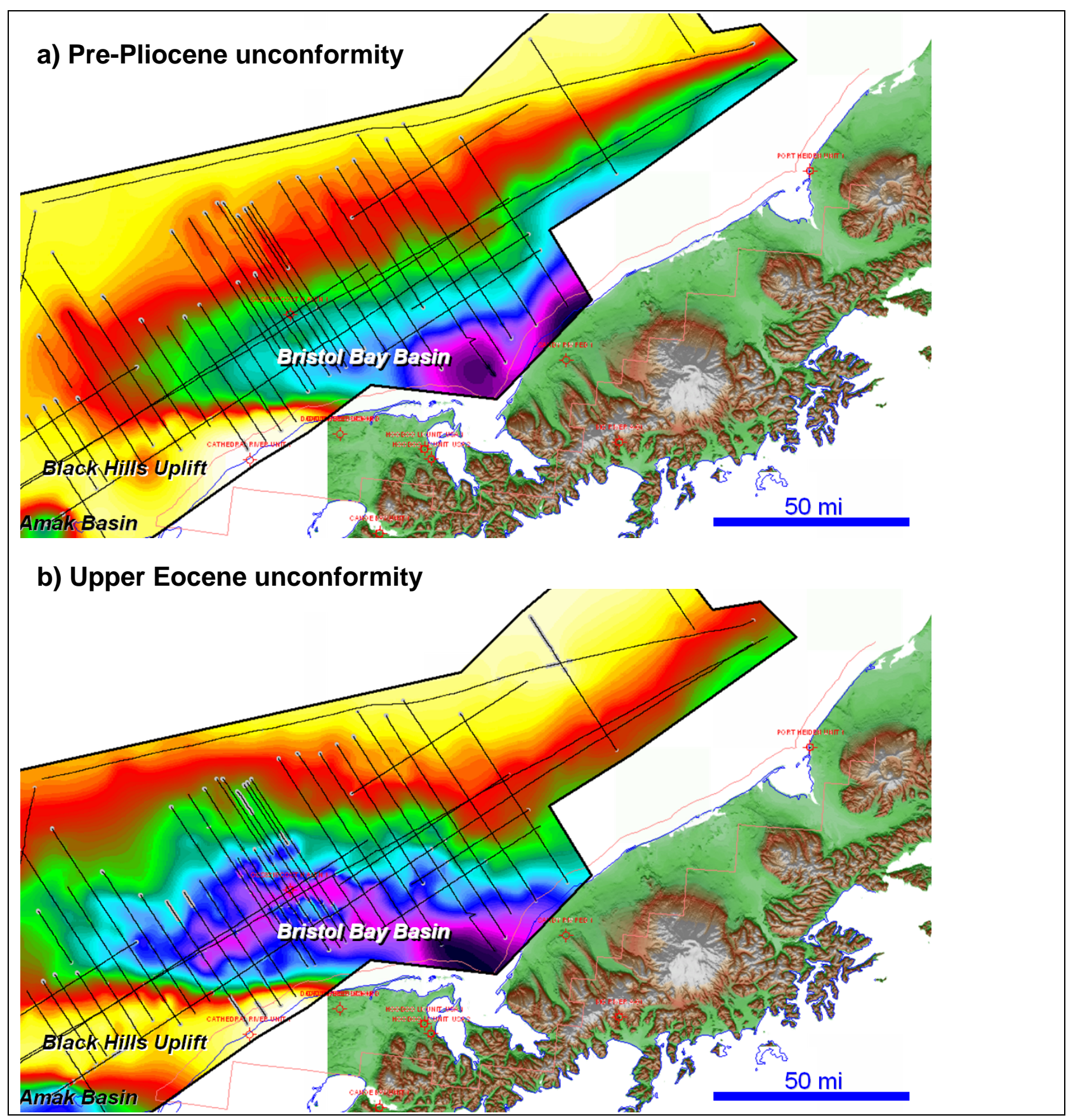

Figure 4.4. Preliminary two-way time structure maps of the Bristol Bay offshore area based on interpretation of publicly available offshore seismic datasets MMS 75-17 and USGS L5-76 for this study. Warm colors are structurally high, cool colors are deep. (a) Pre-Pliocene unconformity (Top Bear Lake Formation); time contours range from approximately 0.1 to $1.0 \mathrm{sec}$. (b) Upper Eocene unconformity ("red surface" of Worrall, 1991) overlying the Tolstoi Formation where it is preserved; time contours range from approximately 0.5 to more than $2.6 \mathrm{sec}$. Faults were included in horizon interpretations, but have not been correlated from line to line; these grids thus smooth across fault discontinuities. The deeper Eocene surface suggests the reast-west early structural grain of the deep Bristol Bay basin; the shallower pre-Pliocene hints toward the later asymmetric subsidence phase, with regional southeast tilting toward the onshore area, at least as far as the edge of the data. Digital elevation image for part of onshore area is adapted from BBNC figures in Hite (2004). 

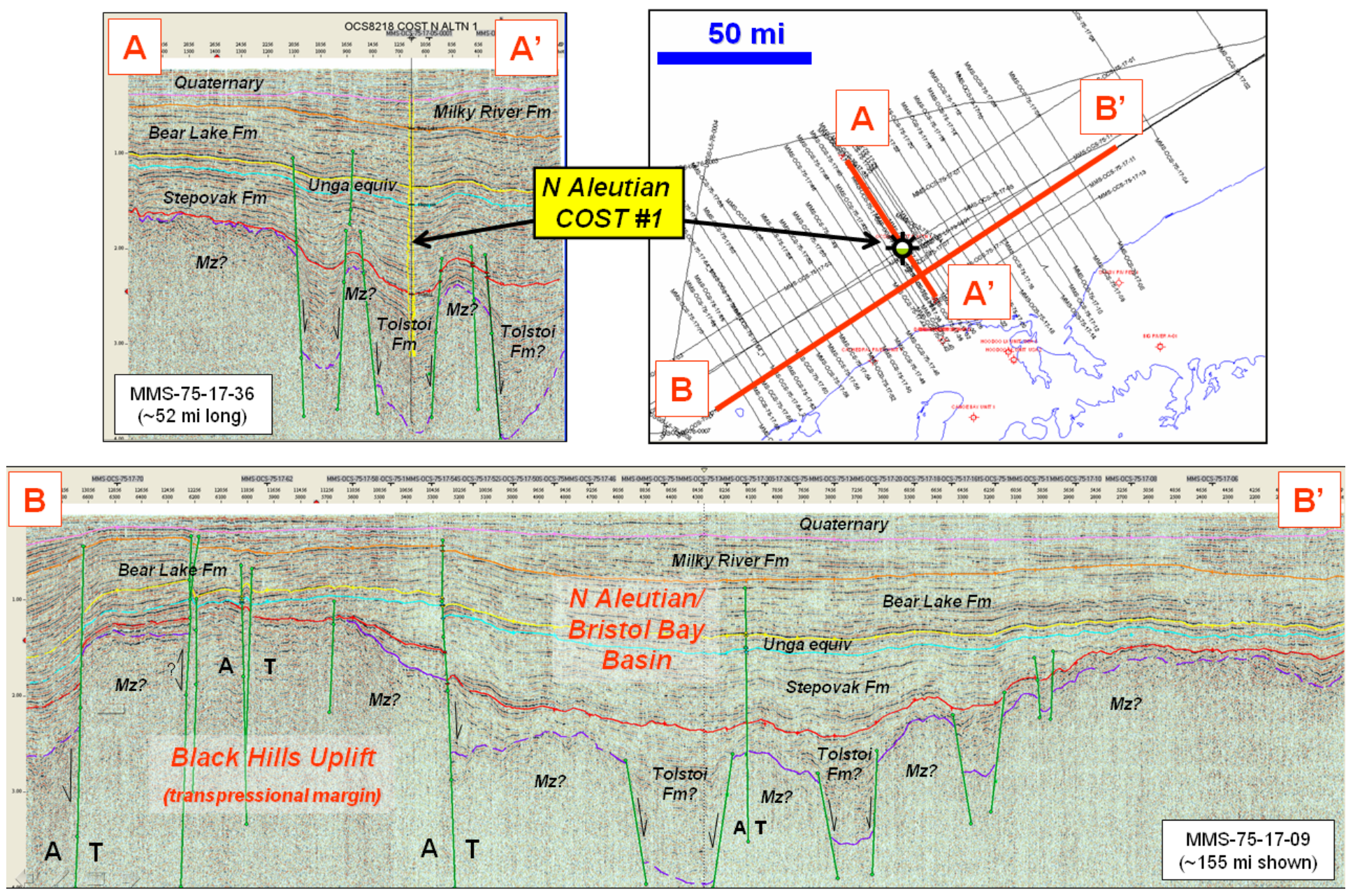

Figure 4.5. Representative seismic lines through the Bristol Bay basin. Section A-A' trends northwest-southeast through the North Aleutian Shelf COST 1 well, interpreted here to lie in one of several deep grabens formed during initial basin extension coeval with Tolstoi Formation deposition during Paleocene(?) to late Eocene time. Section B-B' trends southwest-northeast, from the edge of the Amak Basin (at left, not labeled), across the Black Hills transpressional uplift, and beyond the axis of the deep Bristol Bay basin to the area north of Sandy River 1. Both lines are oblique to most faults. Nearly vertical fault near center of basin shows minor vertical offset from Mesozoic through Miocene time, and suggests strike slip faulting well north of the Black Hills margin. 

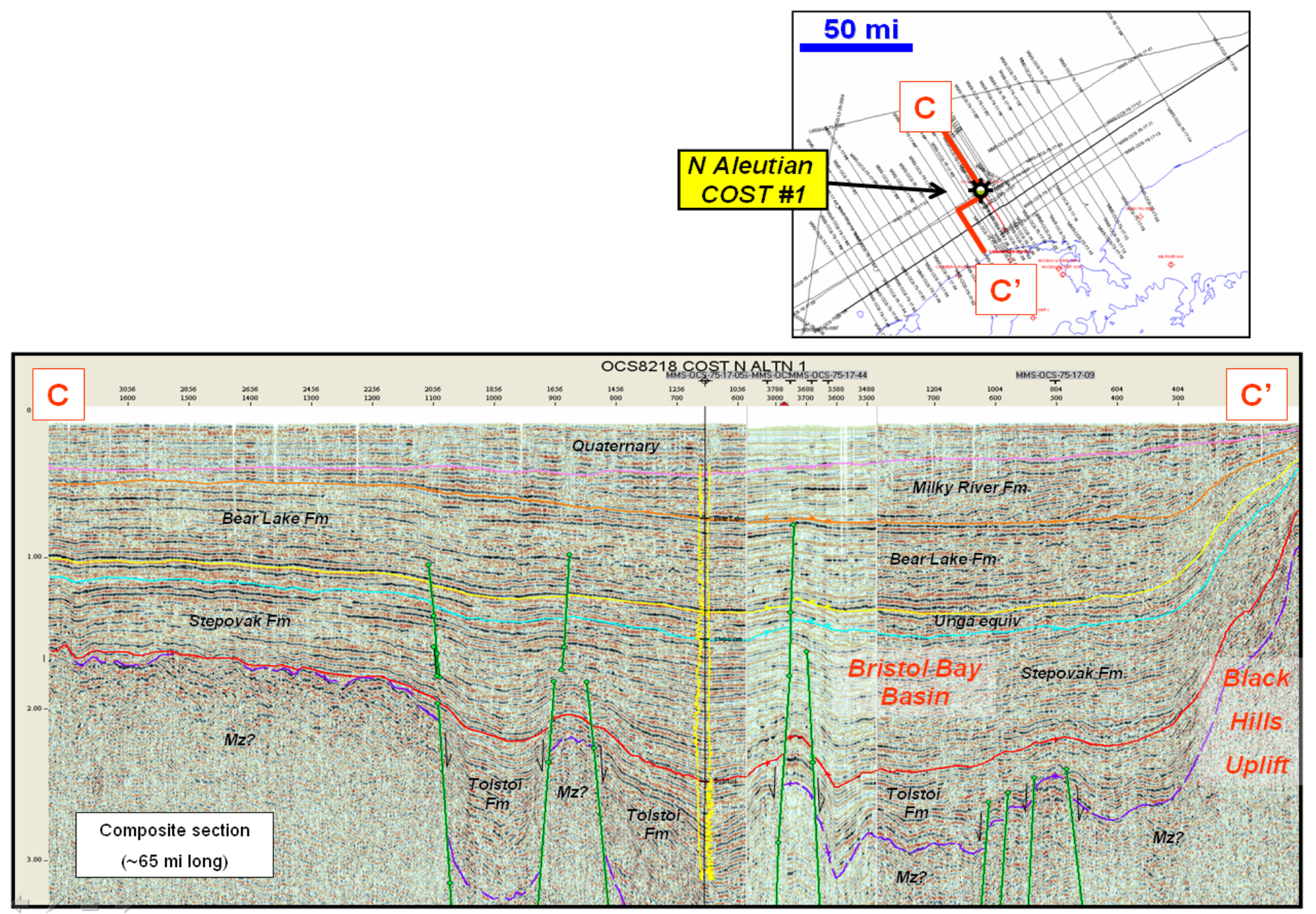

Figure 4.6. Composite seismic traverse C-C' trending generally southward through NAS COST 1 toward Black Hills margin between Cathedral River 1 and David River 1/1A. The uplift margin shows major structural relief on Mesozoic through Miocene strata, but without visible faulting, at least in the offshore data. Much of the transpressional uplift is accommodated in this area by flexure and/or distributed throw on poorly imaged faults. 

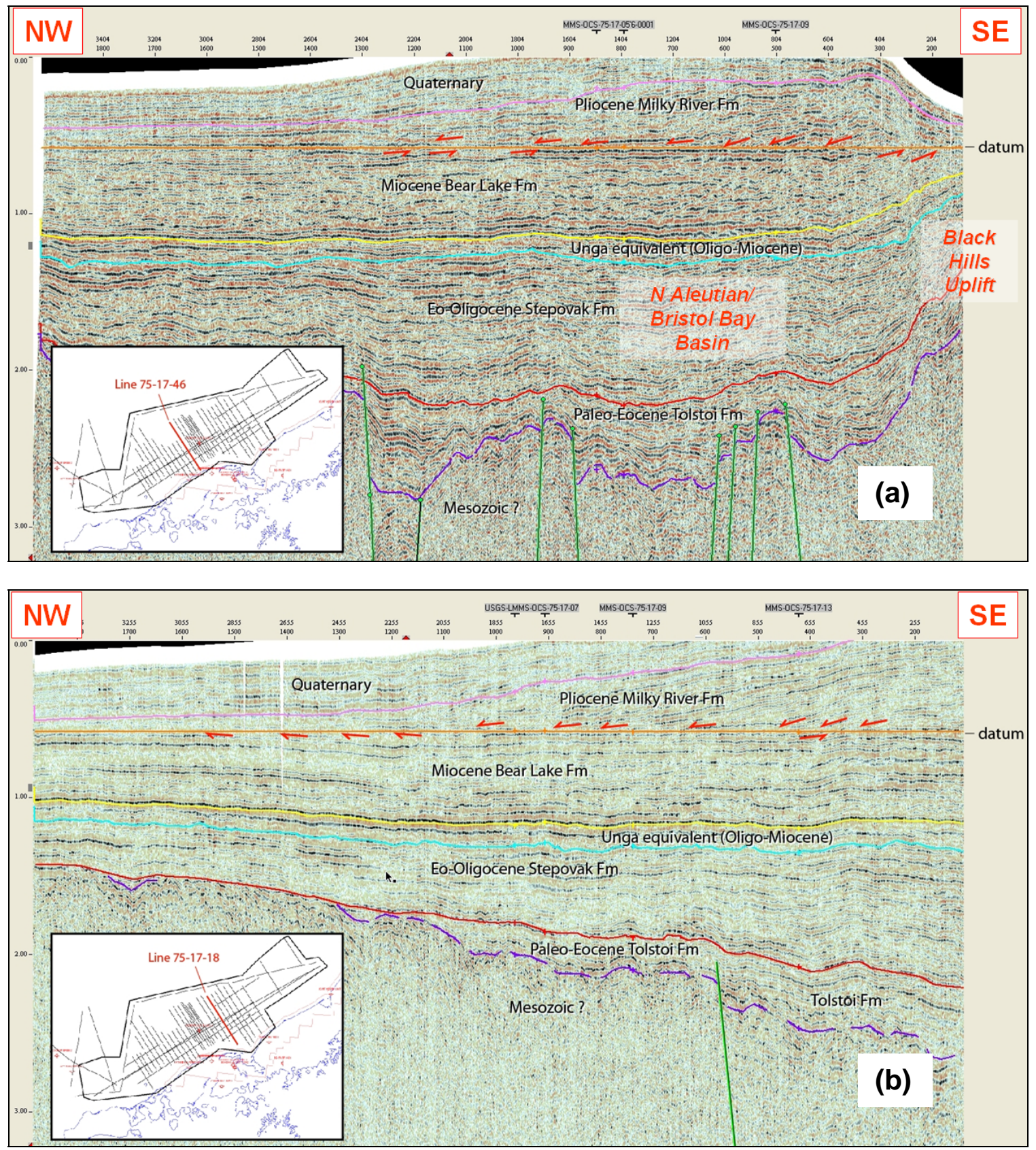

Figure 4.7. Flattened seismic lines showing truncation of underlying Bear Lake Formation reflections at pre-Pliocene unconformity. (a) Line MMS 75-17-46, located southwest of NAS COST 1, offshore from David River-Cathedral River area. (b) Line MMS 75-17-18, located northeast of NAS COST 1, offshore from Port Moller area. Note downlapping clinoforms of northwestwardprograding Milky River Formation. 


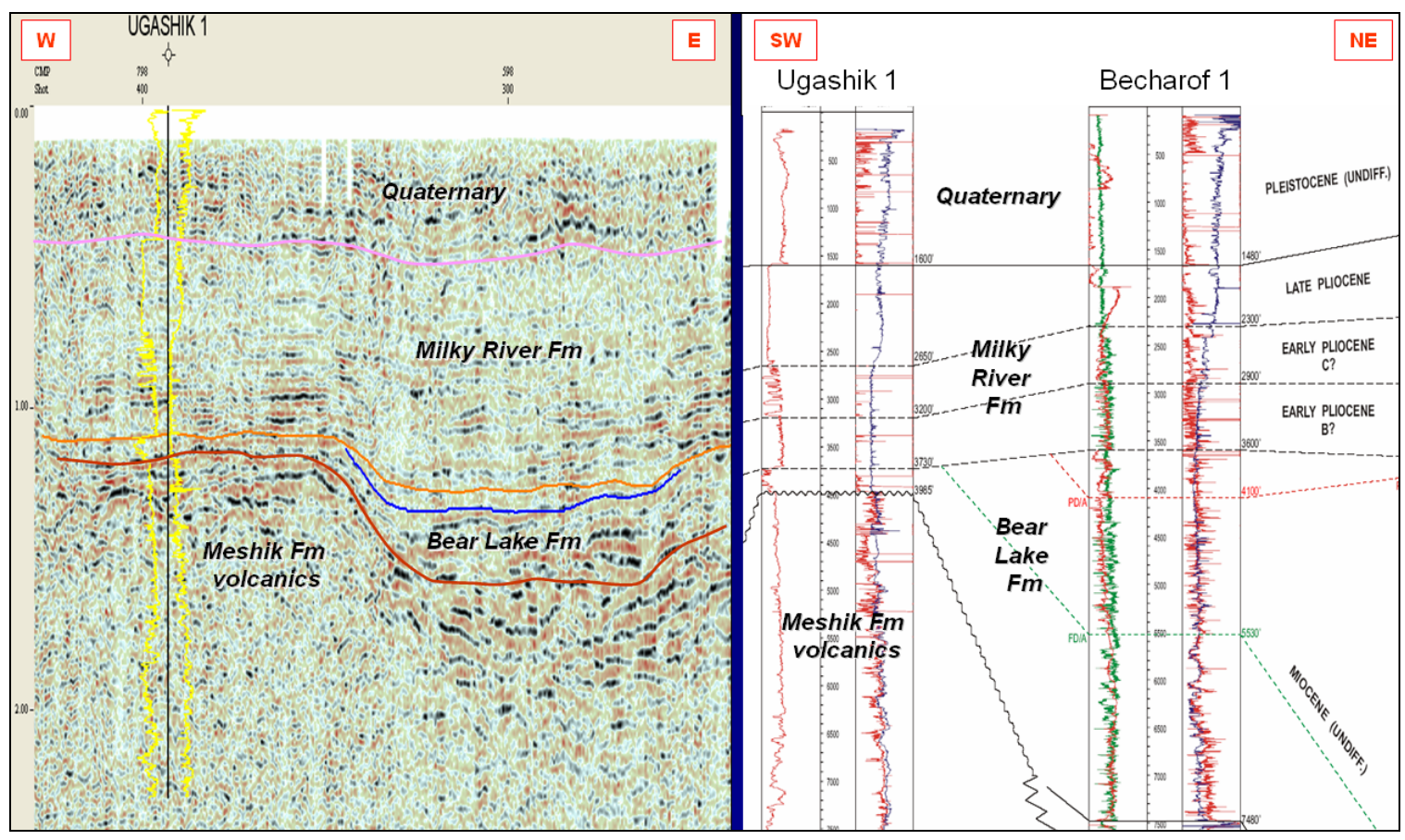

Figure 4.8. West end of line ARD-11 and excerpt of Mickey and others (2005) biostratigraphic correlation between Ugashik 1 and Becharof 1. Note that the two views are at different scales, and trend in different directions away from Ugashik 1, but the seismic data suggest truncation of Bear Lake strata (e.g., blue horizon) by pre-Pliocene unconformity on the flanks of the Ugashik high as depicted in the biostratigraphic correlation section.

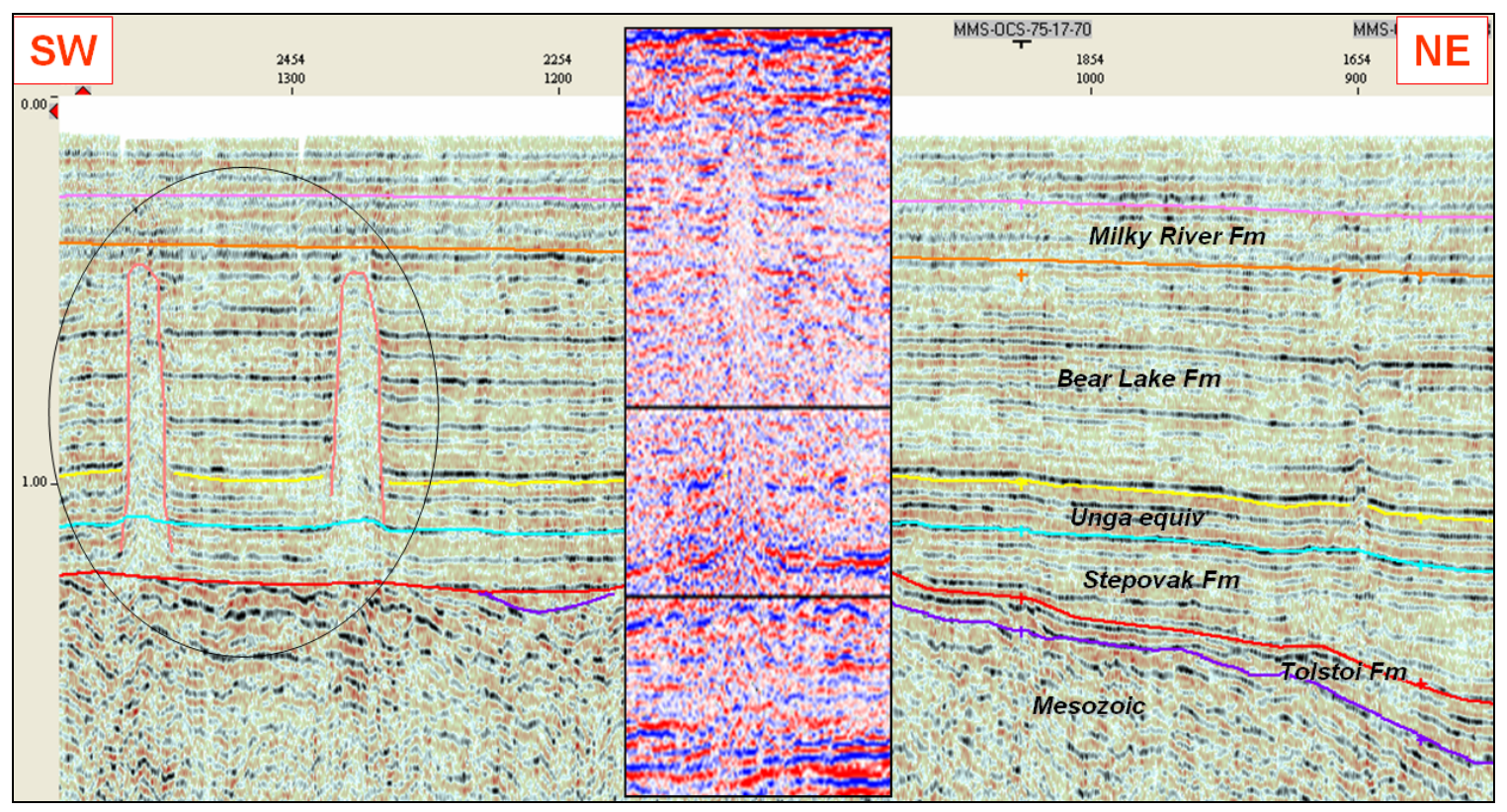

Figure 4.9. Southwest end of line 75-17-03, on westward offshore extension of Black Hills Uplift, where acoustic anomalies (possible gas chimneys?) cross-cut upper Stepovak through Bear Lake succession, unconformably overlying reflective, probable Mesozoic strata. Inset figure at same vertical time scale shows similar geometries in seismic gas chimney from North Sea dataset (www.dgb-group.com). 


\section{$\underline{\text { References Cited }}$}

Beikman, H.M., 1980, Geologic Map of Alaska: U.S. Geological Survey, 1 sheet, scale 1:2,500,000.

Blodgett, R.B., 2005, Observations on Mesozoic fossils and stratigraphy during field investigations of the northern Alaska Peninsula (Puale Bay, Wide Bay, and Lake Becharof Region) by the ADGGS/ADOG, May 24-June 4, 2004 (in preparation).

Brockway, R.G., Alexander, B., Day, P.D., Lyle, W.M., Hiles, R., Decker, W.M., Polski, W., and Reed, B.L., 1975, Bristol Bay region, stratigraphic correlation section, southwest Alaska: Anchorage, Alaska Geological Society, 1 sheet.

Case, J.E., Detterman, R.L., Wilson, F.H., Chuchel, B.A., and Yount, M.E., 1988, Maps showing aeromagnetic survey and geologic interpretation of parts of the Ugashik and Karluk quadrangles, Alaska: U.S. Geological Survey Miscellaneous Field Studies Map MF-1539-D, 12 p., 2 sheets, scale 1:250,000.

Dalrymple, R.W., 1992, Tidal depositional systems, in Walker R.G., and James, N.P., eds., Facies models: Geological Association of Canada, 454 p.

Decker, P.L., 1990, Style and mechanics of liquefaction-related deformation, lower Absaroka Volcanic Supergroup (Eocene), Wyoming: Geological Society of America Special Paper 240, 71 p, 8 plates.

Detterman, R.L., 1990, Stratigraphic correlation and interpretation of exploratory wells, Alaska Peninsula, U.S. Geological Survey Open-file Report 90-279, 51 p., 2 plates.

Detterman, R.L., Case, J.E., Miller, J.W., Wilson, F.H., and Yount, M.E., 1996, Stratigraphic framework of the Alaska Peninsula: U.S. Geological Survey Bulletin 1969-A, Geologic Studies on the Alaska Peninsula, 74 p.

Division of Oil \& Gas, 2004, Alaska Peninsula areawide oil and gas lease sale and Bristol Bay basin Exploration License Area, information and data compilation, 3 volume CD-ROM.

Division of Oil \& Gas, 2005, Regional gravity, aeromagnetic, and geologic maps of the Bristol Bay/Alaska Peninsula region, 1 volume mini-CD-ROM.

Galloway, W.E., 1974, Deposition and diagenetic alteration of sandstone in northeast Pacific arc-related basinsImplications for graywacke genesis: Geological Society of America Bulletin, v. 85, p. 379-390.

Harms, J.C., Southard, J.B., and Walker, R.G., 1982, Structures and sequences in clastic rocks: Society of Economic Paleontologists and Mineralogists, Short Course No. 9.

Hatten, C.W., 1971, Petroleum potential of Bristol Bay Basin, Alaska: American Association of Petroleum Geologists Memoir 15, p. 105-108.

Hite, David, 2004, Bristol Bay Native Corporation-Hydrocarbon potential of Native lands in the Bristol Bay area, southern Alaska: BBNC files, Data Set Index No. 774.

Hudson, T., 1986, Plutonism and provenance-Implications for sandstone composition, in Magoon, L.B., ed., Geologic studies of the lower Cook Inlet COST No. 1 well, Alaska Outer Continental Shelf: U.S. Geological Survey Bulletin 1596, p. 55-60.

Kellum, L.B., 1945, Jurassic stratigraphy of Alaska and petroleum exploration in northwest America: Transactions of the New York Academy of Science, ser. 2, v. 7, no. 8, p. 201-209.

Lyle, W.M., Morehouse, J.A., Palmer, I.F., Jr., and Bolm, J.G., 1979, Tertiary formations and associated Mesozoic rocks in the Alaska Peninsula area, Alaska, and their petroleum-reservoir and source-rock potential: Alaska Division of Geological \& Geophysical Surveys Geologic Report 62, 65 p., 19 plates.

Magoon, L.B., and Anders, D.E., 1992, Oil-to-source-rock correlation using carbon-isotopic data and biological marker compounds, Cook Inlet-Alaska Peninsula, Alaska, in Moldowan, J.M., Albrecht, P., and Philip, R.P., eds., Biological markers in sediments and petroleum: Englewood Cliffs, New Jersey, Prentice Hall, 411 p.

Marincovich, L., Jr., 1983, Molluscan paleontology, paleoecology, and north Pacific correlations of the Miocene Tachilni Formation, Alaska Peninsula, Alaska: Bulletin of American Paleontology, v. 84, p. 59-155.

Marincovich, L., Jr., 1988, Miocene mollusks from the lower part of the Bear Lake Formation on Ukolnoi Island, Alaska Peninsula, Alaska: Los Angeles, Natural History Museum of Los Angeles County, California, Contributions in Science, no. 397, p. 1-20. 
Marincovich, L., Jr., and McCoy, S., Jr., 1984, An overview of Paleogene molluscan biostratigraphy and paleoecology of the Gulf of Alaska region: Paleogeography, Paleoclimatology, and Paleoecology, v. 47, p. 91102.

Marlow, M.S., Cooper, A.K., and Fisher, M.A., 1994, Geology of the eastern Bering Sea continental shelf, in Plafker, G., and Berg, H.C., eds., The Geology of Alaska: Boulder, Colorado, Geological Society of America, The Geology of North America, v. G-1, p. 271-284.

McLean, H., 1977, Organic geochemistry, lithology, and paleontology of Tertiary and Mesozoic rocks from wells on the Alaska Peninsula: U.S. Geological Survey Open-File Report 77-813, 63 p.

Mickey, M.B., Haga, H., Boettcher, R.S., and Kling, S.A., 2005, Northwestern Alaska Peninsula—Bristol Bay basin biostratigraphy study (in preparation).

Nilsen, T.H., 1984, Miocene back-arc tidal deposits of the Bear Lake Formation, Alaska Peninsula, in Reed, K.M., and Bartsch-Winkler, S., eds., The United States Geological Survey in Alaska-Accomplishments during 1982: U.S. Geological Survey Circular 939, p. 85-88.

Nilsen, T.H., and Moore, G.W., 1979, Reconnaissance study of Upper Cretaceous to Miocene stratigraphic units and sedimentary facies, Kodiak and adjacent islands, Alaska, with a section on sedimentary petrography by G.R. Winkler: U.S. Geological Survey Professional Paper 1093, 34 p.

Reifenstuhl, R.R., Bailey, Rebecca D., and Finzel, Emily S., 2005, Bristol Bay and Alaska Peninsula 2004: Fieldwork and Sample Analyses Compilation Report: Alaska Division of Geological \& Geophysical Surveys Preliminary Interpretive Report 2005-1, 22 p.

Turner, R.F., (ed.), 1988, Geological and operational summary, North Aleutian Shelf COST No. 1 well, Bering Sea, Alaska: Anchorage, Minerals Management Service Alaska OCS Region, 256 p.

Walker, K.T., McGeary, S.E., and Klemperer, S.L., 2003, Tectonic evolution of the Bristol Bay basin, southeast Bering Sea: Constraints from seismic reflection and potential field data: Tectonics, v. 22, no. 5, p. 19.

White, J.M., 2005, Palynological report on 20 samples of Neogene age, from the Bear Lake Formation, Alaska Peninsula (in preparation).

White, J.M., Age, T.A., Adam, D.P., Leopold, E.B., Liu, G., Jetté, H., and Schweger, C.E., 1997, An 18 million year record of vegetation and climate change in northwestern Canada and Alaska: Tectonic and global climatic correlates: Palaeogeography, Palaeoclimatology, Palaeoecology, v. 130, p. 293-306.

White, J.M., Age, T.A., Adam, D.P., Leopold, E.B., Liu, G., Jetté, H., and Schweger, C.E., 1999, Neogene and Quaternary quantitative palynostratigraphy and paleoclimatology from sections in Yukon and adjacent Northwest Territories and Alaska: Geological Survey of Canada, Bulletin 543, 30 p.

Wilson, F.H., Gaum, W.C., and Herzon, P.L., 1981, Maps and tables showing geochronology and whole-rock geochemistry, Chignik and Sutwik Island quadrangles, Alaska: U.S. Geological Survey Miscellaneous Field Studies Map MF-1053-m, scale 1:250,000.

Wilson, F.H., Detterman, R.L., and DuBois, G.D., 1999, Digital data for geologic framework of the Alaska Peninsula, Southwest Alaska, and the Alaska Peninsular Terrane, U.S. Geological Survey Open-file Report 99317, 41 p., map.

Wisehart, R.M., 1971, Paleoenvironmental analysis of the Bear Lake Formation (upper and middle Miocene), Alaska Peninsula: Los Angeles, Calif., University of California, M.S. thesis, 112 p.

Wolfe, J.A., 1994, An analysis of Neogene climates in Beringia: Palaeogeography, Palaeoclimatology, Palaeoecology, v. 108, p. 207-216.

Worrall, D.M., 1991, Tectonic history of the Bering Sea and the evolution of Tertiary strike-slip basins of the Bering Shelf: Geological Society of America Special Paper 257, 120 p., 1 oversize sheet, 4 plates.

Zachos, J., Pagani, M., Sloan, L., Thomas, E., and Billups, K., 2001, Trends, rhythms, and aberrations in global climate 65 Ma to present: Science, v. 292, p. 686-693. 


\section{Selected References}

Compiled by Karen Clautice and Robert Blodgett

Addicott, W.O., 1971, Tertiary marine mollusks of Alaska; an annotated bibliography: U.S. Geological Survey Bulletin 1343, 30 p.

Alaska Department of Natural Resources and Bristol Bay Native Corporation, 2003, Memorandum of understanding between the Alaska Department of Natural Resources and Bristol Bay Native Corporation to facilitate oil and gas lease sales on State and BBNC land in the Bristol Bay region, 3 p.

Alaska Department of Natural Resources, 1971a, Aeromagnetic map, northwest Nushagak Bay Quadrangle: BBNC files, Data Set Index No. 461, 1 sheet, scale 1:1,250,000.

Alaska Department of Natural Resources, 1971b, Aeromagnetic survey, Goodnews Bay Quadrangle: BBNC files, Data Set Index No. 488, 1 sheet, scale 1:250,000.

Alaska Department of Natural Resources, 1971c, Aeromagnetic survey of Hagemeister Island Quadrangle: 1 sheet, scale 1:250,000.

Alaska Division of Geological \& Geophysical Surveys Staff, 1986, Summary of existing data and potential for commercial hydrocarbon accumulations, Bristol Bay, Alaska: Alaska Division of Geological \& Geophysical Surveys Public Data File 86-13, 20 p.

Alaska Division of Oil \& Gas, 2004a, General information and digital well data-Alaska Peninsula areawide lease sale and Bristol Bay Basin exploration license area: Information and data compilation, v. 1.

Alaska Division of Oil \& Gas, 2004b, Seismic data—Alaska Peninsula areawide lease sale and Bristol Bay basin exploration license area: Information and data compilation, v. 3.

Alaska Division of Oil \& Gas, 2004c, Scanned electric well logs-Alaska Peninsula areawide lease sale and Bristol Bay basin exploration license area: Information and data compilation, v. 2.

Alaska Oil \& Gas Conservation Commission (AOGCC), 2004, Alaska exploratory wells list: httsp://www.state.ak.us.local/akpages/ADMIN/ogc/homeogc.htm

Albanese, M.D. and Goff, K.M., 1987, Petrified wood occurrences in Alaska: Alaska Division of Geological \& Geophysical Surveys Public Data File 87-26, 11 p.

Allaway, W.H., Jr., Detterman, R.L., Miller, J.W., and Magoon, L.B., 1984, Stratigraphic clarification of the Shelikof Formation, Alaska Peninsula, in Stratigraphic notes, 1983: U.S. Geological Survey Bulletin 1537-A, p. A21-A29.

Allaway, W.H., Jr., 1982, Sedimentology and petrography of the Shelikof Formation, Alaska Peninsula: San Jose, California, San Jose State University unpublished M.S. thesis, 81 p.

Allaway, W.H., Jr., and Miller, J.W., 1984, Newly recognized sedimentary environments in the Shelikof Formation, in Coonrad, W.L, and Elliot, R.L., eds., The United States Geological Survey in Alaska: Accomplishments during 1981: U.S. Geological Survey Circular 868, p. 34-37.

Allison, R.C., 1978, Late Oligocene through Pleistocene molluscan faunas in the Gulf of Alaska region: Veliger, v. 21, p. 171-188.

Allison, R.C., and Addicott, R.C., 1976, The North Pacific Miocene record of Mytilus (Plicatomytilus), a new subgenus of Bivalvia: U.S. Geological Survey Professional Paper 962, 22 p.

Amoco, 1979a, High sensitivity magnetometer survey of the Alaska Peninsula, upper half: BBNC files, Data Set Index No. 703, 1 sheet, scale 1:96,000.

Amoco, 1979b, High sensitivity magnetometer survey of the Alaska Peninsula, lower half: BBNC files, Data Set Index No. 704, 1 sheet, scale 1:96,000.

Amoco, 1979c, High sensitivity magnetometer survey of the Alaska Peninsula: BBNC files, Data Set Index No. 771, 1 sheet, scale 1:96,000.

Amoco, 1980, Bouguer gravity map, Bristol Bay: BBNC files, Data Set Index No. 705, 1 sheet, scale 1:250,000.

Amoco, 1982a, Seismic map of shallow unconformity, east and southeast of Egegik Bay, Alaska Peninsula: BBNC files, Data Set Index No. 688, 1 sheet, scale 1:48,000.

Amoco, 1982b, Seismic map of deep unconformity, east and southeast of Egegik Bay, Alaska Peninsula: BBNC files, Data Set Index No. 687, 1 sheet, scale 1:48,000. 
Amoco, 1982c, ANM shotpoints; Bristol Bay, southern peninsula, Egegik Bay: BBNC files, Data Set Index No. 689, 1 sheet, various scales.

Amoco, 1982d, Alaska Peninsula, Bouguer gravity, density 2.67: BBNC files, Data Set Index No. 702, 2 sheets, scale $1: 250,000$.

Amoco, 1983a, Top of unconformity (time-structure); Bristol Bay, southern peninsula, Ugashik: BBNC files, Data Set Index No. 686,1 sheet, scale 1:48,000.

Amoco, 1983b, Deep unconformity; Bristol Bay, southern peninsula, Egegik Bay: BBNC files, Data Set Index No. 687, 1 sheet, scale 1:48,000.

Amoco, 1983c, Shallow unconformity; Bristol Bay, southern peninsula, Egegik Bay: BBNC files, Data Set Index No. 688,1 sheet, scale 1:48,000.

Amoco, 1983d, BBNC southern peninsula, seismic base for gravity and magnetics, base map 3: BBNC files, Data Set Index No. 727, 1 sheet, scale 1:250,000.

Amoco, 1985, Post drilling ppraisal of the Amoco Becharof State No. 1 well: BBNC files, Data Set Index No. 623, $35 \mathrm{p}$.

Atwood, W.W., 1911, Geology and mineral resources of parts of the Alaska Peninsula: U.S. Geological Survey Bulletin 467, 137 p.

Bascle, R., Evans, D., Seidlitz, A., and Borkowske, J., 1987, Alaska Peninsula/Becharof National Wildlife Refuges Oil and gas assessment: Bureau of Land Management.

Beikman, H.M., 1980, Geologic map of Alaska: U.S. Geological Survey, 1 sheet, scale 1:2,500,000.

Bishop, W.C., 1985, History, geology, energy, and mineral resources of Bristol Bay area: Bristol Bay Native Corporation, Internal Report, 145 p.

Blasko, D.P., 1976, Oil and gas seeps in Alaska, Alaska Peninsula, western Gulf of Alaska: U.S. Department of the Interior, Bureau of Mines, Report of Investigations, RI-8122, 78 p.

Blodgett, R.B., Weems, R.E., and Wilson, F.H., 1995, Upper Jurassic reptiles from the Naknek Formation, Alaska Peninsula; A glimpse into Alaska's own "Jurassic Park": Geological Society of America, Abstracts with Programs, v. 27, no. 5, p. 6.

Bristol Bay Native Corporation and Alaska Department of Natural Resources, 2003, Memorandum of understanding between Alaska Department of Natural Resources and Bristol Bay Native Corporation to facilitate oil and gas lease sales on State and BBNC land in the Bristol Bay region: 3 p.

Bristol Bay Native Corporation, 2003, Regional land status map: Bristol Bay Native Corporation, Bristol Environmental \& Engineering Services Corporation, 1 sheet.

Bristol Bay Native Corporation, 2004, Bristol Bay Native Corporation oil and gas files: 5 p.

Burk, C.A., 1965, Geology of the Alaska Peninsula-Island Arc and Continental Margin: The Geological Society of America Memoir 99, 250 p., 3 sheets.

Capps, S.R., 1922, The Cold Bay District, Alaska, U.S. Geological Survey Bulletin 739-C, p. 77-116.

Capps, S.R., 1937, Kodiak and vicinity, Alaska: U.S. Geological Survey Bulletin 868-B, p. 93-134, 1 sheet, scale 1:250,000.

Case, J.E., Detterman, R.L., Wilson, F.H., Chuchel, B.A., and Yount, M.E., 1988, Maps showing aeromagnetic survey and geologic interpretation of parts of the Ugashik and Karluk quadrangles, Alaska: U.S. Geological Survey Miscellaneous Field Studies Map, MF-1539-D, 12 p., 2 sheets, scale 1:250,000.

Citron, G.P, Kay, R.W., Mahlburg Kay, S., Snee, L.W., and Sutter, J.F., 1980, Tectonic significance of Early Oligocene plutonism on Adak Island, central Aleutian Islands, Alaska: Geology, v. 8, p. 375-379.

Connelly, William, and Moore, J.C., 1979, Geologic map of the northwest side of the Kodiak Islands, Alaska: U.S. Geological Survey Miscellaneous Field Studies Map MF-1057, 2 sheets, scales 1:250,000 and 1:63,360. [See USGS Open-File Report 77-382.]

Conwell, C.N., and Triplehorn, D.M., 1978, Herendeen Bay-Chignik coals, southern Alaska Peninsula, Alaska Division of Geological \& Geophysical Surveys Special Report 8, 15 p., 2 sheets.

Csejtey, B., Jr., and St. Aubin, D.R., 1981, Evidence for northwestward thrusting of the Talkeetna Superterrane, and its regional significance; in Albert, N.R.D., and Hudson, T., eds., 1981, The United States Geological Survey in Alaska: Accomplishments During 1979: U.S. Geological Survey Circular 823-B, p. B49-B51. 
Dall, W.H., 1882, Notes on Alaska Cenozoic deposits: American Journal of Science, 3rd Series, v. 24, p. 67-68.

Detterman, R.L., 1990, Stratigraphic correlation and interpretation of exploratory wells, Alaska Peninsula: U.S. Geological Survey Open-File Report 90-279, 51 p., 2 sheets.

Detterman, R.L., and Hartsock, J.K., 1966, Geology of the Iniskin-Tuxedni Region, Alaska: U.S. Geological Survey Professional Paper 512, 78 p.

Detterman, R.L., and Reed, B.L., 1980, Stratigraphy, structure, and economic geology of the Iliamna Quadrangle, Alaska: U. S. Geological Survey Bulletin 1368-B, 86 p., 1 map, scale 1:250,000.

Detterman, R.L., Case, J.E., Church, Stanley E., Frisken, J.G., Wilson, F.H., and Yount, M.E., 1990, The Alaska Mineral Resource Assessment Program; background information to accompany folio of geologic and resource maps of the Ugashik, Bristol Bay, and western part of Karluk quadrangles, Alaska, U.S. Geological Survey Circular, C 1046, 14 p..

Detterman, R.L., 1990, Stratigraphic correlations and interpretations of exploratory wells, Alaska Peninsula, U.S. Geological Survey Open File Report 90-279, 51 p., 2 plates.

Detterman, R.L., and Miller, R.L., 1985, Kaguyak Formation-An Upper Cretaceous flysch deposit, in BartschWinkler, Susan, and Reed, K.M., eds., United States Geological Survey in Alaska: Accomplishments during 1983: U.S. Geological Survey Circular 945, p. 49-51.

Detterman, R.L., Case, J.E., Miller, J.W., Wilson, F.H., and Yount, M.E., 1969, Stratigraphic framework of the Alaska Peninsula, U.S. Geological Survey Bulletin 1969-A, 74 p.

Detterman, R.L., Case, J.E., Wilson, F.H., and Yount, M.E., 1987, Geologic map of the Ugashik, Bristol Bay, and part of Karluk quadrangles, Alaska: U.S. Geological Survey Miscellaneous Investigations Series Map I-1685, scale 1:250,000.

Detterman, R.L., Case, J.E., Wilson, F.H., Yount, M.E., and Allaway, W.H., Jr., 1983, Generalized geologic map of the Ugashik, Bristol Bay, and part of Karluk quadrangles, Alaska: U.S. Geological Survey Miscellaneous Field Studies Map MF-1539-A, scale 1:250,000.

Detterman, R.L., Miller, J.W., and Case, J.E., 1985, Megafossil locality map, checklists, and pre-Quaternary stratigraphic sections of Ugashik, Bristol Bay, and part of Karluk quadrangles, Alaska: U.S. Geological Survey Miscellaneous Field Studies Map MF-1539-B, 3 sheets, scale 1:250,000.

Detterman, R.L., Miller, T.P., Yount, M.E., and Wilson, F.H., 1979, Generalized geologic map of the Chignik and Sutwik Island quadrangles, Alaska: U.S. Geological Survey Miscellaneous Field Studies Map MF-1053-A, 1 sheet, scale 1:250,000.

Detterman, R.L., Miller, T.P., Yount, M.E., and Wilson, F.H., 1981a, Geologic map of the Chignik and Sutwik Island quadrangles, Alaska: U.S. Geological Survey Miscellaneous Investigations Series Map I-1229, 1 sheet, scale 1:250,000.

Detterman, R.L., Miller, T.P., Yount, M.E., and Wilson, F.H., 1981b, Quaternary geologic map of the Chignik and Sutwik Island quadrangles, Alaska: U.S. Geological Survey Miscellaneous Investigations Series Map I-1292, scale 1:250,000.

Detterman, R.L., Wilson, F.H., Yount, M.E., and Miller, T.P., 1987, Quaternary geologic map of the Ugashik, Bristol Bay, and western part of the Karluk quadrangles, Alaska: U.S. Geological Survey Miscellaneous Investigations Series Map I-1801, 1 sheet, scale 1:250,000.

Dow, W.G., 1977, Petroleum source beds on continental slopes and rises, in Geology of Continental Margins: American Association of Petroleum Geologists, Short Course Note Series, No. 6, p. D1-D37.

Eakins, G.R., 1970, A petrified forest on Unga Island, Alaska, Alaska Division of Mines and Geology, Special Report 3, 19 p.

Elder, W.P., and Miller, J.W., 1991, Maps showing fossil localities and checklists of Jurassic and Cretaceous macrofauna of western Alaska: U.S. Geological Survey Open-File Report 91-629, 71 p., 3 sheets, scale 1:500,000.

Fiorillo, A.R. Website showing hadrosaur footprint from Cretaceous rocks at Aniakchak crater: http://www.uaf.edu/seagrant/NewsMedia/01ASJ/09.21.01dinosaur.html

Fischer, P., 1872, Sur quelques fossiles de l'Alaska, rapportés par. M.A. Pinart: Compt. Rendu, v. 75, p. 1784-1786.

Fischer, P., 1875, Sur quelques fossiles de l'Alaska: Voyages a la côte nord-ouest d'Amérique, pt. 1, p. 33-36, pl. A. 
Galloway, W.E., 1974, Deposition and diagenetic alteration of sandstone in northeast Pacific Arc-related basins; Implications for graywacke diagenesis: Geological Society of America Bulletin, v. 85, no. 3, p. 379-390.

Gulf Oil, 1962a, Total magnetic contours, Port Moller area: BBNC files, Data Set Index No. 695, 1 sheet, scale 1” = 8,000 '.

Gulf Oil, 1962b, Gravity meter survey, Port Moller-Port Heiden area, Alaska: BBNC files, Data Set Index No.693, 1 sheet, scale $1 "=8,000$ '.

Gulf Oil, 1964, Port Moller project; Fireweed and Sandy River area, Deep Phantom Horizon \#2: BBNC files, Data Set Index No. 694, 1 sheet, scale 1" = 8,000'.

Gulf Oil, 1969, Port Moller project, Fireweed and Sandy River rea, Deep Phantom Horizon \# 2: Interpretative seismic map, BBNC files, Data Set Index No. 694, 1 sheet, scale 1” = 8,000’.

Hazzard, J.C., 1950, Lower Cretaceous rocks at Cape Kaguyak north of Kukak Bay, Alaska: Science, v. 112, no. 2904, p. 227.

Hazzard, J.C., Borax, Eugene, Bryan, J.J., Shoemaker, R.W., 1950, Cretaceous rocks in the Kamishak Bay area, Cook Inlet, Alaska: Science, v. 112, no. 2904, p. 226-227.

Hite, David, 2004, Bristol Bay Native Corporation-Hydrocarbon potential of Native lands in the Bristol Bay area, southern Alaska: BBNC files, Data Set Index No. 774.

Hoare, J.M. and Coonrad, W.L., 1961a, Geologic map of the Hagemeister Island Quadrangle, Alaska: U.S. Geological Survey Miscellaneous Geologic Investigations, Map I-321, 1 map, scale 1:250,000.

Hoare, J.M., and Coonrad, W.L., 1961b, Geologic map of the Goodnews Quadrangle, Alaska: U.S. Geological Survey Miscellaneous Geologic Investigations, Map I-339, 1 map, scale 1:250,000.

Hoare, J.M., and Coonrad, W.L., 1978, Geologic map of the Goodnews and Hagemeister Island quadrangles region, southwestern Alaska: U.S. Geological Survey Open-File Report 78-9B, 2 sheets, scale 1:250,000.

Hollick, A., 1930, The Upper Cretaceous floras of Alaska: U.S. Geological Survey Professional Paper 182, 185 p.

Hoose, P.J., and Whitney, John, 1980, Map showing selected geologic features of the outer continental shelf, Shelikof Strait, Alaska: U.S. Geological Survey Open-File Report 80-2035, 1 sheet, scale 1:250,000.

Imlay, R.W., 1953, Callovian (Jurassic) ammonites from the United States and Alaska, Part 2. Alaska Peninsula and Cook Inlet regions: U.S. Geological Survey Professional Paper 249-B, p. 41-108, pls. 22-55.

Imlay, R.W., 1975, Stratigraphic distribution and zonation of Jurassic (Callovian) ammonites in southern Alaska: U.S. Geological Survey Professional Paper 836, 28 p.

Imlay, R.W., 1981, Early Jurassic ammonites from Alaska: U.S. Geological Survey Professional Paper 1148, 49 p., 12 plates.

Imlay, R.W., 1984, Early and middle Bajocian (Middle Jurassic) ammonites from southern Alaska: U.S. Geological Survey Professional Paper 1322, 38 p., 2 plates.

Imlay, R.W., and Detterman, R.L., 1977, Some Lower and Middle Jurassic beds in Puale Bay-Alinchak Bay area, Alaska Peninsula: Bulletin of the American Association of Petroleum Geologists, v. 61, p. 607-611.

Iriondo, Alexander, Kunk, M.J., and Wilson, F.H., 2003, 40Ar/39Ar geochronology of igneous rocks in the Taylor Mountains and Dillingham quadrangles in southwest Alaska: U.S. Geological Survey Open-File Report 030421, $32 \mathrm{p}$.

Jones, D.L., and Silberling, N.J., 1979, Mesozoic stratigraphy—-the key to tectonic analysis of southern and central Alaska: U.S. Geological Survey Open-File Report 79-1200, 37 p.

Jones, D.L., and Detterman, R.L., 1966, Cretaceous stratigraphy of the Kamishak Hills, Alaskan Peninsula: U.S. Geological Survey Professional Paper 550-D, p. D53-D58.

Jones, D.L., and Miller, J.W., 1976, Preliminary geologic map of the Alaska Peninsula showing post-Callovian Mesozoic fossil localities: U.S. Geological Survey Open-File Report 76-76, 2 sheets, scale 1:500,000.

Keller, A.S., and Reiser, H.N., 1959, Geology of the Mt. Katmai area, Alaska: U.S. Geological Survey Bulletin 1058-G, p. 261-298, 1 sheet, scale 1:250,000.

Kellum, L.B., 1945, Jurassic stratigraphy of Alaska and petroleum exploration in northwest America: Transactions of the New York Academy of Science, ser. 2, v. 7, no. 8, p. 201-209.

Kellum, L.B., Daviess, S.N., and Swinney, C.M., 1945, Geology and oil possibilities of the southeastern part of the Wide Bay anticline, Alaska, U.S. Geological Survey Preliminary Strategic Map, 17 p. 
Kelly, J.S. and Denman, J.M., 1972, Geological literature on the Alaska Peninsula and adjacent area, Alaska Division of Geological \& Geophysical Surveys Special Report 20, 64 p.

Kennedy, G.C., and Waldron, H.H., 1955, Geology of Pavlof volcano and vicinity, Alaska: U.S. Geological Survey Bulletin 1028-A, p. 1-19, scale 1:100,000.

Knappen, R.S., 1929, Geology and Mineral Resources of the Aniakchak District: U.S. Geological Survey Bulletin 797, p. 161-223.

Lankford, S.M. and Magoon, L.B., 1977, Petrography of the Upper Jurassic through Oligocene sandstones in the Cape Douglas-Kamishak Hills area, lower Cook Inlet in Johnson, K.M., ed., The United States Geological Survey in Alaska, Accomplishments during 1977, U.S. Geological Survey Circular 772-B, p. B60-B62.

Lyle, W.M. and Dobey, P.M., 1974, Geologic evaluation of the Herendeen Bay area, Alaska Peninsula, Alaska Division of Geological \& Geophysical Surveys Alaska Open File Report 48, 22 p., 3 sheets.

Lyle, W.M., and Dobey, P.L., 1973, Geologic and mineral evaluation of the Aniakchak River drainage, Alaska Peninsula, for wild and scenic river study: Alaska Division of Geological \& Geophysical Surveys Open-file Report 26, 21 p., 1 sheet, scale 1:63,360.

Lyle, W.M., Morehouse, J.A., Palmer, I.F., Jr., Bolm, J.G., 1979, Tertiary formations and associated Mesozoic rocks in the Alaska Peninsula area, Alaska, and their petroleum reservoir and source-rock potential, Alaska Division of Geological \& Geophysical Surveys Geologic Report 62, 69 p., 19 sheets.

Mackevett, E.M., Jr., and Plafker, G., 1974, The Border Ranges Fault in southcentral Alaska: U.S. Geological Survey Journal of Research, v. 2, no. 3, p. 323-329.

MacNeil, F.S., 1970, New Pliocene Chlamys (Swiftopecten) and Beringius from the Alaska Peninsula: Nautilus, v. 84, p. 69-74.

MacNeil, F.S., 1973, Marine fossils from the Unga Conglomerate Member of the Bear Lake Formation, Cape Aliaksin, Alaska Peninsula, Alaska: Science Reports of the Tohoku University, Series 2, Geology, no. 6, p. 117-123.

Magoon, L.B., and Anders, D.E., 1992, Oil-to-Source rock correlation using carbon-isotopic data and biological marker compounds, Cook Inlet-Alaska Peninsula, Alaska, in Moldowan, J.M., Albrecht, P., and Philp, R.P., eds., Biological markers in sediments and petroleum: Englewood Cliffs, New Jersey, Prentice Hall, p. 241-274.

Magoon, L.B., Egbert, R.M., and Petering, George, 1978, Upper Jurassic and Cretaceous rocks of the Kamishak Hills-Douglas River area, lower Cook Inlet, in Johnson, K.M., ed., The United States Geological Survey in Alaska: Accomplishments during 1977: U.S. Geological Survey Circular 772-B, p. B57-B59.

Magoon, L.B., Griesbach, F.B., and Egbert, R.M., 1980, Nonmarine Upper Cretaceous rocks, Cook Inlet, Alaska: AAPG Bulletin, v.64, p. 1259-1266.

Magoon, L.B., Adkison, W.L., Chmelik, F.B., Dolton, G.L., Fischer, M.A., Hampton, M.A., Sable, E.G., and Smith, R.A., 1976, Hydrocarbon potential, geologic hazards, and infrastructure for exploration and development of the lower Cook Inlet, Alaska: U.S. Geological Survey Open File Report 76-449, 132 p.

Mancini, E.A., and Deeter, T.M., 1977, Alaska Peninsula Late Cretaceous fore-arc deposition [abs.]: American Association of Petroleum Geologists Bulletin, v. 61, no. 5, p. 811.

Mancini, E.A., Deeter, T.M., and Wingate, F.H., 1978, Upper Cretaceous arc-trench gap sedimentation on the Alaska Peninsula: Geology, v. 6, p. 437-439.

Marincovich, Louie, Jr. (investigator), 1984, Asiatic mollusks in Miocene faunas of the Alaska Peninsula: U.S. Geological Survey Professional Paper 1375, p. 179-180.

Marincovich, Louie, Jr., 1981a, Tyrannoberingius rex, a new genus and species of Miocene gastropod from Alaska: Journal of Paleontology, v. 55, p. 176-179.

Marincovich, Louie, Jr., 1981b, Fossils from the Bear Lake Formation and fossils from the Meshik Formation, in Detterman, R.L., Yount, E., and Case, J., eds., Megafossil localities, checklists, and stratigraphic sections, Chignik and Sutwik Island quadrangles, Alaska: U.S. Geological Survey Miscellaneous Field Studies Map MF103-N, 2 sheets.

Marincovich, Louie, Jr., 1983, Molluscan paleontology, paleoecology, and North Pacific correlations of the Miocene Tachilni Formation, Alaska Peninsula, Alaska: Bulletin of American Paleontology, v. 84, no. 317, p. 59-155, pls. 12-23. 
Marincovich, Louie, Jr., 1988, Miocene mollusks from the lower part of the Bear Lake Formation on Ukolnoi Island, Alaska Peninsula, Alaska: Natural History Museum of Los Angeles County, Contributions to Sciences, no. 397, 20 p.

Marincovich, Louie, Jr., and Kase, Tomoki, 1986, An occurrence of Turritella (Hataiella) sagai in Alaska; implications for the age of the Bear Lake Formation: Bulletin of the National Science Museum [Tokyo, Japan], Series C: Geology and Paleontology, v. 12, no. 2, p. 61-66.

Marincovich, Louie, Jr., and Powell, C.L., II, 1989, Preliminary Tertiary molluscan biostratigraphy of the Alaska Peninsula, southwestern Alaska: U.S. Geological Survey Open-File Report 89-674, 2 sheets.

Marincovich, Louie, Jr., Barinov, K.B., and Oleinik, A.E., 2002, The Astarte (Bivalvia: Astartidae) that document the earliest opening of Bering Strait: Journal of Paleontology, v. 76, p. 239-245.

Martin, G.C., 1921, Preliminary report on petroleum in Alaska: U.S. Geological Survey Bulletin 719.

Martin, G.C., and Katz, F.J., 1912, A geologic reconnaissance of the Iliamna region, Alaska: U.S. Geological Survey Bulletin 485, 138 p.

Martin, G.C., 1916, Triassic rocks of Alaska: Geological Society of America Bulletin, v. 27, p. 685-718.

Martin, G.C., 1924, Correlation and paleogeography of the Cretaceous of Alaska: Pan-Pacific Scientific Congress, Australia, 1923, Proceedings, v. 2, p. 1345-1359.

Martin, G.C., 1926, The Mesozoic stratigraphy of Alaska: U.S. Geological Survey Bulletin 776, 493 p.

McGee, D.L., 1973, Gulf of Alaska petroleum seeps, Alaska Division of Geological \& Geophysical Surveys Alaska Open File Report 32, 9 p.

McLean, Hugh, 1977, Organic geochemistry, lithology, and paleontology of Tertiary and Mesozoic rocks from wells on the Alaska Peninsula: U.S. Geological Survey Open File Report 77-813, 68 p.

McLean, Hugh, 1979, Sandstone petrology: Upper Jurassic Naknek Formation of the Alaska Peninsula and coeval rocks on the Bering Shelf: Journal of Sedimentary Petrology, v. 49, no. 4, p. 1263-1268.

McLean, Hugh, Engelhardt, C.L., and Howell, D.G., 1978, Reconnaissance geologic map of the Cold Bay and False Pass quadrangles, Alaska: U.S. Geological Survey Open-File Report 78-323, 1 sheet, scale 1:250,000.

Merritt, R.D., McGee, D.L., Clough, J.G., and Belowich, M.A., 1987, Coal Atlas of the Alaska Peninsula: Alaska Division of Geological \& Geophysical Surveys, unpublished report.

Merritt, R.D., and McGee, D.L., 1986, Depositional environments and resource potential of Cretaceous coal-bearing strata at Chignik and Herendeen Bay, Alaska Peninsula,:Alaska Division of Geological \& Geophysical Surveys Public Data File 86-72, 44 p.

Merritt, R.D., 1986, Coal resources of the Miocene Unga Conglomerate Member, Bear Lake Formation, Unga Island, Alaska Peninsula: Alaska Division of Geological \& Geophysical Surveys Public Data File 86-69, 33 p.

Mertie, J.B., Jr., 1938, The Nushagak district, Alaska: U.S. Geological Survey Bulletin 903, 96 p., 1 sheet, scale 1:250,000.

Meyer, J.F., Jr., Hansen, J.J., Brizzolara, D.W., Pritchard, M.E., Boggess, P.L., Beaty, C.J., Dirks, K.L., Gumpert, J.D., Bolin, K.A., Gibler, K.I., and Phillipson, E.M., 2004a, Bristol Bay region and Alaska Peninsula oil and gas programs: Alaska Department of Natural Resources, Division of Oil \& Gas, Alaska Peninsula Resource Series, plate 1 of 4.

Meyer, J.F., Jr., Hansen, J.J., Brizzolara, D.W., Pritchard, M.E., Boggess, P.L., Beaty, C.J., Dirks, K.L., Gumpert, J.D., Bolin, K.A., Gibler, K.I., and Phillipson, E.M., 2004b, Oil and gas well data for the Alaska Peninsula and Bristol Bay region: Alaska Department of Natural Resources, Division of Oil \& Gas, Alaska Peninsula Resource Series, plate 3 of 4.

Meyer, J.F., Jr., Hansen, J.J., Brizzolara, D.W., Pritchard, M.E., Boggess, P.L., Beaty, C.J., Dirks, K.L., Gumpert, J.D., Bolin, K.A., Gibler, K.I., and Phillipson, E.M., 2004c, Oil and gas resource map series legend: Alaska Department of Natural Resources, Division of Oil \& Gas, Alaska Peninsula Resource Series, plate 19 of 19, scale 1:250,000.

Meyer, J.F., Jr., Hansen, J.J., Brizzolara, D.W., Pritchard, M.E., Boggess, P.L., Beaty, C.J., Dirks, K.L., Gumpert, J.D., Bolin, K.A., Gibler, K.I., and Phillipson, E.M., 2004d, Seismic data availability for the Bristol Bay region and the Alaska Peninsula: Alaska Department of Natural Resources, Division of Oil \& Gas, Alaska Peninsula Resource Series, plate 4 of 4 . 
Meyer, J.F., Jr., Hansen, J.J., Brizzolara, D.W., Pritchard, M.E., Boggess, P.L., Beaty, C.J., Dirks, K.L., Gumpert, J.D., Bolin, K.A., Gibler, K.I., and Phillipson, E.M., 2004e, Regional geology of the Bristol Bay region and Alaska Peninsula: Alaska Department of Natural Resources, Division of Oil \& Gas, Alaska Peninsula Resource Series, plate 2 of 4 .

Miller, D.J., Payne, T.G., and Gryc, George, 1959, Geology of possible petroleum provinces in Alaska: U.S. Geological Survey Bulletin 1094, 131 p.

Miller, J.W., and Jones, D.L., 1981, A field guide to some common megafossils from post-Callovian Mesozoic rocks of the Alaska Peninsula: U.S. Geological Survey Open-File 81-745, 5 p., 5 pls.

Minerals Management Service (MMS), 1985, Final Environmental Impact Statement, north Aleutian basin sale: U.S. Minerals Management Service report, no. 92, v. 1.

Minerals Management Service, 2000, Undiscovered oil and gas resources, Alaska federal offshore, December 2000 update: Minerals Management Service, 5 p.

Minerals Management Service, 2004, Reappraisal of the north Aleutian shelf planning area: Minerals Management Service (in review, awaiting release by MMS).

Mobil Oil, 1959, Kuskokwim District, Bristol Bay Project: Interpretative seismic map: BBNC files, Data Set Index No. 698, 1 sheet, scale $1 ”=8,000$ '.

Mobil Oil, 1963, Exhibit 4, structure contour map, seismic phantom horizon of probably Late Miocene: BBNC files, Data Set Index No. 697, 1 sheet, scale 1”= 8,000’.

Mojsisovics von Mojsvar, Edmund, 1886, Arktische Triasfaunen; beitraege zur palaeontologischen Charakteristik der arktisch-pacifischen Triasprovinz (Triassic fauna of the Arctic; contribution to the paleontologic characteristics of the Arctic-Pacific Triassic province): Academy of Imperial Sciences St. Petersbourg Mémoires, ser. 7, v. 33, no. 6, 159 p., 20 pl.

Moore, G.W., 1967, Preliminary geologic map of Kodiak Island and vicinity, Alaska: U.S. Geological Survey OpenFile Report 67-161, 1 sheet, scale 1:250,000.

Newton, C.R., 1983, Paleozoogeographic affinities of Norian bivalves from the Wrangellian, Peninsular, and Alexander terranes, northwestern North America, in Stevens, C.H., ed., Pre-Jurassic rocks in western North American Suspect Terranes: Society of Economic Paleontologists and Mineralogists Symposium, p. 37-48.

Newton, C.R., 1990, Triassic-Jurassic boundary section at Puale Bay, Alaska Peninsula; Comparative diversity patterns of skeletal faunas and trace fossils [abstr.]: American Association of Petroleum Geologists Bulletin, v. 74, p. 730.

Nilsen, Tor, 1985, Sedimentology of tidally deposited Miocene Bear Lake Formation, Alaska Peninsula: American Association of Petroleum Geologists, Bulletin, v. 69, no. 4, p. 673.

Palache, Charles, 1904, Geology about Chichagof Cove, Stepovak Bay; with Notes on Popof and Unga Islands (Alaska): Harriman Alaska Expedition, v. 4, p. 69-88.

Palfy, Jozsef, Smith, P.L., Mortensen, J.K., and Friedman, R.M., 1999, Integrated ammonite biochronology and U$\mathrm{Pb}$ geochronometry from a basal Jurassic section in Alaska: Geological Society of America Bulletin, v. 111, p. 1537-1549.

Phillips Petroleum, 1974a, Seismic program maps: BBNC files, Data Set Index No. 422, 1 sheet, scale 1:250,000.

Phillips Petroleum, 1974b, Aeromagnetic interpretation, Chignik area: BBNC files, Data Set Index No. 661, several sheets, multiple scales.

Phillips Petroleum, 1974c, BBNC program map, seismic; Nushagak, Dillingham, Naknek, Ugashik: BBNC files, Data Set Index No. 668, several sheets, various scales.

Phillips Petroleum, 1974d, BBNC program map, seismic; Chignik, Sutwik Island, Stepovak Bay: BBNC files, Data Set Index No. 669, several sheets, various scales.

Phillips Petroleum, 1974e, Chignik Bay and Mitrofinia shot points, BBNC files, Data Set Index No. 712, 1 sheet, scale $1 "=8,000$ '.

Phillips Petroleum, 1974f, Chignik Bay seismic interpretation: BBNC files, Data Set Index No. 711, 1 sheet, scale $1 "=8,000$ '.

Phillips Petroleum, 1974g, Total magnetic intensity, Nushagak Basin, Alaska, BBNC files, Data Set Index No. 744, 1 sheet, scale $1 "=16,000$ '. 
Phillips Petroleum, 1974h, Shot points map, Nushagak Prospect: BBNC files, Data Set Index No. 746, 1 sheet, scale unknown.

Phillips Petroleum, 1975a, Petrology report, Alaska Peninsula-Nushagak area for Bristol Bay Native Corporation: BBNC files, Data Set Index No. 423, 73 p.

Phillips Petroleum, 1975b, Bouguer gravity maps, Mitrofinia area, Alaska: BBNC files, Data Set Index No. 560, 2 sheets, scale 1:63,360.

Pinart, A.L., 1873, Voyage à la côte nord-ouest d'Amérique d'Ounalashka à Kadiak: Bulletin de la Sociéte de Géographie (Paris) Bulletin, ser. 6, v. 6, p. 561-580.

Reifenstuhl, R.R., and McCarthy, Paul, 2004, Petroleum reservoir characterization, source rock potential, fossil fuel resources, and basin analyses, Bristol Bay basin, Alaska: AETDL Quarterly Report, October, 2004, 1 p.

Reifenstuhl, Rocky, Shafer, D.C., Ryherd, T.J., Brizzolara, D.W., and Blodgett, R.B., 2004, Summary of May 25June 4, 2004, Field notes and samples, Puale Bay and Wide Bay areas, Alaska Peninsula: Alaska Division of Geological \& Geophysical Surveys Raw Data File 2004-3, 16 p.

Riehle, J.R., and Detterman, R.L., 1993, Quaternary geologic map of the Mount Katmai Quadrangle and adjacent parts of the Naknek and Afognak quadrangles, Alaska: U.S. Geological Survey Miscellaneous Investigations Series Map I-2032, scale 1:250,000.

Riehle, J.R., Detterman, R.L., Yount, M.E., and Miller, J.W., 1993, Geologic map of the Mt. Katmai Quadrangle and portions of the Naknek and Afognak quadrangles, Alaska: U.S. Geological Survey Miscellaneous Investigations Series Map I-2204, 1 sheet, scale 1:250,000. [See USGS Open-File Report 87-593.]

Riehle, J.R., Wilson, F.H., Shew, Nora, and White, W.H., 1999, Geology of Unga Island and the northwestern part of Popof Island, in Riehle, J.R., ed., A geological and geophysical study of the gold-silver vein systems of Unga Island, southwestern Alaska: U.S. Geological Survey Open-File Report 99-136, CD-ROM release.

Saltus, R.W., Hudson, T.L., Wilson, F.H., 2003, Geophysical identification and geological implications of the southern Alaska magnetic trough: U.S. Geological Survey Open-File Report OF 03-0200, 1 sheet.

Sherwood, K.W. and Craig, J.D., 2001, Prospects for development of Alaska natural gas-A review: Minerals Management Service, Resource Evaluation Office, 135 p.

Sherwood, K.W., Comer, D., and Larson, J., 2003, Review of geologic model for north Aleutian Basin: Minerals Management Service, "Handout”, 25 p.

Sherwood, K.W., Craig, J.D., and Cooke, L.W., 1996, Endowments of undiscovered conventionally recoverable and economically recoverable oil and gas in the Alaska federal offshore: Minerals Management Service, Alaska Outer Continental Shelf Region, OCS Report, MMS 96-0033, 6 p.

Silberling, N.J., 1985, Biogeographic significance of the Upper Triassic bivalve Monotis in circum-Pacific accreted terranes, in Howell, D.G., ed., Tectonostratigraphic terranes of the circum-Pacific region: Circum-Pacific Council for Energy and Mineral Resources Earth Sciences Series No. 1, p. 63-70.

Silberling, N.J., Grant-Mackie, J.A., and Nichols, K.M., 1997, The Late Triassic bivalve Monotis in accreted terranes of Alaska: U.S. Geological Survey Bulletin 2151, 21 p.

Smith, J.P., 1927, Upper Triassic marine invertebrate faunas of North America: U.S. Geological Survey Professional Paper 141, $262 \mathrm{p}$.

Smith, W.R., 1924, The Upper Cretaceous invertebrate fauna of Alaska: Baltimore, Md., The Johns Hopkins University, unpublished Ph.D. dissertation.

Smith, W.R., 1925, The Cold Bay-Katmai district: U.S. Geological Survey Bulletin 773-D, p. 183-207.

Smith, W.R., 1926, Geology and oil developments of the Cold Bay district, Alaska: U.S. Geological Survey Bulletin 783-C, p. 63-88.

Smith, W.R., and Baker, A.A., 1924, The Cold Bay-Katmai district: U.S. Geological Survey Bulletin 755-D, p. 151-218.

Spicer, R.A., 1987, Late Cretaceous floras and terrestrial environment of northern Alaska, in Tailleur, Irv, and Weimer, Paul, eds., Arctic North Slope geology, volume 1, Pacific Section, SEPM, and The Alaska Geological Society, p. 497-512. [Mentions floras from Chignik area, Nelson Island, Nunivak Island, Yukon River, North Slope; see fig. 2 for location.] 
Spurr, J.E., 1900, A reconnaissance in southwestern Alaska in 1898: U.S. Geological Survey 20th annual report, part 7, p. 31-264.

Stanley, G.D., Jr., 1979, Paleoecology, structure, and distribution of Triassic coral buildups in western North America: University of Kansas Paleontological Contributions, v. 65, p. 1-58.

Stanton, T.W., and Martin, G.C., 1905, Mesozoic section on Cook Inlet and Alaska Peninsula: Geological Society of America Bulletin, v. 16, p. 391-410.

Teller, Friedrich, 1886, Die Pelecypod-Fauna von Werchojansk in Ostsiberien: Academy of Imperial Sciences St.Petersbourg Mémoire., ser. 7, v. 33, no. 6.

Thomas, C.P., Doughty, T.C., Faulder, D.D., and Hite, D.M., 2004, South-central Alaska natural gas study: U.S. Department of Energy, National Energy Technology Laboratory-Arctic Energy Office, www.netl.doe.gov , 207 p.

Triplehorn, D.M., 1976, Large kaolinite crystals in the Chignik Formation (Upper Cretaceous), Herendeen Bay, in Short Notes on Alaskan Geology 1976: Alaska Division of Geological \& Geophysical Surveys Geologic Report 51F, p. 23-25.

Troutman, S.M. and Stanley, R.G., 2003, Maps showing sedimentary basins, surface thermal maturity, and indications of petroleum in the Central Alaska Province: U.S. Geological Survey Miscellaneous Field Studies Map MF-2428, 18 p., 1 sheet, scale 1:2,500,000.

Turner, R.F., McCarthy, C.M., Lynch, M.B., Hoose, P.J., Martin, G.C., Larson, J.A., Flett, T.O., Sherwood, K.W., and Adams, A.J., 1988, Geological and operational summary, North Aleutian Shelf COST No. 1 Well, Bering Sea, Alaska: Minerals Management Service, Alaska OCS Region, OCS Report MMS 88-089, 256 p.

U.S. Geological Survey, 1963b, Aeromagnetic map of parts of the Dillingham Quadrangle: BBNC files, Data Set Index No. 727, 1 sheet, scale 1:125,000.

U.S. Geological Survey, 1978, Aeromagnetic map of Chignik and Sutwik Island quadrangles, Alaska: U.S. Geological Survey Open-File Report 78-262, scale 1:250,000.

U.S. Geological Survey, 1995, 1995 National assessment of the United States oil and gas resources: U.S. Geological Survey National Oil and Gas Resource Assessment Team, U.S. Geological Survey Circular 1118, 20 p.

U.S. Geological Survey, 1963a, Aeromagnetic survey of parts of the Ugashik and Karluk quadrangles: BBNC files, Data Set Index No. 526, 1 sheet, scale 1:125,000.

U.S. Geological Survey, 1971a, Aeromagnetic survey, Goodnews area, Bethel A-1 through A-5 quadrangles: BBNC files, Data Set Index No. 528, 1 sheet, scale 1:63,360.

U.S. Geological Survey, 1971b, Aeromagnetic survey, Goodnews area, Hagemeister C-3 through C-7 and D-1 through D-6 quadrangles: BBNC files, Data Set Index No. 529, 11 sheets, scale 1:63,360.

U.S. Geological Survey, 1971c, Aeromagnetic survey, Goodnews area, Goodnews Bay A-1 through A-8, B-1 through B-8, and C-1 through C-8 quadrangles: BBNC files, Data Set Index No. 530, 24 sheets, scale 1:63,360.

U.S. Geological Survey, 1971d, Aeromagnetic survey, Goodnews area, Nushagak Bay B-4, C-4, and D-4 through D8 quadrangles: BBNC files, Data Set Index No. 531, 5 sheets, scale 1:63,360.

U.S. Geological Survey, 1975, Aeromagnetic map of part of the Naknek Quadrangle, Alaska: BBNC files, Data Set Index No. 505, 1 sheet, scale 1:250,000.

U.S. Geological Survey, 1978a, Aeromagnetic maps of the Chignik and Sutwik Island quadrangles: BBNC files, Data Set Index No. 556, 11 sheets, scale 1:63,360.

U.S. Geological Survey, 1978b, Aeromagnetic map of the Chignik and Sutwik Island quadrangles: BBNC files, Data Set Index No. 557, 1 sheet, scale 1:250,000.

Union Oil, 1974, Plate 2B; Seismic project map, Nushagak Project: BBNC files, Data Set Index No. 670, 1 sheet, scale 1:63,360.

Waldron, H.H., 1961, Geologic reconnaissance of Frosty Peak Volcano and vicinity, Alaska: U.S. Geological Survey Bulletin 1028-T, p. 677-708, scale 1:250,000.

Wang, Jason, 1984, Sedimentology of Norian (Late Triassic) cherts and carbonates from the Peninsular Terrane: Puale Bay, Alaska Peninsula: University of Pennsylvania, B.A. Thesis, 124 p. 
Wang, Jason, Newton, C.R., and Dunne, Lorie, 1988, Late Triassic transition from biogenic to arc sedimentation on the Peninsula Terrane, Puale Bay, Alaska Peninsula: Geological Society of America Bulletin, v. 100, p. 14661478.

Weems, Robert E., and Blodgett, Robert B., 1996, The Pliosaurid Megalneusaurus: A newly recognized occurrence in the Upper Jurassic Naknek Formation of the Alaska Peninsula, in Moore, T.E., and Dumoulin, J.A., eds., Geologic studies in Alaska by the U.S. Geological Survey, 1994, U.S. Geological Survey Bulletin 2152, p. 169175.

Westermann, G.E.G, 1964, The ammonite fauna of the Kialagvik Formation at Wide Bay, Alaska Peninsula, Part 1, Lower Bajocian (Aalenian): Bulletins of American Paleontology, v. 47, no. 216, p. 327-503.

Westermann, G.E.G., 1969, The ammonite fauna of the Kialagvik Formation at Wide Bay, Alaska Peninsula, Part 2, Sonninia Sowerbyi Zone (Bajocian): Bulletins of American Paleontology, v. 57, no. 255, p. 4-226.

Westermann, G.E.G., 1978, Alaskinia nom. nov. for Alaskoceras Westermann, 1969 non Miller and Kummel, 1945; Jurassic Ammonitina: Journal of Paleontology, v. 52, p. 604.

White, C.A., 1889, Mesozoic molluscs from the southern coast of the Alaskan Peninsula: U.S. Geological Survey Bulletin 51, p. 64-70, pl. xii-xiv.

Whitney, John, Hoose, P.J., Smith, L.M., and Lybeck, Lynn, 1980, Geologic cross sections of the Outer Continental Shelf of Shelikof Strait, Alaska: U.S. Geological Survey Open-File Report 80-2036, 1 sheet, scale 1:250,000.

Wilson, F.H., 1977, Some plutonic rocks of southwestern Alaska, a data compilation: U.S. Geological Survey OpenFile Report 77-501, 7 p., 4 plates.

Wilson, F.H., 1985, The Meshik arc-An Eocene to earliest Miocene magmatic arc on the Alaska Peninsula: Alaska Division of Geological \& Geophysical Surveys Professional Report 88, 14 p.

Wilson, F.H., 1989, Geologic setting, petrology, and age of Pliocene to Holocene volcanoes of the Stepovak Bay area, western Alaska Peninsula, in Dover, J.H., and Galloway, J.P., eds., Geologic studies in Alaska by the U.S. Geological Survey, 1988: U.S. Geological Survey Bulletin 1903, p. 84-95.

Wilson, F.H., and Coonrad, W.L., in press, The Togiak-Tikchik Complex of southwestern Alaska, a replacement for the Gemuk Group; Stratigraphic nomenclature that has outlived its time: U.S. Geological Survey Scientific Investigations Report, SIR-2005-5019.

Wilson, F.H., and Weber, F.R., 2001, Quaternary geology, Cold Bay and False Pass quadrangles, Alaska Peninsula, in Gough, L.P., and Wilson, F.H., eds., Geologic Studies in Alaska by the U.S. Geological Survey, 1999: U.S. Geological Survey Professional Paper 1633, p. 51-71.

Wilson, F.H., Case, J.E., and Detterman, R.L., 1985, Preliminary description of a Miocene zone of structural complexity in the Port Moller and Stepovak Bay quadrangles, Alaska, in Bartsch-Winkler, Susan, and Reed, K.M., eds., The United States Geological Survey in Alaska, Accomplishments during 1983: U.S. Geological Survey Circular, 945, p. 55-56.

Wilson, F.H., Detterman, R.L., and Case, J.E., 1985, The Alaska Peninsula terrane; a definition: U.S. Geological Survey Open-File Report 85-450, 19 p.

Wilson, F.H., Detterman, R.L., and DuBois, Gregory, 1999, Digital data for the geologic framework of the Alaska Peninsula, Southwest Alaska, and the Alaska Peninsula Terrane: U.S. Geological Survey Open-File Report OFR 99-317; Web release (http://wrgis.wr.usgs.gov/open-file/of99-317/). (Bulletin 1969-B, the printed version, is still not out.)

Wilson, F.H., Gajewski, S.Z., and Angeloni, L.M., 1986, Geological literature of the Alaska Peninsula to 1985: U.S. Geological Survey Open-File Report 86-176, 113 p.

Wilson, F.H., Hudson, T.L., Grybeck, Donald, Stoeser, D.B., Preller, C.C., Bickerstaff, Damon, Labay, Keith, and Miller, M.L., 2003, Preliminary geologic map of the northeast Dillingham Quadrangle (D-1, D-2, C-1, and C2), Alaska: U.S. Geological Survey Open-file Report 03-105, 13 p., scale 1:100,000.

Wilson, F.H., Shew, Nora, DuBois, G.D., and Bie, S.W., 1994, Map and tables showing locations and analytical data for potassium-argon age determinations in the Port Moller, Stepovak Bay, and Simeonof Island quadrangles, Alaska Peninsula: U.S. Geological Survey Miscellaneous Field Studies Map MF-2155-E, 18 p., scale 1:250,000.

Wilson, F.H., Weber, F.R., and Dochat, T.M., 1997, Quaternary geology, and Wilson, F.H., Miller, T.P., and Detterman, R.L., Bedrock geology, both part of, Revised geologic map of the Cold Bay and False Pass 
quadrangles, Alaska Peninsula: U.S. Geological Survey Open-File Report 97-866, 34 p., 1 sheet, scale 1:250,000. (This supercedes the 1992 OFR.)

Wisehart, R.M., 1971, Paleoenvironmental analysis of the Bear Lake Formation, Alaska Peninsula, Alaska: University of California, Los Angeles, Master's Thesis, 112 p.

Yount, M.E., Wilson, F.H., and Miller, J.W., 1985, Newly discovered Holocene volcanic vents, Port Moller and Stepovak Bay quadrangles, Alaska Peninsula, in Bartsch-Winkler, Susan, and Reed, K.M., eds., The United States Geological Survey in Alaska, Accomplishments during 1983: U.S. Geological Survey Circular 945, p. 60-62. 